\title{
Where Failure Is Not the Option - The Military Friendly College: Exploring Student Service Members' and Student Veterans' Perceptions of Climate, Transition and Camaraderie
}

\author{
Leilani Teresa Roberts Browning
}

Follow this and additional works at: https://researchrepository.wvu.edu/etd

\section{Recommended Citation}

Browning, Leilani Teresa Roberts, "Where Failure Is Not the Option - The Military Friendly College: Exploring Student Service Members' and Student Veterans' Perceptions of Climate, Transition and Camaraderie" (2015). Graduate Theses, Dissertations, and Problem Reports. 5270.

https://researchrepository.wvu.edu/etd/5270

This Dissertation is protected by copyright and/or related rights. It has been brought to you by the The Research Repository @ WVU with permission from the rights-holder(s). You are free to use this Dissertation in any way that is permitted by the copyright and related rights legislation that applies to your use. For other uses you must obtain permission from the rights-holder(s) directly, unless additional rights are indicated by a Creative Commons license in the record and/ or on the work itself. This Dissertation has been accepted for inclusion in WVU Graduate Theses, Dissertations, and Problem Reports collection by an authorized administrator of The Research Repository @ WVU.

For more information, please contact researchrepository@mail.wvu.edu. 
Where Failure Is Not the Option - The Military Friendly College: Exploring Student Service Members' and Student Veterans' Perceptions of Climate, Transition and Camaraderie

by

Leilani Teresa Roberts Browning

A dissertation submitted to the

College of Education and Human Services

at West Virginia University

in partial fulfillment of the requirements for the degree of

Doctor of Education

in

Educational Leadership

Ugur Kale, Ph.D., Chair

Patricia Obenauf, Ed.D., Professor Emerita

Betty Mei, Ed.D.

Terence C. Ahern, Ph.D.

Nathan Sorber, Ph.D.

Department of Curriculum and Instruction/Literacy Studies

Morgantown, West Virginia

2015

Keywords: Military Friendly College, Student Veterans, Transition, Camaraderie, Climate

(C) Copyright 2015 Leilani Teresa Roberts Browning 


\begin{abstract}
Where Failure Is Not the Option - The Military Friendly College: Exploring Student Service

Members' and Student Veterans' Perceptions of Climate, Transition and Camaraderie
\end{abstract}

\title{
Leilani Teresa Roberts Browning
}

This research explored the extent to which the campus climate at a military friendly college or university promoted student service members' and student veterans' success of their time to degree in transition following separation from the Armed Forces and the impact of this specific climate on the cultivation of camaraderie in higher education. A mixed methods design incorporated focus group narratives from seven participants $(n=7)$ and information from a webbased survey completed by one hundred and seventy respondents $(n=170)$. Triangulation of qualitative and quantitative data resulted in complementary information and insight of the military friendly school phenomenon at seven colleges and universities. All five branches of the Armed Forces were represented in the sample. Data analysis revealed that support services needed at each campus provoked students' varying endorsement of the military friendly brand in addition to the manifested services and support already in place. Accommodations most requested by the military and veteran community on campus included: a veteran's lounge, priority registration, and credit for courses and training completed during active military commitment and at other higher education institutions. Students reported varied degrees of support during transition and excelled for the most part in academic commitment. Many maintained they would succeed in college performance and graduate. Few participants considered failure of this goal. Some found a supportive network of camaraderie among military and veteran peers when involved in on-campus coursework. Camaraderie among focus group members was attributed as a viable factor toward students' persistence, academic and social support. Survey respondents found that it was a source of encouragement and alleviated student isolation on campus for some. Education benefits offered through the GI Bill most often eased students' college financial obligation. Plausible definitions for military friendly school and camaraderie were presented in the data. 


\section{Dedication}

This scholarly inspiration is dedicated to my Father in Heaven. Thank you for each new day of my life, the time to slay my dragons, and for the blessing of this experience.

I also dedicate this achievement to the men and women in the United States military. I

have always kept in mind that, "Freedom Is Not Free." Thank you for your service to this country. 


\section{Acknowledgments}

I sincerely thank you Dr. Ugur Kale for your guidance, support, patience, and genuine kindness throughout the past two years as the chair of my doctoral committee.

I appreciate your time, patience, and kindness in serving on my doctoral committee Dr. Patricia Obenauf, Dr. Betty Mei, Dr. Terence Ahern, and Dr. Nathan Sorber.

Much appreciation to Dr. Ernest Goeres for his mentorship, wise counsel, and humor in the classroom and to Dr. Richard Walls for your academic wit. Thank you for the memories.

There would not be a doctorate degree in my future if not for the McNair Scholars Program at West Virginia University (WVU). My sincere appreciation to Dr. Betty Mei, a role model of leadership in higher education, mentor and dear friend.

I am grateful for the love and continual encouragement of my sisters, Diana Lehua and Lezlie Laolani. They have always had faith in my ability to persevere and succeed (sometimes against all odds) which was made easier because they were my cheerleaders of support at all times during this life's path.

Adam, Robert, Lorelei, Shawna, Ryan, Alexander, Teija-Rosa, Sonia-Elise, and Samson, if not for you, I would not have been motivated to ascend the highest summit and reach out for the stars.

Mahalo nui loa to my dad John Edward Roberts, mom Maryan Tuione Roberts and my ancestors. We have a new legacy. Peace be with you until we meet again.

My deepest appreciation to my husband Kenny for the strength of our love and the joy of this achievement that will last us a lifetime and then some... 


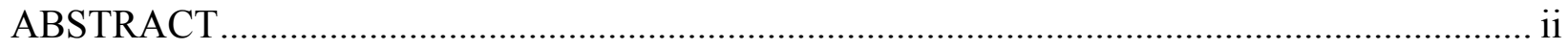

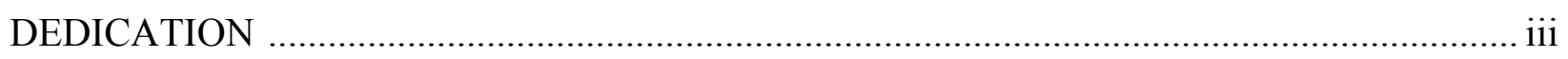

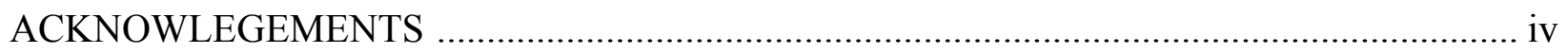

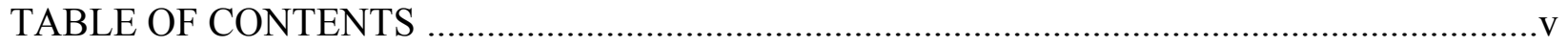

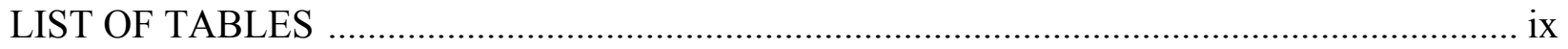

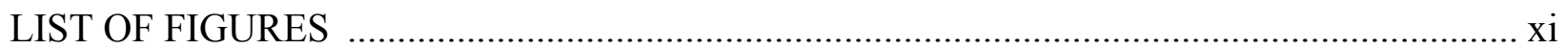

CHAPTER ONE: INTRODUCTION OF THE PROBLEM ...................................................

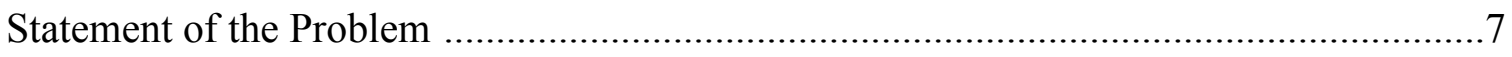

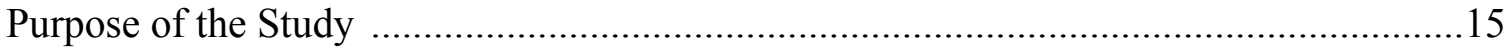

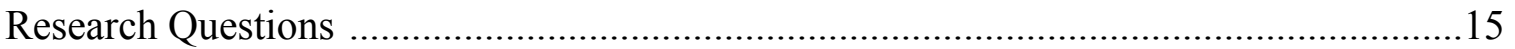

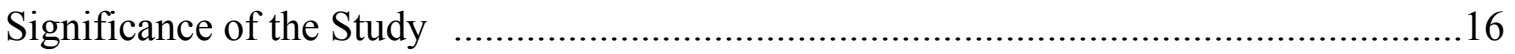

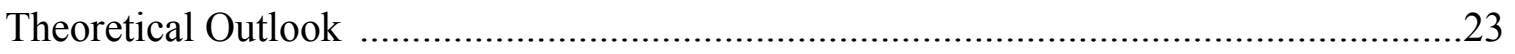

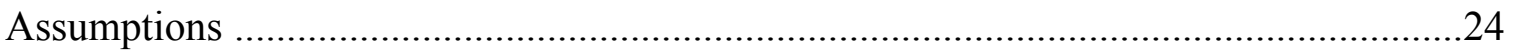

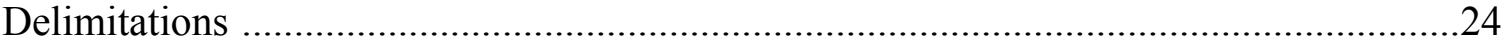

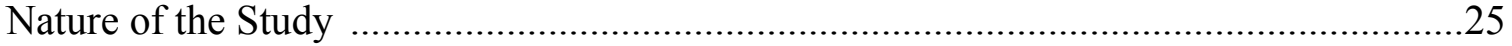

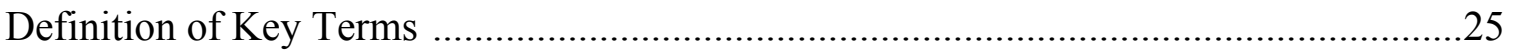

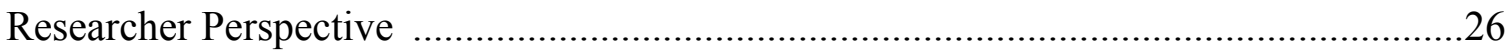

CHAPTER TWO: REVIEW OF RELATED LITERATURE ................................................29

Diversity of Service Members and Veterans .........................................................29

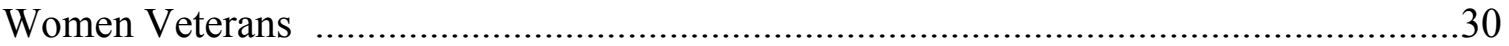

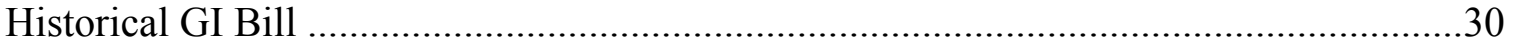

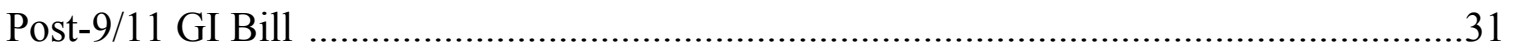

$21^{\text {st }}$ Century Student Service Member and Student Veteran Reintegration .......................32

Student Service Members' and Student Veterans' College Involvement .........................34

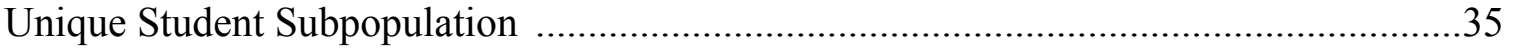

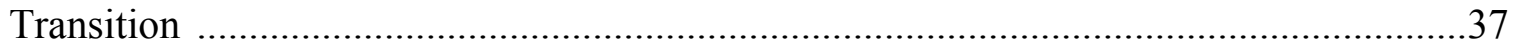

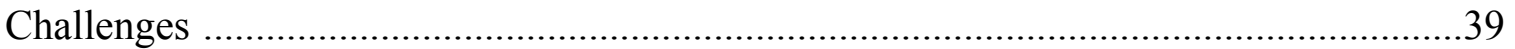

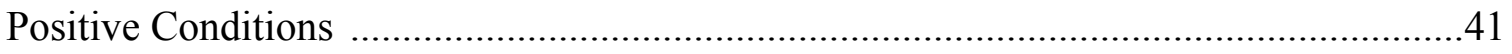

Principles of Excellence and Support .................................................................. 41

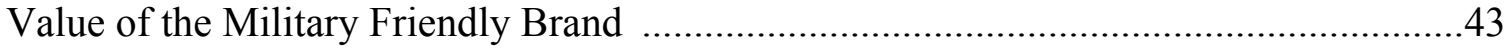




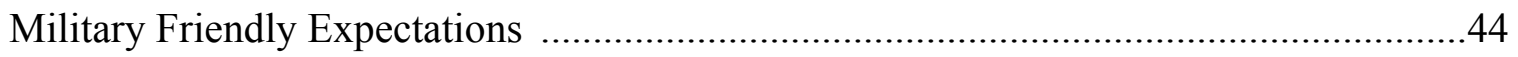

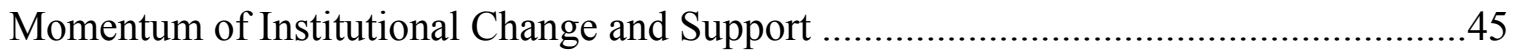

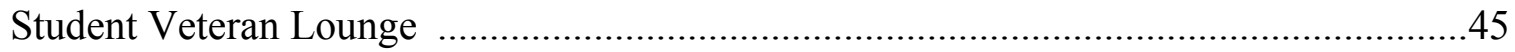

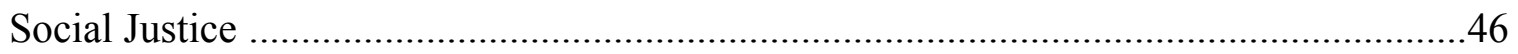

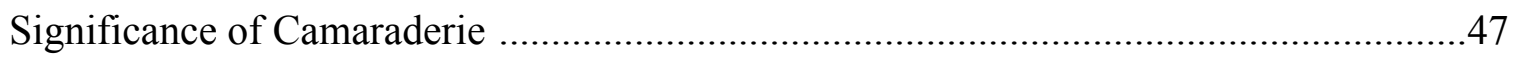

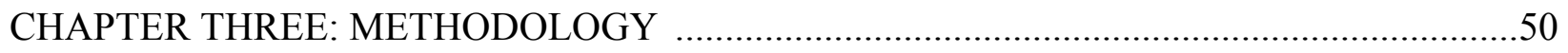

General Recruitment of Participants ......................................................................51

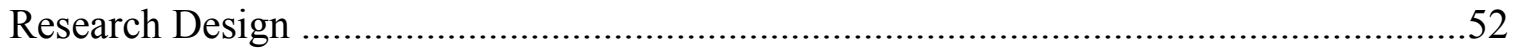

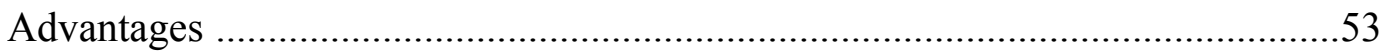

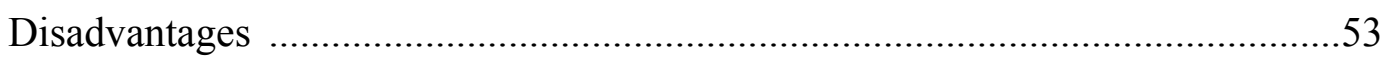

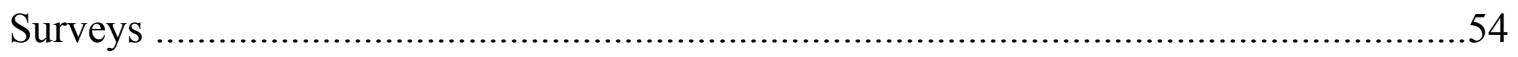

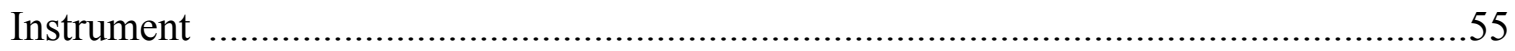

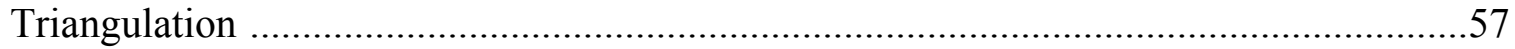

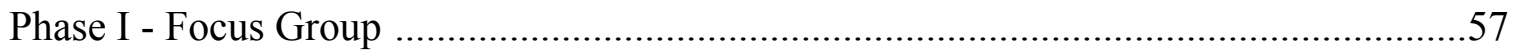

Qualitative Data Analysis .........................................................................6

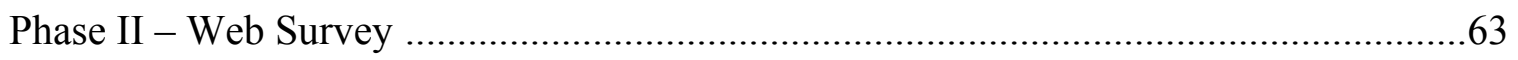

Quantitative Data Analysis ..........................................................................65

Issues of Trust and Anonymity ........................................................................67

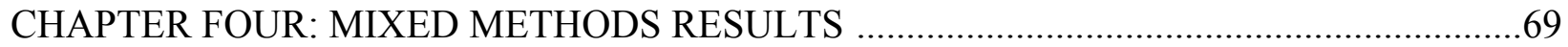

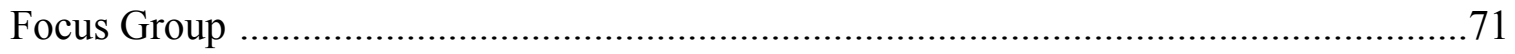

Presentation and Organization of the Findings .........................................................73

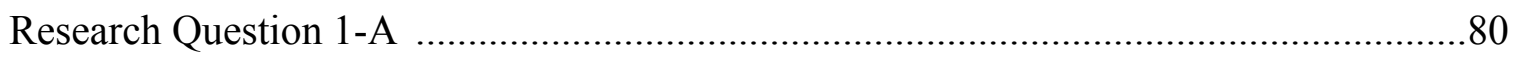

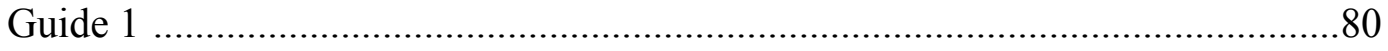

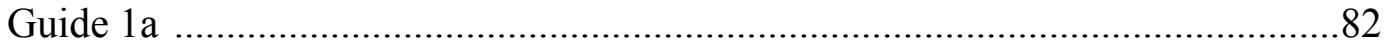

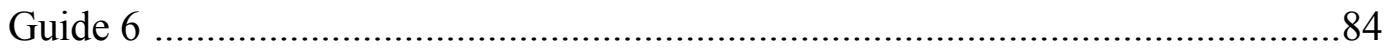

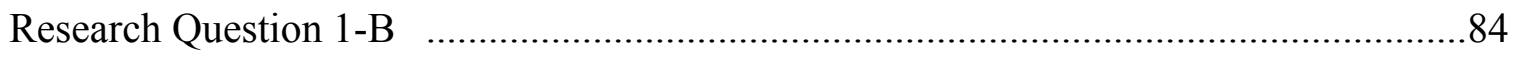

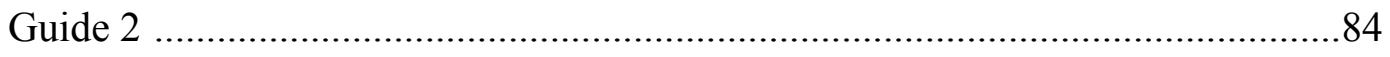

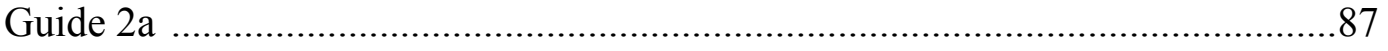

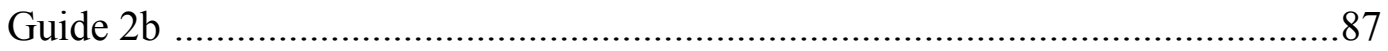

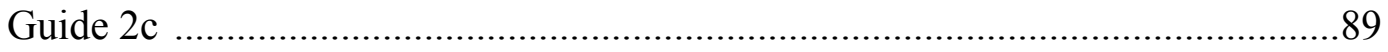

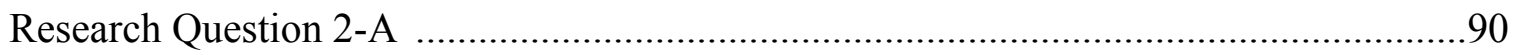

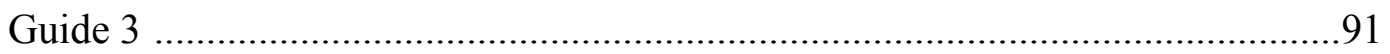




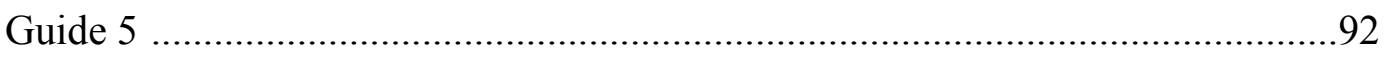

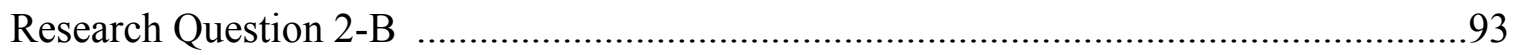

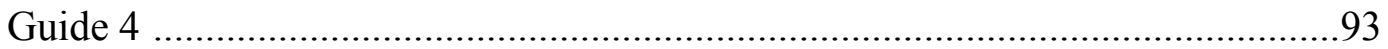

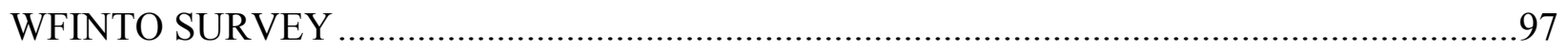

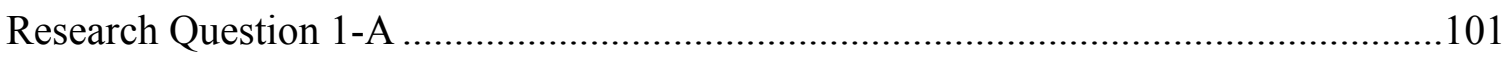

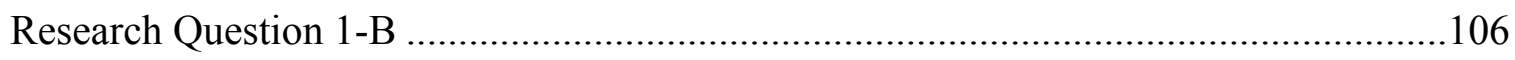

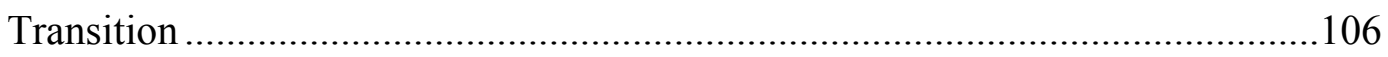

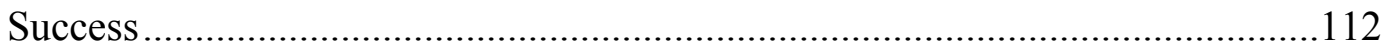

Research Question 2-A .........................................................................................120

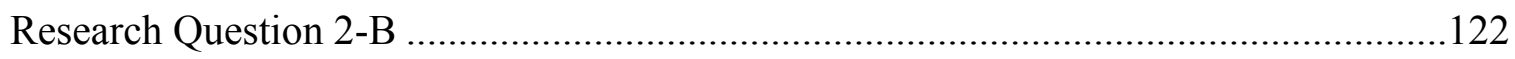

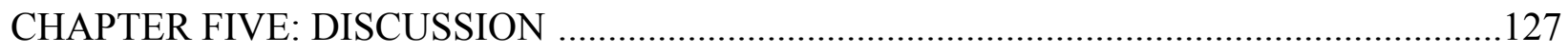

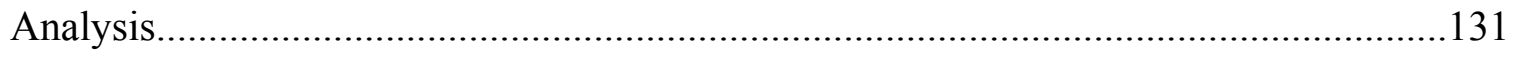

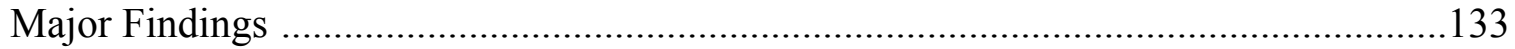

Military Friendly School/Climate ……………………..................................133

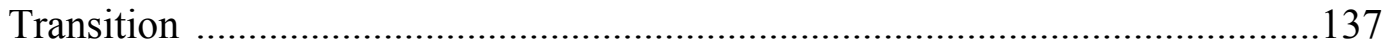

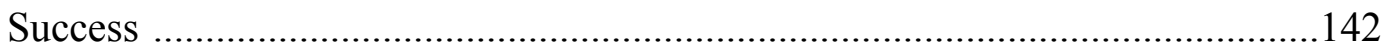

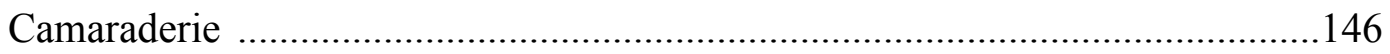

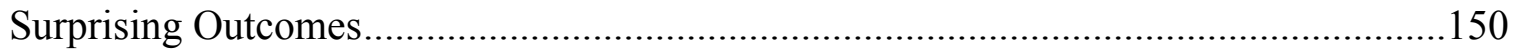

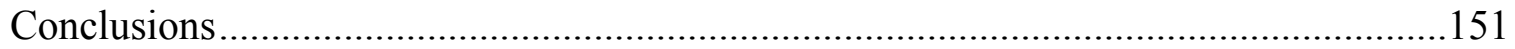

Implications for Action .................................................................................152

Recommendation for Future Research...................................................................153

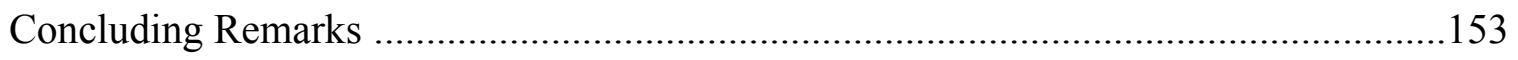

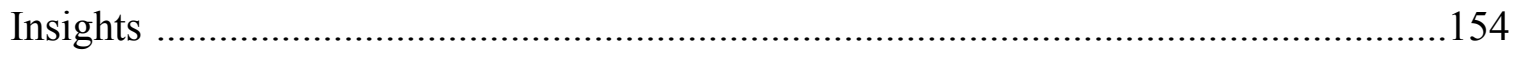

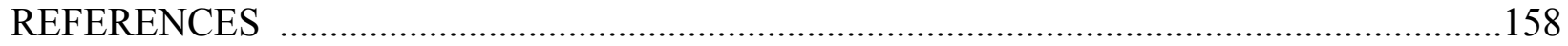

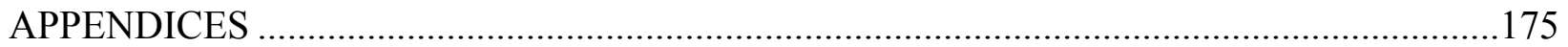

A. WFINTO Military Friendly College/University Survey............................................175

B. Students' Perceptions of Resources/Services/Programs Needed.................................193

C. Students' Expectations of a Military Friendly School ..................................................195

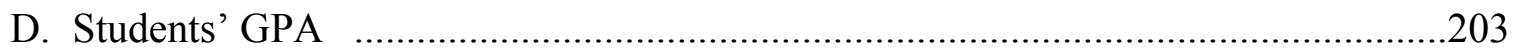

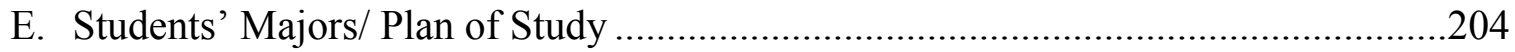

F. Student Service Members' and Students Veterans' Professional Objectives ...........207

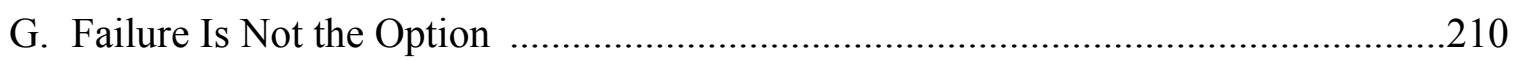




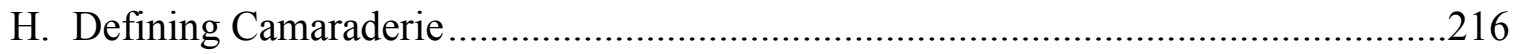

I. Additional Students' Perceptions about Military Friendly Schools/college

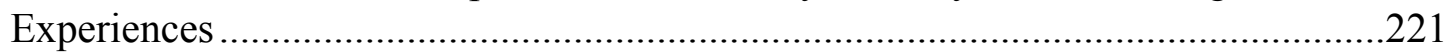




\section{List of Tables}

Table 1. Veterans and Military Students Services: Data from the Soldier to Student II Survey 2012

Table 2. Combined Six Components of the Social Provisions Scale 54

Table 3. Research Questions and Corresponding Focus Group Questions 59

Table 4. State locations of Military Friendly Universities and College 64

Table 5. Survey Questions that Correspond with the Four Research Question 66

Table 6. Military Friendly School 75

Table 7. Transition 76

$\begin{array}{lll}\text { Table 8. Camaraderie/Veterans Lounge } & 78\end{array}$

Table 9. Military Profile: Active-Duty, Mobilized, Deployed Service Members and Veterans 98

Table 10. Diversity of Military Members and Veterans 99

Table 11. Non-traditional Age Categories of Students with Military Experience 100

Table 12. State locations of Military Friendly Universities and Colleges 100

Table 13. Services and Resources Currently Available at Military Friendly

$\begin{array}{ll}\text { Institutions } & 103\end{array}$

Table 14. Service Members' and Veterans' Perceptions of a Military Friendly $\begin{array}{ll}\text { School } & 104\end{array}$

Table 15. Preparing for Transition from the Military to Civilian Life and College 106

Table 16. Time Frame of Military Service to College Enrollment 107

Table 17. Student Service Members' and Student Veterans' Higher Education $\begin{array}{ll}\text { Trajectories } & 108\end{array}$

Table 18. Military Friendly School Transition 111

Table 19. Self-Identification as a Military Member or Veteran on Campus 112 
Table 20. Support among Military and Veteran Peers 121

Table 21. Military and Veteran Peer Relationship on Campus 125 


\section{List of Figures}

Figure 1. Military Members' and Veterans' Transition Route to Higher

Education

Figure 2. Popular websites service members and veterans seek college information 101

Figure 3. Factors of School Selection

102

$\begin{array}{lll}\text { Figure 4. } & \text { Students' Academic Class Status } & 108\end{array}$

Figure 5. Education Benefits Used by Service Members and Veterans in College 109

Figure 6. Delivery of Service Members' and Veterans' Coursework 109

Figure 7. Students' Perception of Military Friendly Schools' Influence on Education

Goal Achievement

Figure 8. Scholarly Activities

Figure 9. Students' Positive Learning Behaviors

Figure 10. Student Life Activities

Figure 11. Number of Credit Hours Taken by Students in Fall 2013 and

Spring 2014

Figure 12. Number of Credit Hours Accrued Toward Graduation

Figure 13. Number of Classes Missed In the Semester

Figure 14. Students' Academic Plans for Fall Semester 2014

Figure 15. Interactions among Military and Veteran Peers on Campus

Figure 16. Bonding among Student Service Members/Student Veteran Peers

Figure 17. Supportive Behaviors among Military and Veteran Peers

Figure 18. Assistance among Military/Veteran Peers 


\section{CHAPTER ONE \\ Introduction of the Problem}

Graduation was expected to be the desired outcome anticipated by most $21^{\text {st }}$ century, contemporary college students. This was also a vision of higher education participation put forth by the President of the United States in 2009 (Advisory Committee on Student Financial Assistance [ACSFA], 2012). The emphasis to achieve this objective could be attributed in large part to the thirty-seven million adults aged 25-64 in this country who had some college education, and ultimately failed to attain their degrees. About 33\% of military service members including veterans were in a similar circumstance according to the U.S. Department of Veterans Affairs (VA) (Northrup, 2013, p. 69).

Student service members and student veterans in higher education had the second chance to prepare for civilian careers and graduate due to the new provisions of the Post-9/11 GI Bill under the Educational Assistance Act of 2008 (Kim \& Cole, 2013; Murphy, 2011). Since the aftermath of World War II, the Servicemen's Readjustment Act, known as the original GI Bill signed into law on June 22, 1944, by President Franklin D. Roosevelt provided military members with benefits and access to higher education with a legacy described by Dickson and Allen (2004) as being "everlasting" throughout the decades (p. 277).

In fiscal year 2011, the VA reported 920,000 military members received education benefits of which more than half used the Post-9/11 GI Bill (Altus, 2013, p. 19). Graduation had become their next important mission to complete (Lang, Harriett, \& Cadet, 2013; Lang \& Powers, 2011; Student Veterans of America, 2013). This was a worthy goal, securing the federal government's attention and support. It initiated renewed and concentrated effort within the U.S. Department of Education to support this objective, and stimulated additional 
government funding and research by various organizations.

The combined efforts of Operation College Promise (OCP), Got Your 6 (GY6) (the Entertainment industry and 30 nonprofit organizations), and the Pat Tillman Foundation (PTF) released results of a 2011 pilot study on student veterans in college (Lang \& Powers, 2011). In 2013, they expanded their inquiry resulting in Completing the Mission II: A Study of Veteran Students' Progress Toward Degree Attainment in the Post 9/11 Era (Lang, Harriett, \& Cadet, 2013). Enrollment had increased significantly from the pilot study's 201 active-duty military students to 453 and 156 veteran students to 370 . The two areas prioritized by these colleges and universities were in marketing and outreach strategies to attract veterans and military personnel, and initiate new programming and services directed at this student subpopulation. This was an important part of $73 \%$ of higher education institutions' long-term strategic plans (Lang, Harriet, \& Cadet, 2013).

A national commitment to increase the number of college degree holders in this country was an undertaking announced in 2009 by President Obama. This expectation was soundly endorsed by higher education administrators promoting the merits of student achievement and success (Advisory Committee on Student Financial Assistance [ACSFA], 2012).

This cause accelerated the number of military and veteran-transition research conducted by colleges and universities, especially those in close proximity to large military bases (Military Family Research Institute [MFRI], 2013). The existence of advertised military friendly colleges and universities also increased substantially since 2001. These institutions emphasized their campus climates with this particular moniker in recruiting students with military experience. 
Student service members and student veterans are considered to be non-traditional student cohorts. This primary characterization was based solely on their years of experiences in the U.S. Armed Services. This differentiated them from the civilian, nontraditional student population on campus (Murphy, 2011). In 2013, the national Student Veterans of America (SVA) Association reported that $85 \%$ of student veterans were 24 or older, $27 \%$ were females, and $47 \%$ had a family. They were unique because military service and wartime involvement had both visible and invisible lingering effects and memories that the general college student population had not experienced (Altus, 2013; Military Family Research Institute [MFRI], 2013; Murphy, 2011).

As with all other American students in higher education, the key factors of access, academic quality, and student success were expectations they held during their transition in campus cultures that were purported to be both student friendly and military friendly, paramount in the persistence of nontraditional learners in academe (Advisory Committee on Student Financial Assistance [ACSFA], 2012; Rogers, 2009). Importantly, being identified as degree completers (significant on a personal level) was also imperative to the United States in terms of the population's educational competitiveness, from an economic stance and global reputation. A formidable goal was at stake in that 2020 was the year the United States was projected to surpass other countries in college completion rating.

A collective endeavor was required of those seeking college degrees and certificates in this country. This had become a national goal, projected by the present administration in the White House that the majority if not all students attending college by 2020 will graduate, exceeding the present $40 \%$ (de Vise, 2011; Northrup, 2013). It was for this reason that higher education reflected an environment with revitalized activity in the structure and 
delivery of supportive services. The aim was to foster students' development and desired learning expectations, inspiring matriculation of civilian student cohorts and transitioning students from military service (Schroeder, 2011).

In current times, becoming student friendly campus climates was anticipated by many higher education experts would help decrease students' academic, social and personal learning barriers. This was the opposite of colleges and universities that have remained historically institutional friendly (Advisory Committee on Student Financial Assistance [ACSFA], 2012; Knefelkamp, Widick, \& Parker, 1978). This novel and alternative perspective encompassed holistic measures, related to the intellectual, emotional, physical, social, vocational, environmental and spiritual well-being of the individual student (Fisher Institute, n.d.; Sanford, 1962, 1966).

Emphasizing student development and success entails progression in higher education coursework, involvement in co-curricular activities and student organizations, in addition to engagement with faculty and peers (Astin, 1984; Evans, Forney, \& Guido-DiBrito, 1998). Thereby, students' challenging experiences and feelings of isolation in the academic realm were mitigated, simultaneously promoting a positive outlook and encouraging persistence and retention; increasing their comfort level with student life in general (Astin, 1999; Rendon, 1994; Sanford, 1962, 1966; Schlossberg, Lynch, \& Chickering, 1989).

It was anticipated in this research that having a college degree in hand, was on the mind of many student service members and student veterans. This credential was a tangible link to their professional goals as many reintegrated into civilian life at their own pace and individual timing. Nearly all higher education immersion of these $21^{\text {st }}$ century warriors had been dictated by troop rotations and withdrawal from warzones. The U.S. involvement in 
fighting the ongoing Global War on Terror, and the military's drawdown attributed to defense budget cuts, had prompted the incentive for service members to transition into college earlier, not waiting until separating from military obligation. Many had opted to use their military education benefits at their first opportunity despite multiple tours of duty or relocations (Altus, 2013; Ricks, 2013). These circumstances had accounted for the increasing appeal of distance education and online learning for those intent on completing their degrees from anywhere in the world (Fodel, 2012, p. 53).

The Armed Forces urged service members to seek college courses in advance of discharge or retirement from active duty. This would allow service personnel ample time to navigate the complexities of the GI Bill administrative process in particular. Military Education Services Specialists held the expectation that undergoing this process as early as possible would be less taxing on the military student (Hobbes, 2012). This was one way of helping to ease the military to college transition frustrations and anxieties reported by student service members and student veterans in previous research studies (Bissell, 2013; Capps, 2011; Carne, 2011; DiRamio, Ackerman, \& Mitchell, 2008; Doenges, 2011; Elliott, Gonzalez, \& Larsen, 2011).

Being admitted on a part time basis or as full time students, military experience had not deterred these men and women from desiring a college education. Instead, it was a motivating factor toward pursuing the knowledge base and skills anticipated to benefit professional roles in their second careers (Murphy, 2011). For many individuals, completing a college degree had not been a goal prior to military enlistment. Serving one's country and having an honorable discharge from the U.S. Armed Forces created a window of opportunity for them to afford college. They had earned the right to the Post- 9/11 GI Bill and other forms of military 
education funding to use at will.

However, caution had been jointly advised by the Armed Forces and U.S. Department of Veterans Affairs' (VA) Education Services Specialists, and military advocate organizations such as Student Veterans of America (SVA), Servicemembers Opportunity Colleges (SOC), and the American Council on Education (ACE) in using military education benefits (Eagle \& Bailey, 2013). They encouraged students to be informed and knowledgeable consumers in choosing higher education institutions touted as military or veteran friendly. Air Force veteran, Dr. Angela Derk Grabuloff, shared this point of view, "It is one thing to say you're veteran friendly, but it's another thing to be." Her higher education trajectory had been at a much touted military friendly university in her state (Grabuloff, personal conversation April, 2013).

The brand used in this exploratory study was military friendly in lieu of veteran friendly. This identified colleges and universities that specifically advertised and recruited students that had current or prior military experiences. This was an academic culture in which student service members expected to enter welcoming and supportive campus climates with programs and curriculum that had been approved by the VA and the Department of Defense (DOD), and use their GI Bill education benefits for tuition assistance without difficulty (Howell, 2012).

These institutions were veteran-centric in offering resources and services, and purported a network of support. With this in mind, and given the lack of empirical research on the military friendly institution phenomenon in higher education, it became important to seriously consider, How military friendly were colleges and universities? To what degree did they support the special needs, interests and success of contemporary student service 
members and student veterans?

\section{Statement of the Problem}

The problem under scrutiny was embedded in the classification of military friendly. The term itself led to speculation that active military personnel and veterans of Iraq, Afghanistan, and other eras were participating in higher education, under a canopy of comprehensive services and resources, often being subsidized with GI Bill benefits or other military education funding (American Council on Education, 2008; Persky, 2011).

The military education market had become a prime source of revenue for colleges and universities dating back to World War II and the original GI Bill (Dickson and Allen, 2004). Ever since August 1, 2009, reauthorization caused billions of dollars more in Post9/11 GI Bill money to support academia throughout the United States. Service members had used education benefit payments that exceeded $\$ 17$ billion since enactment. Benefits had been paid out to 702,576 individuals, and the institutions they attended (Friedman, 2012, para 1; Military Advanced Education, 2012, p. 2). Co-sponsor of the Post-9/11 GI Bill, Senator

Chuck Hagel of Nebraska and later $24^{\text {th }}$ United States Secretary of Defense in 2013, viewed it as a key device toward accessibility of higher learning and a pivotal resource "to reintegrate veterans back into society; [as] education does that about as well as any sphere in our society" (Broad, 2008; Lederman, 2006).

This legislation was evident of the bond that co-existed between higher education and the federal government to diversify educational opportunities, and multiply its positive effect for many without prior avenues to college. Beside other student subpopulations, higher education initiatives were especially directed at the needs, challenges, and barriers that impacted nontraditional students such as service members and student veterans (Advisory 
Committee on Student Financial Assistance [ACSFA], 2012). How they managed and performed within academic settings was important, as they were reflective of the democratic mix found in the U.S. population (U.S. Census Bureau, 2012; U.S. Department of Veterans Affairs, 2012). Military members' diversity was particularly germane in this inquiry.

The informal support network shared among military members and student veterans was an emphasis of the research. The camaraderie relationship had been referenced as a viable component of this subpopulation's coherence on campus (Ackerman, DiRamio, \& Mitchell, 2009; Green, 2012; Murphy, 2011; Naphan, 2011). However, this perspective of camaraderie was limited in connotation. Therefore, a preliminary description was developed by the researcher based on her observation of service members on active duty over the course of years employed at various military bases.

Therefore, camaraderie was characterized as being the intangible bond of friendship, trust, mutual experience, fellowship, and selfless support that existed among those with military experience. A form of kinship and solidarity among individuals to the extent of risking one's life for another in circumstances of risk or wartime involvement.

In past studies, references to camaraderie were fleeting as best, as it was not the central focus analyzed about these students' academic participation, performance, cohesiveness, or interaction among group members pertaining to success and persistence in higher education. Normandin (2010) reported student veterans felt they did not have a support system comparable to what they experienced during military service. They had to face the reality of having an "absent support system" (p. 75). This hindered their interactions with civilians in general and became one of the challenges they encountered in transition.

Student service members and student veterans felt a culture shock during reintegration 
even more than "being in Iraq" (Carne, p.111). This may have led to reported feelings of alienation or isolation. They often recognized each other by the combat boots and military issued backpacks some of their group members used on campus.

Rumann (2010) indicated that some military students felt disconnected to people not having military experience. Their camaraderie was empathetic to the extent they often stayed in touch with military veterans in their communities and those living out of state. Wheeler (2011) pointed out that veterans in college felt that their military peers were often the only ones that could relate to their issues or understood what they were going through. They felt comfortable seeking their advice and discussing personal matters.

Student service members' and student veterans' peer network identified as camaraderie has not been explored within the military friendly framework of colleges and universities. Particularly salient is determining the existence of camaraderie within the military friendly higher education environment (far from the sounds, sights, and smells of war, death, and human suffering) and the risks, if any, perceived by this student subpopulation of their immersion in civilian student life.

Research on student service members and student veterans have particularly highlighted their perceptions of interacting with nonmilitary, traditional age college peers. Their observations of these cohorts in classroom settings had not been interpreted as being positive for the most part, a majority consensus shared by respondents (Carne, 2011; Cate, 2011; Cook, \& Kim, 2009; DiRamio, Ackerman, \& Mitchell, 2008; Doenges, 2011; Elliott, Gonzalez, \& Larsen, 2011; Green, 2012; Murphy, 2011; Normandin, 2010; Rumann, 2010; Wheeler, 2011).

This was in addition to relating to those professors who incorporated their personal 
views and stance on war, the military, and U.S. involvement in the Middle East into classroom lectures and discussions. These situations within the campus climate had been sources of mounting frustration and discomfort for many in the military and student veteran subpopulation. Some have reported feelings of isolation, marginalization, and alienation during the years of transition (Cate, 2011; Murphy, 2011; Naphan, 2011; Rumann, 2010). Their collegiate experiences and interpersonal relationships with civilian peers and faculty had a profound effect on the quality of education perceived by military students.

These areas of concern were relevant to having positive transitions and successful reintegration. Empirical evidence had not been generated in terms of the military friendly institution, which was the primary focus explored in this study. Successful achievement of academic goals, and being influenced by military peers within military friendly climates was an area of research where data had not been forthcoming. Clearly, the value of camaraderie within this specific campus climate had become more pronounced as soldiers became college students. Exploring this phenomenon created new insight, and generated new research questions and hypotheses.

Since fall 2012, 22,000 more American troops sought college degrees. These men and women had returned from the war in the Middle East eager for a positive and quick transition in higher education (Altus, 2013). In order to accommodate their large numbers, administrators and faculty formulated best practice agendas, restructured supportive services and implemented programs to facilitate service members' and student veterans' learning. Therefore, the expectation for those institutions identifying themselves as being military friendly schools had also risen. They shared a certain amount of responsibility to ensure these students capitalized on their GI Bill investment, supported positive and holistic transitions, and 
allowed students' timely entry into the professional milieu.

Student service members' academic experiences began with the higher education institutions they selected. According to Louis F. Martini, the associate vice president of veteran education at Thomas Edison State College, in order to be regarded as a military or veteran friendly school, colleges and universities needed to implement academic policies and decisions that took into account military students' lifestyles. This was a message that should "penetrate all aspects of the institution" instead of a few departments and influenced faculty members to have "an acknowledgement of respect and understanding of these students" (Bissell, 2012, p. 8).

It is important to keep in mind that military friendly is an ambiguous term and meaningful at best to the specific individual as well as his or her perception and needs in college. Student service members' and student veterans' immersive learning within the military friendly campus climate was expected to be synonymous with their persistence. The institution's commitment toward their degree attainment is to be supportive from the topdown impacting policies, initiatives, practices, and mission (American Council on Education [ACE], 2013).

Programming, services, and curriculum were also reflective of the considerations provided to the military and veteran population on campus (Military Family Research Institute [MFRI], 2013). With these conditions present, access to higher education, having tuition and housing paid by GI Bill funding, and opportunities for frequent interactions among military peers being encouraged and reinforced on campus augment students' initial self-concepts of their transition experiences in college (Morreale, 2011).

Other factors vital to this process were the psychological, physical health issues and at- 
risk behaviors that affected military and student veterans' daily routines that diminished their academic performance and impacted student activities. Zinger and Cohen (2010) described the post-deployment challenges some veterans faced and the innumerable changes in their personal lives after returning from war zones and separating from the military as: "coping with PTSD symptoms, depression, physical injury, lack of structure in civilian life, difficulties with personal relationships and social functioning." Many found it especially challenging being the receptacle for negative public opinion against the war. Some were uncomfortable with the reverence they experienced by civilians. Others resorted to using "maladaptive coping mechanisms ...observed the shifting of their sense of self, the world, and personal goals.” (pp. 42-43)

The reintegration process for some had become associated with emotional highs and lows that manifested in "self-destructive behaviors, reliance on alcohol or drugs, chain smoking, uncontrollable anger, instances of rage, bouts of sleeplessness and blackouts, trouble with the law and time spent in jail." One participant in the Zing and Cohen (2010) study whose access to higher education was supported by the GI Bill expressed his uncertainty about transitioning in college, "My biggest fear is the fear of failure....not being successful” (pp. 42-45).

A student organization that promoted advocacy and peer group support of those with military experience were the over 1,100 Student Veteran Chapters linked to students and alumni through in-person or virtual connections. They are affiliated with colleges and universities in the U.S. and abroad, assembled under the national Student Veterans of America (SVA) umbrella (Altus, 2013, p. 19; Student Veterans of America, 2015).

The informal support system of a California SVA chapter was one area of focus 
examined by Cate (2011). His findings did not indicate research participants' reasons for their low attendance (32\%) at student veterans' chapter meetings. This was an indicator that this peer group's interaction and "sense of camaraderie" remained a challenge within the context of higher education student involvement and engagement.

This exploratory scrutiny of military friendly campus climates was important as it impacted the increasing military student subpopulation taking classes at many higher education institutions. Also noteworthy, they are nontraditional students whose academic interests have been delayed by military service or inspired by the same. The years of military experience especially during wartime was a validating factor as to why research was needed to be aligned specifically to these students' interests and issues without being clustered in with other nontraditional student populations in general (Murphy, 2011).

The information gleaned from this study demonstrated to some degree the value of the military friendly brand in the development of student success; and served to inform future active military and student veteran consumers as to the quality of transitional support afforded at colleges and universities. The research discerned to some degree whether student service members were able to thrive and easily mitigate education related adjustments at identified military friendly schools. These institutions extoled their advantages in advertising resources and institutional support tailored for active-military personnel and veterans. They supposedly aligned with students' academic visions of success, higher learning interests, and future career outlook.

Past research on student service members and student veterans have not targeted colleges and universities that explicitly promoted the military friendly brand. For example, data from the 2012 National Survey of Student Engagement (NSSE) of 584 four-year universities 
was supplemented by the Student Veterans/Service Members' Engagement in College and University Life and Education research of 2,505 student service members at 132 institutions in 2013 (Kim\& Cole, 2013). Many of these schools had initiated additional supportive measures for military undergraduates since the Post-9/11 GI Bill took effect. It was not determined in the analyses whether any of the schools were identified as being military friendly. Kim and Cole (2013) highlighted these students' perceptions of reintegration in higher education. Their engagement within the campus climate, preferences, and time allocated for various aspects of student life were linked in part to the demographics of their subgroup (pp. 1-4). This was further constrained by the dynamics of their lives and relationships with others beyond the academic environment.

The cohorts of student service members and student veterans were found to be older (age 25 and over) and racially/ethnically/culturally diverse, more likely to be males, and first in their families attending college (62\%) compared to civilian peers (43\%). A key finding of the NSSE data indicated that they tended to be selective in any involvement pertaining to student life. This included experiential learning (internships, practicums, learning communities, study abroad opportunities, community service), academics, and co-curricular activities "that are not essential for success" or pertaining to coursework. These students spent about ten hours per week studying and had put in more class preparation (70\%) than nonveteran students (65\%). On the other hand, they were less likely to work with other students on assignments outside of class (49\%) compared to $57 \%$ of civilian peers (Kim \& Cook, 2013, pp. 1- 4).

Despite the restructuring of institutional programming and curriculum at many colleges and universities in order to meet the most basic transition needs of their student group, respondents only singled out the "high quality" interactions they experienced with 
administrative personnel (Kim \& Cole, 2013, pp. 17-18). Importantly, student service members and student veterans shared a common perspective found in both research studies; that they generally felt not supported in college. This was a sense of disconnect or disengagement alluded to by Kim and Cole (2013), "In the end, efforts to create a better infrastructure supporting veterans and service members are ineffective if they do not perceive the intended benefits" (p. 5).

This research presented an introductory lens into the military friendly phenomenon in higher education. The value of gaining insight of contemporary student service members' and student veterans' perceptions during their college immersion acknowledged their growing presence in academe and the prominence of their academic needs and concerns within this culture. Equally important, the researcher developed awareness of those factors that contributed to success and expedited students' time to degree at military friendly schools.

\section{Purpose of the Study}

The purpose of this study was to explore the degree to which colleges and universities claiming to be military friendly campus climates, supported student service members' and student veterans' transition through their policies, practices, and resources. Also of interest was the exploration of the phenomenon of camaraderie found among student service members and student veterans that evoked feelings of success in higher education within the military friendly parameter.

\section{Research Questions}

RQ1-A: What are student service members' and student veterans' perceptions of their military friendly campus climates? 
RQ1-B: What are student service members' and student veterans' academic success and transition from the Armed Forces to higher education in relation to their perceptions of military friendly campus climates?

RQ2-A: What are student service members' and student veterans' perceptions of camaraderie among military peers at military friendly campuses?

RQ2-B: What are student service members' and student veterans' academic success and transition from the Armed Forces to higher education in relation to their perceptions of camaraderie among military peers?

\section{Significance of the Study}

The "age of veterans" is once again a phenomenon in the United States (Dungy, 2009). Involvement in the ongoing Global War on Terror has resulted in about $1 \%$ of Americans being at risk of losing their life or experiencing a disability (Bissell, 2013; Wounded Warriors, 2012). Unlike World War II (WWII), the duration of war continued with no definitive ending date since its onset in 2001. Bruce Hoffman of the Edmund A. Walsh School of Foreign Service and Director of the Center for Security Studies at Georgetown University pointed out that "unlike traditional wars [the Global War on Terror]... does not have a clear beginning and an end...it's a war without boundaries" (Raz, 2006).

Wartime involvement for over a decade has caused an increasing number of higher education institutions to strive toward strengthening their relationship with the military community, which includes Active-Duty, Veterans, Dependents, National Guard, and Reserves. The longest war in American history had perpetuated a phenomenon without conscription of an all-volunteer Armed Forces. It involved a cycle of repeated tours in battle zones for many military members, continual enlistment of new service personnel, and the 
separation of thousands of men and women within the military culture.

As these service personnel and veterans returned from the frontlines of battle in the Middle East and other world conflicts, many sought out a route to financial solvency and security in their future civilian careers. The departure from military commitment placed them alongside competitive, well-educated, and technology savvy civilian counterparts. Consistent with civilian job market trends reported by the U.S. Bureau of Labor Statistics (BLS), separation from the Armed Forces may be compounded with an uncertain employment forecast.

The BLS reported in March 2012, that the Current Population Survey (CPS) indicated male Gulf War-era II Veterans, including Reserve and National Guard (18-24 years) who served from September 2001 to the present had an unemployment rate of $20 \%$, higher than non-veterans at $16.4 \%$. Those male veterans age $25-34$ also experienced high unemployment (10.4\%), surpassing the $8.1 \%$ of nonveterans (U.S. Bureau of Labor Statistics, 2012).

The Women Veterans Initiative, a program that specifically identified and addressed Women Veterans' employment issues at the U.S. Department of Labor reported 8.3\% Women Veterans were without jobs in 2012, compared to women non-veterans (7.7\%). This has been a source of particular concern since this number has held steady from the previous year (U.S. Department of Labor, 2013).

In order to leverage their employment marketability while reintegrating into rural hometowns and cities across America, a considerable number of service members and veterans have opted to enroll in colleges and universities. Hershberg (1996) defined the pathway for human capital development as "the education, skill levels, and problem-solving abilities that will enable an individual to be a productive worker in the global economy of the 
twenty-first century," (p.1), in which the college degree can be valued as documentation of professional development for many.

DeGroat and Crowley (2013) contended that higher education offered those who served in the military the "crossover value" needed in civilian careers. The credentials earned through a rigorous program of study at a reputable and accredited institution provided the requisite qualifications for service members without "direct and applicable work experience" (p. 22). Commitment to their plan of study and completion of coursework minimized the risk of failure for those students who prevailed through transition and graduated.

Having insight of these perspectives was best determined by the individual service member and student veteran undergoing the realities of transitioning within the military friendly framework, which prompted an overarching question, What will the report card show about these institutions in general? Recent progress of supportive outreach at colleges and universities was illustrated in the findings of the national Soldier to Student II survey of 690 U.S. higher education institutions (McBain, Kim, Cook, \& Snead, 2012).

Services and programs for military members and student veterans had risen over a three year span from $57 \%$ in 2009 to $62 \%$ in 2012 (Table 1). The research was initiated by the following organizations: American Association of State Colleges and Universities [AASCU], American Council on Education [ACE], National Association of Veterans Program Administrators [NAVPA], and Student Affairs Administrators in Higher Education [NASPA]. 
Table 1

Veterans and Military Students Services: Data from the Soldier to Student II Survey 2012

\begin{tabular}{lcc}
\hline Services & $\mathbf{2 0 0 9}$ & $\mathbf{2 0 0 1 2}$ \\
\hline PTSD Counseling & $16 \%$ & $84 \%$ \\
Staff Trained to Assist with Disabilities & $33 \%$ & $55 \%$ \\
Staff Trained to Assist with Brain & $23 \%$ & $36 \%$ \\
Student Veteran Lounge & $12 \%$ & $47 \%$ \\
Expedient Re-enrollment Process & $0 \%$ & $28 \%$ \\
Transition Assistance & $0 \%$ & $37 \%$ \\
Social Acculturation & $0 \%$ & $0 \%$ \\
Raising Faculty and Staff Sensitivity & $0 \%$ & $0 \%$ \\
\hline
\end{tabular}

The general outlook of these institutions for the most part indicated a collective effort to address crucial areas that have challenged the military subpopulation during transition (DiRamio, Ackerman, \& Mitchell, 2008; Elliott, Gonzalez, \& Larsen, 2011). Other military friendly initiatives had lagged in implementation or had been totally overlooked such as, Transition Assistance and Expedient Reenrollment Process which remained subpar and in need of improvement. Neither Social Acculturation services and Raising Faculty and Staff Sensitivity training have been implemented by any of the 690 institutions during the three years interim. Colleges and universities had the time and were in the position to make ample preparation and formulate their best practice agendas they deemed necessary. It is predictable that more students with military experience will fill classrooms or utilize distance and online learning in years to come (Altus, 2013).

This research was important because it served the public good. Active military members and veterans reflected American society's growing and diverse population. In September 2009, the total veteran population was approximately 23 million in the United States and Puerto Rico (Center for Women Veterans Statistics, 2010). One percent of Americans were in military service at any given time (Bissell, 2012). The stratification of men and women from rural and 
urban communities alike could be found in the Armed Forces.

Their success in higher education elevated opportunities for many individuals coming from low socioeconomic backgrounds, which is crucial in an uncertain economy. Many were first-generation college students whose parents did not achieve a bachelor's degree and some were from underrepresented minority groups. Consequently, positive role models in higher education and society emerged that may inspire generational legacies of future college participation within families from all walks of life.

Furthermore, the data highlighted the significance of camaraderie, acknowledged as peer support in the civilian context. It is strengthened in connotation as it amplified the bonding relationship found among those men and women in college who have served and sacrificed in the name of their country in the U.S. military. The attributes of camaraderie were intangible and inexplicable in variation, commonly referenced as an extraordinary occurrence when individuals were at risk. Camaraderie, has been identified as a phenomenon observed many times over in the theater of war and the lives saved in combat, found among law enforcement personnel protecting the safety and rights of citizens in civilian communities, and reported among those serving as first responders in emergency situations that impacted the general population's well-being (Money et al., 2011).

A projected one million service members were expected to make the transition from the military and reintegrate as private citizens, beginning 2012 to 2015 (Altus, 2013). It was also likely that enrollments at higher education institutions will spiral for student service members and student veterans during this three-year time span. Research studies have increased exponentially since 2001 regarding military members, veterans, dependents, and their families. The data provided insight of the military and veteran community's challenges 
and reflected a sounding board of their concerns.

Higher education institutions such as Kansas State University - Institute for the Health and Security of Military Families ( http://www.militaryfamilies.k-state.edu/), Purdue University - Military Family Research Institute (http://www.mfri.purdue.edu/), University of Southern California - Center for Innovation and Research on Veterans and Military Families (http://www. cir.usc.edu/) and the University of Utah - National Center for Veterans Studies (http:/www.veterans.utah.edu/about), remained continually dedicated to providing empirical justification as to the necessity of studying the experiences and issues impacting the military population in general. As research in this area of focus was prudent to higher education, its value was also of public and national interest.

The researcher expected that the information generated from this study served as a resource of enlightenment for members of the Armed Forces, their dependents, and families. Stakeholders such as Student Veterans of America, U.S. Department of Veterans Affairs, Veterans Upward Bound (a Federal TRIO Program), educators, and the U.S. military's Transition Assistance Program (TAP) had an additional point of reference. Furthermore, it was another source of inspiration for conducting undergraduate research, especially for those service members' dependents who had Transfer of Post-9/11 GI-Bill Benefits to Dependents (TEB) or the Survivors \& Dependents Assistance (DEA) eligibility (U.S. Department of Veterans Affairs, 2012).

The Post-9/11 GI Bill was a hot topic that piqued the general public's interest in recent years. The media and discussion boards on social networking websites had speculated regarding the utility of the $21^{\text {st }}$ Century GI Bill, and in some instances disparagement by some groups of the men and women who had earned the right to use it (Dao, 2013; Student Veterans 
of America [SVA], 2013).

Media sources reported that student veterans had an attrition rate of $88 \%$ during the first year of college. Research data from valid empirical studies had not substantiated this claim. Instead, some clarity to this issue was found in the 2010 National Survey of Veterans (NSV) spearheaded by the VA and supporting data from the U.S. Census Bureau's American Community Survey (ACS). Both reports indicated that the majority of veterans with education benefits completed their degrees or vocational training. The NSV showed an estimated $68 \%$ received certificates or degrees, asserted Cate (2013), research director at the SVA. In spite of some early criticism about misuses of the Post 9/11 GI Bill by some students, these organizations have worked together to deal with these types of issues which had not diminished the value placed on the legacy of the GI Bill.

In part, public scrutiny may have helped to bring about recent action that became advantageous for many. Student service members' and student veterans' staunchest advocate group, the national Student Veterans of America association (SVA), formed a partnership with the Department of Veterans Affairs and the National Student Clearinghouse (NSC), to track veteran students' performance and participation in college related to enrollment, degree completion, and academic outcomes. Development of a national database was evidence that crucial information was needed at present and in the future (Student Veterans of America, 2013).

This student subpopulation has confronted mixed reception on college campuses historically and in current times. Thus, stereotypical views of U.S. military members and veterans during wartime held by some students and faculty were a preview of the challenges and barriers they personally encountered as students. Their student life can be diverse in 
nature compared to traditional students. Collectively as a group, many have reported major personal hurdles they contended with, such as health issues related to Post Traumatic Stress Disorder (PTSD), Traumatic Brain Injury (TBI), depression, and physical disabilities in addition to other difficulties that infused the quality of their transition (Church, 2009).

How these issues and others were managed within the military friendly campus was the premise of this exploratory study. Academic success and degree completion in this specific environment created new perspectives based on the foundation of information provided by a growing list of researchers in the field such as: Ackerman and DiRamio, 2009; Cate, Gerber, and Holmes, 2009; Cook and Kim, 2009; Rumann and Hamrick, 2010, to name a few. Recruitment for America's sons and daughters continued as long as the Global War on Terror was prolonged and the nation was steadfast in preserving democracy and freedom thereby adding to the influx of these students in higher education.

\section{Theoretical Outlook}

Theories by Astin $(1984,1999)$ and Sanford $(1962,1966)$ increased understanding of student service members' and student veterans' perception of transition related to academic success. Astin $(1984,1999)$ offered a developmental theory that supported college students such as military members and veterans to achieve success in their academic endeavors. This began with involvement in student life and activities that expended physical and psychological energy. The more committed students were to achieving their goals, the more they persisted in their studies and ultimately became successful students.

Sanford $(1962,1966)$ suggested the college environment significantly influenced students' development. As a student subpopulation, student service members and student veterans experienced challenges and issues in higher education unknown to most traditional 
students. In order to have successful outcomes occur, they needed to find a balance between the challenges they encountered and the support needed to overcome residual effects of negative experiences in or out of the classroom. It was important to maintain a continual balance of the two which resulted in the student's personal growth. If support outweighed challenges in the student's college life, he or she would not have the opportunity to learn from that experience and develop. A lot of challenge with little support will not only cause frustration, but increase the risk of the student's attrition. Adjusting to changes within the campus climate was easier for those students who were physically and mentally ready to achieve their goals, inspiring their personal and academic development in the process.

\section{Assumptions}

Two assumptions were made by the researcher in the study. Firstly, student service members and student veterans wanted their perceptions known to academicians, researchers, and stakeholders supporting military friendly campus initiatives. Secondly, the researcher's affinity to the military community may be perceived as creating bias in the procedures and interpretation of this exploratory inquiry. Therefore, it was essential that readers understood bias was kept to a minimum as not to hinder the integrity of the research nor diminish the value of participants' college experiences.

\section{Delimitations}

Participants in the research were service members and student veterans completing their AA, BA/BS, or graduate degrees. Those students who were serving in the Students in the Reserves Officer Training Corps (ROTC) and military dependents attending college were not included. College students in ROTC were not considered because the majority of these men and women had not experienced the training and service required of active-duty members 
serving in the U.S. Armed Forces and activated National Guard and Reserves members.

\section{Nature of the Study}

The research aim was to add to the literature and discourse regarding student service members' and student veterans' perception of military friendly collegiate environments and of the nature of their transitions and camaraderie found among peers who have served in the Armed Forces.

A mixed methods approach was conducted to elicit qualitative and quantitative information in an exploratory research design (Clark \& Creswell, 2008). Qualitative data was collected in a focus group comprised of student veterans at a university located in southern West Virginia. Relevant information from the narratives informed the development of the questionnaire which was administered to participants in a web-based survey (Sapsford, 2007). Each institution's Office of Military/Veterans Affairs administrator was contacted either by phone call or email to assess their interest in having their students take part in the study. Equally important, the willingness of each administrator to forward the researcher's recruitment email or research information to students on the military and veteran listserv at each campus was crucial to the successful continuity of the research.

\section{Definition of Key Terms}

Brand:

The name given to a product or service that captures public perceptions (McLaughlin, 2011).

Camaraderie: $\quad$ The strong, intangible bond of friendship, trust, mutual experience, fellowship, and selfless support existing among those having military experience; a form of kinship and solidarity to the extent of risking one's life for another in circumstances of risk or 
wartime involvement.

Campus Climate: $\quad$ Students' attitudes, perceptions, and lived experiences within

the higher education environment (Peterson \& Spencer, 1990).

Student Service Members: Current members of the military. They may be on active-duty or members of the Reserves or National Guard

(Military Family Institute, 2013).

Student Veterans: $\quad$ Anyone who has separated from military service, served under conflict/war conditions or peace time in the military and no longer served, and received an honorable discharge (Military Family Institute, 2013).

\section{Researcher Perspective}

My personal experiences and affiliation to the U.S. military inspired this research. College access and completion of the baccalaureate degree was attributed in large part to education benefits reserved for dependents of disabled veterans, Survivors \& Dependents Educational Assistance Program (DEA) Chapter 35 of Title 38 U.S. Code (U.S. Department of Veterans Affairs, 2012). I would not have fulfilled this goal otherwise.

Inducement to explore the perceptions of students with military background in college stemmed from President John F. Kennedy's inaugural address as $35^{\text {th }}$ president of the United States, delivered on January 20, 1961. In present times, I found excerpts from his speech personally meaningful, as I related his words to the service members and student veterans whose growing presence on campuses across this country inspired normalcy. This was in spite of American society's growing complacency as war continued, military men and women selflessly sacrificed and transformed their lives, and their families' support systems 
were continually tested. In the words of then President Kennedy:

The world is very different now. We dare not forget today that we are the heir of that first revolution. Let the word go forth from this time and place, to friend and foe alike, that the torch has been passed to a new generation of Americans born in this century, tempered by war, disciplined by a hard and bitter peace, proud of our ancient heritageand unwilling to witness or permit the slow undoing of those human rights to which this nation has always been committed, and to which we are committed today at home and around the world...In the long history of the world, only a few generations have been granted the role of defending freedom in its hour of maximum danger. And so, my fellow Americans, ask not what your country can do for you; ask what you can do for your country. (PBS, 2013)

\section{Summary}

Since 2001, the U.S. involvement in the Global War of Terror had also dictated the increasing number of student service members and student veterans enrolled in colleges and universities. They had the option of using the Post-9/11 GI Bill or other military education benefits. As these students sought to make informed choices toward their professional future, some enrolled in schools that were designated as military friendly. This was an environment in academe that supposedly prioritized military and veteran students' successful transition, with an expedient GI Bill process, and strong emphasis on their retention and persistence.

Importantly, graduation would be achievable. These students were part of a national campaign proposed by President Obama and the federal government to increase degree attainment by college students in the U.S. by the year 2020 .

This chapter illustrated the context and background information that was relevant to 
higher education. Chapter Two outlined the literary foundation of past research pertaining to military and veteran college students in general. This included pertinent issues and concerns impacting their higher education trajectory. Chapter Three specified the methodology employed in an exploratory inquiry of students' perceptions of transition within colleges and universities that promoted the phenomena of the military friendly brand in student success relative to sustained academic pursuits, supportive services and the unique presence of camaraderie found among students with military experience. 


\section{CHAPTER TWO}

\section{Review of Related Literature}

The perception that military friendly campus climates reinforced the persistent scholarship of student service members and student veterans in college was a matter of conjecture, as empirical confirmation had not been readily made available in the literature regarding this student subpopulation. This chapter provided a lens to the transition experiences in higher education of military students and veterans that other researchers have described. The areas of concern in this exploratory research and most distinctive of their involvement included: the Diversity of Service Members and Veterans, Historical GI Bill, Post -9/11 GI Bill, $2{ }^{\text {st }}$ Century Military and Student Veteran Reintegration, Service Members' and Student Veterans' College Involvement, Principles of Excellence and Support, Value of the Military Friendly Brand, and the Significance of Camaraderie.

The purpose of this study was to explore the degree to which colleges and universities claiming to be military friendly campus climates supported student service members' and student veterans' transition through their policies, practices, and resources. Also of interest was the exploration of the phenomenon of camaraderie found among service members and student veterans that evoked feelings of success in higher education within the military friendly parameter.

\section{Diversity of Service Members and Veterans}

The typical image of the military soldier has changed visibly since the advent of WWII, and was no longer comprised of only white and black males in uniform which has since been relegated to history books. The inclusion of females and members of many ethnic minority groups had cultivated an unprecedented diversity within military ranks. They were 
identified as members of the United States Armed Forces on active duty or separated from any of the five major branches of the military: Army, Air Force, Coast Guard, Navy, and Marine Corps, which also included Reserve Commands and State National Guard Units. Their tour of service was voluntary at present and no longer conscripted (Daywalt, n.d.).

\section{Women Veterans}

The involvement of women in military service could be traced back to the American Revolution, 237 years ago (Women in Military Service For America Memorial, n.d., para 2). They had been at the forefront of every war and conflict in which the United States was involved.The American Council on Education (2009) reported that women veterans' military service were often hidden or completely left out due to the fact that "they were not asked if they ever served in the U.S. Armed Forces." This was remedied during the 1980 Census as women across the country were asked this important question in which 1.2 million women veterans affirmed their service and were finally credited with helping to secure the freedom of all Americans past and present (U.S. Department of Veterans Affairs, 2007, p. 2-7).

Although an estimated 1.5 million female veterans had served during the Vietnam conflict (U.S. Census Bureau, 2010; U.S. Department of Veterans Affairs, n.d.). Women were not officially assigned to ground combat until 2013 by the United States government (Domi, 2013). The 2010 National Survey of Veterans (NSV) indicated that $19.4 \%$ of women veterans served in combat or war zones (Westat, 2010, p. x).

\section{Historical GI Bill}

The legacy of the transformative Servicemen's Readjustment Act, was signed into law on June 22, 1944, by President Franklin D. Roosevelt. College participation 'for all' was a truism developed soon after WWII ended. Segments of the population such as first generation 
students and minorities at the lower social stratification in the United States were afforded access to college with the passage of the GI Bill (Eckel \& King, 2006). A process of widespread massification democratized higher education as returning service personnel were advantaged by their hard-earned military education benefits. This singular advantage helped to transform the economic environment in postwar America.

Men and women alike achieved their professional aspirations through college performance and degree attainment. By July 25, 1956, as many as 2,232,000 WWII and Korean War veterans had used GI Bill education funding. This outcome was proof that the collaboration between the federal government and higher education had successful outcomes in which " 450,000 engineers, 238,000 teachers, 91,000 scientists, 67,000 doctors, and 22,000 dentists" had gained the credentials to enter the careers they envisioned. Significantly, over a million more people also received some type of college training and had the opportunity to pursue suitable employment (Dickson \& Allen, 2004, p. 276).

Higher education was an environment that not only bridged military and civilian cultures, it became viewed in Western society as a bastion of hope for those seeking empowerment and the social capital needed toward fulfilling careers (Bourdieu, 1983;

Coleman, 1988). Since WWII, the GI Bill was pivotal to a rapidly changing and global employment market, an underlying factor toward military members' growing and noticeable presence at colleges and universities in contemporary times.

\section{Post-9/11 GI Bill}

For many veterans, having an honorable discharge from the military had earned an indirect and precursory path to academe in which they were beneficiaries of a re-energized 2009 GI Bill of Rights. It was a timely and updated version of U.S. historical social legislation 
that reverberated back to WWII veterans' en masse access to postsecondary education (Dickson \& Allen, 2004). The Post 9/11 GI Bill provided the most extensive educational assistance program since the passage of the Servicemen's Readjustment Act of 1944, commonly known as the original GI Bill (American Council on Education, 2009; U.S. Department of Veterans Affairs, 2010).

The VA allocated education benefits to $59.6 \%$ of student veterans attending public institutions, as reported in the 2011 National Center for Education Study (Military Advanced Education, 2013 September, p.13). The lucrative education benefits package authorized access to college and university courses or job training, and certification programs (American Council on Education, 2009; U.S. Department of Veterans Affairs, 2012).

Student service members and student veterans now had the opportunity to be very selective in their choice of college enrollment which ranged from traditional 'brick and mortar' non-profit or for-profit schools, or from more contemporary online, hybrid, or virtual-delivered course offerings. They had the means to either pursue education programs, specialized and onthe-job training, and certification courses. Benefits include tuition, textbooks, living expenses, and monthly stipends (U.S. Department of Veteran Affairs, 2011).

\section{$21^{\text {st }}$ Century Student Service Member and Student Veteran Reintegration}

Student service members' and student veterans' reintegration into civilian life may be difficult at first if they entered college shortly after separating from the military (DiRamio, Ackerman, \& Mitchell, 2008). According to Lederman (2008), these students' adjustment from a military culture may take time since they were leaving a structured, formal, and regimented environment. The process of transitioning from the periphery of minimal civilian engagement during military service into the mainstream of college student life can be daunting (Alvarez, 
2008; DiRamio, Ackerman, \& Mitchell, 2008). The contrast between the two cultures could be overwhelming; effecting a kind of "culture shock" lasting from a few short weeks or extending for months. DiRamio, Ackerman, and Mitchell (2008) suggested six months as being sufficient time for students to make the adjustment from military service to enrolling in college classes.

The first years of college were crucial in determining persistence of this student group. Some needed developmental or refresher courses in Math, English, Science, Literature, and other requisite skills in their major (U.S. Department of Education, 2012). One area of research findings that correlated with others was the degree of interaction and engagement military students and veterans professed to have with traditional-age, civilian peers. The relationships among peer groups were minimal for the most part. The differences in age, life style, experiences in general, and behaviors prompted descriptors such as "uncomfortable, immature, self-centered" in assessment of civilian peers by some military and veteran students (Doenges, 2011; Green, 2012; Livingston, 2009; Murphy, 2011).

In addition to student veterans of which many had been honorably discharged from their military commitment, active-duty personnel, National Guard members and Reservists also took college courses when the opportunity presented itself. Taking advantage of the military's stance to educate those who served their country with access to higher education, many opted to jump-start their professional objectives. One of the rewards of successful performances in completing college level coursework was the impact on the military's assessment of promotions that subsequently influenced active-duty service members' Military Occupation Specialties (MOS) and rank status (Bissell, 2012, October; Military Family Research Institute [MFRI], 2013). 
The American Council on Education study by Buser (2008) of student veterans' perceptions of reintegration offered new insights about their adjustment to college. The focus group results indicated:

* education was a priority, although military commitment took precedence over everything

* civilians did not "know the military"

some needed help with college enrollment

problems with transferring coursework credit

* the need for colleges to accept more military training for credit

* not sufficient information available about military education benefits

* separating from the military was similar to leaving a large support system

* they were not prepared for a culture change (p. 8)

In addition to physical and mental health concerns, other life difficulties such as employment, financial matters and family relationships (spouse, boyfriend /girlfriend, children) strongly influenced the quality of their integration (Buser, 2008, p. 4).

\section{Student Service Members' and Student Veterans' College Involvement}

Student service members' and student veterans' participation in higher education was most often attributed to the GI Bill. It was a hard-earned entitlement especially in circumstances of war. The education benefits had served as an economic buffer to each generation of military students and veterans since the aftermath of World War II. They enrolled in college for the first time as freshmen or continued with course work begun in the military or at other colleges or universities.

These students were advantaged compared to most traditional-age, civilian students 
entering college directly from high school, by having opportunities of leadership development, training, substantive work experience in military service, and the acquisition of some transferable work skills added to their employment portfolio (Military Advanced Education, 2012, October). Those military and veteran students who were first-generation college students had a viable funding resource in the GI Bill. This was in addition to financial aid, scholarships, grants, and fellowships that civilian students often relied upon (U.S. Department of Veterans Affairs, 2010).

In 2007-2008, females comprised $27 \%$ of all military undergraduates (U.S. Census Bureau, 2010). The National Student Clearinghouse (2008) indicated that the most prevalent degrees were held by 5,000 GI Bill beneficiaries in the fields of Nursing, Business Administration, Criminal Justice, General Studies, and Psychology. Military and veteran students attained 47\% Associate degrees and 42\% Bachelor's degrees (American Council on Education, 2009; Department of Education, 2011).

The VA (2011) reported other relevant information regarding these students:

$46 \%$ were undergraduates; $8 \%$ in graduate programs

$34 \%$ received non-college degree training; $12 \%$ enrolled in other educational programs

$59.6 \%$ attended public schools; $25.5 \%$ selected private schools; $14.7 \%$ were taking courses at private non-profit schools

\section{Unique Student Subpopulation}

Compared to traditional and other non-traditional students in higher education, student service members' and student veterans' life experiences prior to college were vastly different in comparison to civilian peers due to the years conditioned by training, responsibilities, and their roles in military service. Not to be overlooked was their exposure to a climate of wartime 
involvement since the events of $9 / 11$. This may be particularly salient in gauging the impact and extent of peer support found among their group in higher education. This understanding may provide clarity to the perception of marginalization and isolation some student service members and student veterans reported about campus life in general (DiRamio, Ackerman, \& Mitchell, 2008). This perception stemmed from their observation and interaction with traditional and nontraditional civilian peers and faculty who had not served in military service, either in war or peacetime (Alvarez, 2008; Lederman, 2008).

Their participation as an underrepresented student subgroup within the college culture had been described as marginal (DiRamio, Ackerman, \& Mitchell, 2008). Many discovered their intention to attend college and simultaneously return to the civilian pace of life was marred by feelings of trepidation at first. New associations and interactions with administrators, staff members and faculty were immensely different in comparison to the chain of command imbedded in military organizations.

Many student service members and student veterans had little understanding or knowledge of the nuances of student life their traditional-age peers often found meaningful and engaged in daily. It was a chain of events in many ways similar to being deployed to a new culture with daily "norms" that placed them in perplexing circumstances fraught with anxiety, challenges and barriers on initial contact.

Enrolling in college is a 'rite of passage' that can often be found to be a daunting task for many civilian, traditional and nontraditional students in general (American Council on Education, 2009). It was also a concern shared by student service members and student veterans (Zing \& Cohen, 2010). Some students reportedly had patterns of learning deficiencies in their early school years, although military service most likely developed their 
learning capabilities and increased their knowledge through military instructional courses and training.

For the most part, they were self-directed adult learners when they entered college for the first time or upon their reentry to complete a previous program of study that was interrupted by military obligation. They were readily focused on preparing for careers in the civilian sector, and wouldn't be compromised in their academic motivations by less than stellar academic records from their past (Rosenbaum, 2001, p. 267). Having GI Bill education benefits had made their goals affordable and attainable. The military market was an economic boost to the colleges and universities these student service members and student veterans attended. Their group's diversity also aligned with the inclusion policies higher education promoted.

Military members' college performance was a hot topic that captured media attention and the general public's interest (Dao, 2013). These students' visibility on campuses across the country had increased substantially as service personnel were discharged from the Armed Forces and sought degrees. At the same time, Academic and Student Affairs'staff had implemented changes at the institutional level to provide transitional support especially at identified military friendly schools. The amount of organizational restructuring varied by schools' impending priorities and budgetary constraints.

\section{Transition}

The community of student service members and student veterans at any given university was around 5\% (Eagle \& Bailey, 2013, October, pp. 21-24). An increasing number of institutions had adopted military or veteran friendly initiatives and policies directed at these nontraditional students. Prioritizing their immediate educational needs and civilian 
employment interests had activated academic communities to upgrade their Student and Academic Services since the onset of war in Iraq and Afghanistan. The American Council on Education Assistant Vice President for Lifelong Learning, James Selbe, pointed out that "a large-scale effort nationwide is taking place in building the capacity to serve veterans, there is still work to do within institutions to improve the veteran experience of transitioning from service to school" (Sewall, 2010).

Some colleges and universities had a long history of delivering education services to students with military experience in the United States and abroad (DeGroat \& Crowley, 2013). They displayed altruistic action on their campuses reinforcing their relationship with the military community. A perusal of student veterans' websites such as: Arizona State University Pat Tillman Veteran Center (https://veterans.asu.edu/), Cleveland State University (http://www.csuohio.edu/studentlife/vikingvets/index.html), Concord University (http://www.concord.edu/veterans); and San Diego State University (http://www.arweb.sdsu.edu/es/veterans) served as exemplary models of higher education institutions that showed initiative, collaborative effort, organizational priority and timely action in addressing many of the needs, issues, and concerns of their military and veteran student population.

Importantly, key administrators, researchers, faculty members, student veterans, grant agencies, and generous benefactors have worked together to create and establish military friendly campus climates that were also student friendly; thereby strengthening further the joint supportive systems of Student Affairs, and Academic Affairs at these institutions (Arizona State University, n.d.; Cleveland State University, 2013; Concord University, n.d.; San Diego State University, 2013). 


\section{Challenges}

Some student service members and student veterans were not fully prepared for the inherent complexities and intensity of transitioning in college (Ackerman, DiRamio, \& Garza, 2009; Cate, 2011; Rea, 2011; Shackelford, 2009). Their capabilities to successfully participate and quickly integrate in higher education may be synonymous with personal issues that influenced their scholarly routines and student life. Some dealt with frequent assaults of pain or discomfort from physical injuries or emotional setbacks and disturbing memories instigated by multiple deployments in war zones. Others encountered unanticipated challenges such as not having the competence and skills required to progress in their desired majors. They belatedly discovered that the gap of years between high school and college affected their selfconfidence with feelings of being inadequately prepared to meet academic rigor.

Skip Gebhart (n.d.) of the Veterans Education and Training Office of the West Virginia Higher Education Policy Commission explained that one of the reasons some of these students experienced difficulties in college was initially due to not selecting the right program of study or school to attend. Personal hindrances in the classroom related to cognitive issues such as attention and concentration problems, test anxiety, math and reading difficulties were prevalent. There was a reluctance to request classroom accommodations when learning problems were encountered.

Those coping with the debilitating effects of Post-Traumatic Stress Disorder (PTSD) experienced substance dependency and mood swings. Traumatic Brain Injury (TBI) and PTSD were identified by Buser (2008) as prolonged conditions that increased the likelihood of other issues that curtailed military and veteran students' activities on and off campus. These conditions were exhibited in poor organization skills, low frustration tolerance, forgetfulness, 
slower processing speeds, visual and auditory problems, difficulty with crowds, reactions to startling noises, sleep problems, and continual physical pain. Some students showed at-risk behaviors or poor coping capacity by being in denial when treatment for health issues were needed.

Behavior problems student veterans indulged in were excessive use of drugs, alcohol and misuse of prescription medication. Serious actions affecting their safety were related to unexpected outbursts of anger or reacting to stressors as though they were still in a combat zone, carrying a weapon (with or without a permit), speeding while driving and making rapid lane changes which critically impacted their lives and that of the general public.

Adaption to both civilian and student life at the same time often posed unanticipated hurdles for many student service members and student veterans. Alvarez (2008) held the outlook that it may not be uncommon for students to become overwhelmed, bewildered, and even frustrated by the variety of choices and rhythms of the college culture.

Navigating administrative processes was a source of frustration for many student service members and student veterans which included: registration problems that prevented them from enrolling in classes on time, delayed GI Bill tuition payments, and schools not allowing for course deferments when re-deployed. This issue was a significant concern of many veteran cohorts transitioning quickly from the battlefield to campus within a brief time span (Herrmann, Raybeck, Wilson, Allen, \& Hopkins, 2008).

Student veterans shared a common frustration when they were denied academic credit for military training or for college courses taken during active-duty (American Council on Education, 2012). This was a serious enough problem for any student, civilian or military. It was an unsettling experience that ultimately led to some student service members and student 
veterans opting to drop out of school for long periods of time or lose interest in college altogether (Georgetown University, n.d.).

\section{Positive Conditions}

The academic environment was not one of adverse conditions, situations, and issues for some service members and student veterans in college. They found that the change in career path from that of military member to civilian enabled them to persist in their studies, take part in alternative career and networking opportunities, and have the opportunity to gain a level of introductory knowledge and skill in their field of interest.

Their leadership skills honed in military service was enhanced when involved in academic and student life activities. Also noteworthy, they gained the perspective that higher education presented an environment where diversity was valued for the most part and where role models existed. Moreover they found that their personal and professional development were benefits linked to academia, motivation, and persistence.

\section{Principles of Excellence and Support}

The President of the United States and other experts at the federal level established the Administration's Principles of Excellence on April 27, 2012, which was by Executive Order 13607 (Presidential Documents, 2012). The federal government's aim was to protect and support military and veterans students and their families from schools having "dishonest recruiting and predatory practices" (Baker, 2013, para 5). As a follow up, the Administration in 2013 announced the 8 Keys to Success, developed with input from over one hundred educators, the Department of Education (ED) and the Department of Veterans Affairs (VA).

The eight very specific guidelines for higher education institutions to streamline 
support of student service members and student veterans were suggested in the following ways (Banker, 2013, para 2):

1. Create a culture of trust and connectedness across the campus community to promote well-being and success for veterans.

2. Ensure consistent and sustained support from campus leadership.

3. Implement an early alert system to ensure all veterans receive academic, career, and financial advice before challenges become overwhelming.

4. Coordinate and centralize campus efforts for all veterans, together with the creation of a designated space (even if limited in size).

5. Collaborate with local communities and organizations, including government agencies, to align and coordinate various services for veterans.

6. Utilize a uniform set of data tools to collect and track information on veterans, including demographics, retention and degree completion.

7. Provide comprehensive professional development for faculty and staff on issues and challenges unique to veterans.

8. Develop systems that ensure sustainability of effective practices for veterans.

Two hundred and fifty schools responded they would commit to the guidelines introduced in the 8 Keys of Success, which indicated some institutions were open to the recommendations and were ready to make the required modifications on their campuses. The U.S. Department of Veterans Affairs, the Servicemembers Opportunity Colleges (SOC) Consortium, the national Student Veterans of America Association, and the Council on Education have posted very similar guides on their websites prior to the introduction of the 8 Keys. 


\section{Value of the Military Friendly Brand}

Being designated as military friendly or veteran friendly are highly sought after brands used by many non-profit and for-profit institutions in higher education. As both names can be used interchangeably to describe a school's student support focus, the researcher's preference was military friendly. A definitive description has not been determined so the term's meaning remains ambiguous as each school emphasized the necessary services and attention afforded to their military community (Howell, 2012).

Visible promotion of the brand were often affixed on veterans' websites at many colleges and universities. It was symbolic of schools that advocated military friendly policies, practices, and support. These institutions purposely aligned with websites such as Military Times (http://www.projects.militarytimes.com/jobs/best-for-vets/2013/colleges/4-year/), G.I. Jobs (http://www.militaryfriendlyschools.com/), and Military Advanced Education (http://www.kmimediagroup.com/military-advanced-education/2013-guide-to-militaryfriendly-colleges-a-universities.html) and others.

In some instances, ranking of U. S. colleges and universities included categories such as the Military Times' Best for Vets classifications by 4-year colleges, 2-year colleges, Career and Technical colleges, online, and nontraditional colleges. Accountability was nonexistent because these websites lacked adequate evaluation of college students' progress and success. More reliable information sources such as the VA (2013) and the American Council on Education (2013) have upgraded their college search websites on a continual basis assisting U.S. troops and veterans to make informed decisions on their school selection.

For the most part, the value attached to lists or guides is that they are useful resources that created awareness, stimulated interest, provided quick information at no financial cost, and 
were easy to peruse at will. They offered a practical option for student service members and student veteran consumers of higher education services. Most often, the list of schools were displayed on websites deemed popular and frequented by military members, veterans, and dependents around the world.

\section{Military Friendly Expectations}

The downsizing by some branches of the Armed Services, drawdown of troops from war zones in the Middle East, and the impending separation of service members from the military accelerated their return to civilian communities in large numbers. It was expected that many honorably discharged warriors had wisely invested their GI Bill funds in a school or training program that expedited this process and exemplified the essence of military friendliness in culture and practice.

Those being advertised as military friendly may have been perceived as the ideal choice based simply on the designation alone. In turn, student service members and student veterans likely held the expectation that the campus was a good fit because it closely aligned with their personal criteria such as location, cost, housing, major, etc., and one in which they found compatibility with other students having military background. They formed a cohesive peer group on campus described as "collegiate veterans made up of like-minded people with similar history...who are in the same situation" by United States Marine Corps (Ret.), Colonel Michael Denning, Director of the Kansas University Office of Professional Military Graduate Education (Altus, 2012, p.7).

The campus climate was purported to have implemented comprehensive and integrated resources with these students in mind. It was one in which key administrators had readily adapted their institutions' best practices to promote transition support and provided 
administrators, staff, and faculty with training that developed their knowledge, proficiency, sensitivity, and awareness of the reintegration concerns of this student group (American Council on Education, 2013).

\section{Momentum of Institutional Change and Support}

Since 2001, a growing number of higher education institutions displayed visible action toward ensuring their military and veteran student population experienced seamless transitions. Schools publicized this information in their recruitment efforts and advertisement to military personnel. Specific resources have increased on campus such as: separate newstudent orientation sessions, mentoring programs, lounges, housing, and one-stop Military/ Veteran Affairs centers. New courses were introduced to help ease students' adjustment and some schools allowed in-state tuition for their military and veteran population.

Some colleges and universities awarded college credit for classes taken during military service, which has drawn the support of the American Council on Education (ACE). They had recommended to more than 2,300 colleges and universities that official documentation of military transcripts be given consideration (American Council on Education, 2013). A growing number of schools extended financial assistance through the Yellow Ribbon Program to cover tuition and fees known as "gap costs," for those students whose GI Bill benefits had been depleted and still needed to complete their program of study and graduate (U.S. Department of Veterans Affairs, 2013). A list of Yellow Ribbon schools across the country were posted annually on the VA website.

\section{Student Veteran Lounge}

The physical location of 'place' on campus was an essential type of organization support that emphasized the value and visibility institutions placed upon their military and 
veteran student population. Not all colleges and universities had a student veteran lounge. It was a gathering 'space' separated from civilian student peers where student veterans could congregate as a group or privately at their own leisure. They were provided with the opportunity to "always tap into the network of former or active members of the military likely to exist at any university to seek guidance," support and information (Altus, 2012, p. 7).

This was an important resource that many schools that showcased their military friendliness had failed to prioritize. It had become a vital issue of students' retention and persistence that the President of the United States made it one of the requirements in the 8 Keys of Success, "Coordinate and centralize campus efforts for all veterans, together with the creation of a designated space (even if limited in size)" (Baker, 2013, para 5). The American Council on Education, Student Veterans of America, and Servicemembers Opportunity Colleges have recommended the same physical evidence of support to higher education for years.

\section{Social Justice}

The military friendliness of any campus or lack thereof was subjective based on the individual student's perceptions. Any incidences of hostility, disrespect, and insensitivity being directed at student service members and student veterans by other student groups, faculty, staff or administrators were often not visibly evident on an individual basis and even overlooked in the context of the learning experience. It was through the nature of research over the years about military and veteran students' engagement in college work as a group that disclosed details of some non-academic realities they confronted otherwise.

Studies on this subpopulation showed patterns of social justice issues these students reported frequently to researchers such as: (1) being asked if they killed someone in the war 
or knew of someone that died in the war (DiRamio et al., 2008, p. 88; Livingston, 2009, p. 116; Normandin, 2010, p. 83); (2) the insinuation or declaration that they ate babies, were baby killers and torturers (Doenges, 2011, p.62; Elliott, Gonzalez, \& Larsen, 2011, p. 287); (3) those professors that discussed negative aspects of the war in class and were visibly oblivious to the discomfort of their students with military experience (Ackerman et al., 2009; Elliott, Gonzalez \& Larsen, 2011); (4) students and faculty members that downgraded the war and the role of military personnel directly to the military or student veteran (Ackerman et al., 2009; Naphan, 2011, Wheeler, 2011); (5) faculty that identified military students to others in the classroom during lectures or discussion of the war (Naphan, 2011, pp.70-74); and (6) professors that called on service members and veterans to share their opinions about the war and suggested that individual spoke on behalf of all military students on campus (Naphan, 2011, pp. 70-74; Wheeler, 2011, pp. 118-123).

These instances should be regarded similar in nature to asking Black students about slavery, Hispanic students about illegal immigrants, or Muslim students about terrorists. These disturbing snippets of collegiate experience were undoubtedly social justice matters that required the protection of all military and veteran students in the institution's policies, the classroom, and within higher education climates that professed to be military friendly.

\section{Significance of Camaraderie}

In their zeal to recruit from the military community, it was expected that the cultivation of camaraderie among student service members and student veterans took precedence at military friendly colleges and universities. Camaraderie is an informal support system identified within the higher education climate that extends beyond the formal institutional support systems of Academic and Student Affairs. Although it was a term often associated 
with the relationship of trust and support among individuals in various peer groups, the researcher differentiated it further as a unique bond that exemplified selfless support like no other, rooted in military members' service in the U.S. Armed Forces.

It was reflective to a lesser degree of the mutual trust, honor, respect and rapport first established in the military culture, in wartime, when individuals were at-risk, or when one's life was at stake and dependent on another in hazardous circumstances. The repercussion of war was aptly described in an aphorism penned by Argentine author Jose Narosky, "In war, there are no unwounded soldiers" (as cited in Goldbloom, 2011).

The United States had been at war for over a decade. Transition became increasingly meaningful when it was linear in nature such as those experienced by the influx of contemporary student service members and veterans who were involved in the Global War of Terror and enrolled in college (Figure 1).
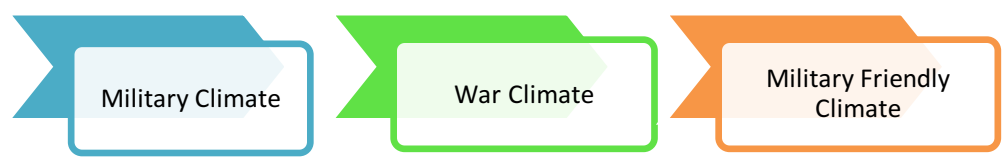

Figure 1. Military Members' and Veterans' Transition Route to Higher Education

They shared first-hand knowledge and comprehension of similar experiences men and women encountered in the presence of war, or peace-time service in the Armed Forces; which has been found to forge a unifying and supportive alliance (Money, 2011). The military members who were involved in the Global War of Terror and enrolled in college shared common ground on personal, academic, and social issues during transition (Bissell, 2013; Wounded Warriors, 2012).

Although inexplicable, camaraderie was acknowledged even when military commitment was completed. This was a bond that some students needed to help circumvent 
the daily stressors related to evolving in the campus culture. Military and veteran peers' camaraderie may be effective in weeding out role models and mentors that provided the emotional and social support not found anywhere else on campus. Chickering and Reisser (1993) offered their perspective on students' holistic engagement in college, "to learn, students' basic needs such as nutrition, physical well-being, social support, and a sense of community, must be met" (Evans, Forney, \& Guido-DiBrito, 1998).

Summary

This chapter presented the literary basis for the exploratory research of the military friendly phenomena promoted by many colleges and universities. Past studies highlighted the personal and academic issues that framed contemporary student service members' and student veterans' positive and negative college transitions. Some of the collegiate barriers they reported upon first involvement in the campus culture were: administrative processes, academic rigor, student life routines and interactions with civilian peers and faulty. For the most part, this subpopulation's access and involvement in academe was funded by the GI Bill. A comprehensive description of the mixed methods design used to collect and analyze narrative and numerical information was next presented in Chapter Three. 


\section{CHAPTER THREE}

\section{METHOD}

The exploratory aspect of research was determined to be the most informative course to pursue understanding of the military friendly phenomena at seven public colleges and universities in the United States. This was the underlying foundation relevant to students' experiences unaccounted for in studies involving student service members' and student veterans' participation and performance during transition in higher education. The researcher ascribed to a perspective offered by Terrell (2011) that insight, depth, and breath of the results were enhanced when a problem was studied with more than one research method (p. 258). Keeping this in mind, a mixed methods course of action was selected to acquire data.

The narrative format of qualitative data presented the perceptions service members and student veterans attached to their meaningful experiences in military friendly climates and the significance of their relationship with one another manifested in camaraderie. The numerical information of quantitative data placed value on the frequency of their experiences and perceptions. As no one military member or veteran could have spoken for all, the quantitative aspect drew upon this student groups' consensus about transitioning in college (Clark \& Creswell, 2008; Green \& Caracelli, 1997).

The purpose of this study was to explore the degree to which colleges and universities claiming to be military friendly campus climates, supported student service members' and student veterans' transitions through their policies, practices, and resources. Also of interest was the exploration of the phenomenon of camaraderie found among student service members and student veterans that evoked feelings of success in higher education within the military friendly parameter. 
The four research questions explored were:

RQ1-A: What are student service members' and student veterans' perceptions of their military friendly campus climates?

RQ1-B: What are student service members' and student veterans' academic success and transition from the Armed Forces to higher education in relation to their perceptions of military friendly campus climates?

RQ2-A: What are student service members' and student veterans' perceptions of camaraderie among military peers at military friendly campuses?

RQ2-B: What are student service members' and student veterans' academic success and transition from the Armed Forces to higher education in relation to their perceptions of camaraderie among military peers?

\section{General Recruitment of Participants}

The researcher contacted twenty colleges and universities throughout the United States by email or phone call. In addition to universities in West Virginia that identified themselves as military friendly schools, two other sources were used - the national Student Veterans chapter website (http://www.studentveterans.org) and the Guide To Military-Friendly Colleges and Universities posted in the Military Advanced Education Journal (http://www.kmimediagroup.com/mae).

Access to student service members and student veterans was through the organizational hierarchy at each institution. The researcher began with the Office of Military/Veterans Affairs located at the various campuses. The West Virginia University Institutional Review Board (IRB) approval letter and the research information were sent to key administrators by email to gauge their interest and support. Seven schools elected to take part in the exploratory research. 
Concord University in Athens, West Virginia, served as the site of the focus group in Phase I. In Phase II, administrators were sent a second email that included a copy of the survey for their review, the student recruitment email and the survey link posted on Qualtrics to be forwarded to students.

Participant outreach was determined through various communication channels such as: the campus military student listserv, Office of Military/Veterans Affairs announcement board, Facebook, Student Veterans chapters and word of mouth. This process of recruitment allowed for random sampling and controlled for selection bias and error (Patton, 2002, p. 230).

Full time and part time undergraduate and graduate students who had served on activeduty or were still serving in the United States Armed Forces, including Reserves and National Guard members were recruited to take part in both phases. This criterion excluded military dependents and ROTC cadets attending college. Participants' diversity of age, race and gender were important aspects of the exploratory nature of the research.

\section{Research Design}

A sequential exploratory design was used to collect qualitative and quantitative data in two phases (Clark \& Cresswell, 2008, pp.180-182 ). Priority was given to the qualitative data collection conducted in Phase I in which a focus group was used. This setting afforded student veterans with the opportunity to congregate in one location at the same time and share their perceptions of college transition with each other. The camaraderie observed among group members was the primary reason the researcher chose this form of interview method.

Typically comprised of six to ten people with similar experiences or backgrounds, focus groups offered individuals a platform to voice their opinions (Kvale \& Brinkmann, 
2009, p.150; Patton, 2002, p. 385). In general, many people were comfortable meeting together socially (Krueger, 1994, p. 8; Patton, 2002, p. 386) and have the opportunity to spontaneously discuss their perceptions of events and life experiences (Patton, 2002). Compared to conducting personal interviews, focus group meetings had a permissive atmosphere which was ideally suited for the researcher's convenience to collect a lot of information in a short span of time. An important aim in using this form of qualitative data collection was that it did not require people to solve problems or be in agreement at all times (Kvale \& Brinkmann, 2009, p. 150; Patton, 2002, p. 385). Respondents' narratives provided qualitative data from an "inductive-subjective" point of view (Clark \& Cresswell, 2008, p. $61)$.

Advantages. Exploratory research in a "new domain" benefitted from information discussed by group members (Kvale \& Brinkmann, 2009, p. 150). The data produced believable results at a reasonable cost. Individuals' viewpoints were quickly assessed. The researcher's observation of group members' interactions enhanced the quality and interpretation of the data (Terrell, 2011). Focus groups had flexibility and "high face validity" (Babbie, 2004, p.303). New ideas for future research stemmed from the large quantity of data, indicative of trends, themes and patterns.

Disadvantages. Questions were greatly restricted to the time allotted for discussion and by the number of people in the sample. Some participants' responses had to be curtailed in order to give equal opportunity to other people to answer questions. Confidentially was not assured. In order to avoid "atypical results" that were not statistically representative of the population focused upon, some researchers needed to conduct more than a one focus group (Babbie, 2004, p. 303). 
The data was not beneficial for micro-analysis of subtle differences. Most focus groups were not held in the natural surroundings where participants normally had their daily routines (Patton, 2002, pp. 386-388; Terrell, 2011). However, the focus group in this research was conducted in the Veterans Lounge which was frequented by students.

Focus group information was significant as it informed the development of the questionnaire Where Failure Is Not The Option Military Friendly College/University Survey (WFINTO SURVEY) (Appendix A) administered in Phase II.

Surveys. Quantitative data collected in the web-based survey in Phase II provided descriptive information and the statistical value of service members' and student veterans' perceptions of their enrollment at military friendly schools. Clark and Cresswell (2008) indicated surveys generated data that were "deductive-objective-and generalizing" (p. 61). These were important characteristics that created possibilities for further exploration and increased the value of the phenomena being examined (Brazely, 2004).

Researchers used larger samples because surveys in general were cost effective. As a standardized measuring instrument, all respondents were asked the same, exact questions. In this way, the validity and reliability of the measurement was increased (Salkind, pp. 101-102, 112). In addition to paper copies, surveys delivered online allowed respondents' more privacy as they were able to use computers at any location and time of day.

Self-reported information was one of the disadvantages associated with using surveys because individuals' truthfulness and integrity were not predetermined. Assistance and question clarification were not readily available to respondents. This situation increased misunderstanding, wrong information, questions not being answered or participants dropping out of the research. 
Instrument. The WFINTO SURVEY developed by the researcher was comprised of information collected in Phase I and guided by past studies on student service members and student veterans in higher education (Hadley, Trechter, \& Parks, 2011; Kim \& Cole, 2013; Lang \& Powers, 2011; McBain, Kim, Cook, \& Snead, 2012; Sternberg, Wadsworth, Vaughn, \& Carlson, 2009; UWRF Veterans Survey Report, 2011; Weiss, 1973, 1974;

Zinger \& Cohen, 2010). The sections included demographic information and was aligned with the four research questions.

Questions related to camaraderie were influenced by the six components of the Social Provisions Scale developed by Weiss $(1973,1974)$ and the modified version that Cutrona and Russell $(1987,1990)$ presented (Table 2).

Table 2

Combined Six Components of the Social Provisions Scale

Weiss Cutrona and Russell

1) Guidance

2) Reliable Alliance

3) Reassurance of Worth

4) Attachment

5) Social Integration

(advice or information) (assurance that others can be counted on in times of stress) (recognition of one's competence) (emotional closeness) (a sense of belonging to a group of friends)

o) Opportunity for Nurturance (providing assistance to others)

Note: Adapted for Camaraderie section on WFINTO survey (Cutrona \& Russell, 1987, 1990; Weiss, 1973, 1974)

The combined provisions were determined by the researcher to be the best overview of personal and social support that highlighted important factors related to the bond of camaraderie found among student service members and student veteran peers in a descriptive non-experimental study.

This complied with Weiss' original social provision that relationships are 
reciprocal in nature which Cutrona and Russell $(1987,1990)$ updated, and the researcher found applicable to contemporary college students. The attributes reported to be inherent in the bond witnessed among service members in general were also emphasized.

The survey consisted of forty-four closed-ended and four open-ended questions total within the following categories: (1) Military Friendly School, (2) Transition, (3) Camaraderie, and (4) Demographic Information. Four open-ended questions served to elicit qualitative data: \#8 How would you describe a military friendly University/college that meets your personal expectations?

\#11 Please describe why you may fail to complete your education at this university/college and not graduate with your degree.

\#18 How would you describe to a civilian what camaraderie is as it relates to military members and veterans on campus?

\#44 Is there anything else you would like to share about your experiences at a Military Friendly University/College?

Implementing qualitative questions were generally characteristic of exploratory research. The types of closed-ended questions used in the survey were: Categorical, Multiple-choice, Likert-scale, and Numerical. Scoring on the Likert-scale ranged from 1-Strongly Disagree, 2Disagree, 3- Neither Agree nor Disagree, 4- Agree, 5- Strongly Agree.

Five student veteran alumni pre-tested the WFINTO SURVEY for sensitivity of language, type of research questions posed, relevance to the research questions, number of questions, and survey completion time. Based on their feedback the original draft was revised. A second evaluation of the instrument was conducted by two other veterans. They found the modified version of the survey to be sufficient for exploratory research purposes. Participant 
fatigue was an important consideration. The survey time was found to be 12-25 minutes which was dependent upon the respondent's attention allotted to each question. Those answering any or all of the open-ended questions extended their survey completion time.

Triangulation. The data was triangulated in order to increase the validity of the study. The strengths of qualitative and quantitative information served to counter-balance the other (Clark \& Cresswell, 2008, p.108). In this way, qualitative descriptions had a complementary purpose and supplemented quantifiable information. Importantly, this process allowed for the "clarification and interpretability of different facets of the phenomena" as the military friendly

college and university (Clark \& Cresswell, 2008, p. 126). The mixed methods approach elaborated the holistic quality of individuals' realities and their perceptions, and preservation of their words in the data that provided meaningful conclusions.

\section{Samples, Settings, Procedures, and Analysis}

Phase I-Focus Group. Four public universities in West Virginia were contacted by the researcher to recruit focus group participants: Concord University, Marshall University, West Virginia State University, and West Virginia University.

Timely and substantive support was received from the Veterans Coordinator/Certifying Official and a Navy veteran and work-study student in the Concord University Veterans Office. They quickly informed the military and student veteran population about the research. Recruitment resulted in seven focus group participants. Among group members were six undergraduates and one graduate student, representative of service in the Air Force, Army, Navy, and the Marine Corps.

The purposeful sample of six males and one female was due to their availability at a specific date and time during the spring semester. They were identified by pseudonyms in 
the focus group data. Patton (2002) suggested that "the logic and power of purposeful sampling lie in selecting information-rich cases for study in depth" (p. 230) which aligned with the exploratory nature of the research. As a heterogeneous group of people, their diversity was important to the enrichment of the data pertaining to gender, age, military affiliation and rank, time in service, college status, major, career goals, and marital status. The data represented the perceptions of Caucasian student veterans as they were the only individuals who had agreed to take part in Phase I.

Concord University was located in southern West Virginia, in the small, rural town of Athens. Founded in 1872, the "Campus Beautiful" had a serene environment in which to pursue Liberal Arts studies. In 2013, undergraduates totaled 2,510 with 285 graduate students. Ranked as the \#1 veteran friendly school in the United States in 2011-2012, the institution made headlines again with the 2014 Military Time Edge Magazine ranking of \#3 in Best 4-Year Colleges for Veterans (http://www.concord.edu/about-concord).

The collaborative leadership of the past Concord University President, Veterans Coordinator and other administrators had set into motion support measures for students with military background. Visible support included: a Veterans Lounge, tutoring, mentoring, crisis intervention teams/modules, and faculty training. New veteran courses were planned for future student cohorts.

Veterans and dependents of service members frequented the Veterans Lounge during the school year and given their own keys to gain access at will. It was a very large and spacious room equipped with lots of comfortable seating (overstuffed couches/loveseat/big, roomy chairs), TV, refrigerator, table/chairs, computers, dry-eraser board and shelves lined with books. There was space for students' privacy and to congregate as a group. 
Sunlight streamed in through the windows in addition to the artificial lighting in the room on the day of the focus group meeting. The atmosphere was a balance of cheerful, cozy, pleasant and relaxing. It was a setting that was further enhanced by the décor and artwork hung on the walls. The room was a blend of military/valor/masculine/feminine/neutral and academic aesthetics, dependent on an individual's' outlook and interpretation, including the researcher's. The Veterans Lounge on campus could have been tagged a safe haven, sanctuary, refuge, gathering place, one-stop center, study room, or a 'home away from home' by some. The designation itself was not as important as how it was applicable to a student's perception of the room's purpose, befitting their need, issue or concern at any given time.

Pizza and soda was provided by the researcher during the informal gathering with veterans and dependents prior to the start of the focus group session. The researcher also moderated the discussion that followed. Participants were instructed to read and sign the Informed Consent form and answer the short number of questions listed on Demographic Information, prior to the start of the 90 minute tape-recorded session. After introductions were made by each veteran, the moderator then referenced the Focus Group Question Guide which consisted of leading and follow-up open-ended questions (Table 3). 
Table 3

Research Questions and Corresponding Focus Group Questions

\begin{tabular}{l} 
Research Questions \\
\hline RQ1-A: \\
What are student service members' and student \\
veterans' perceptions of their military friendly \\
campus climates?
\end{tabular}

RQ1-B:

What are student service members' and student veterans' academic success and transition from the Armed Forces to higher education in relation to their perceptions of military friendly campus climates?

\section{RQ2-A:}

What are student service members' and student veterans' perceptions of camaraderie among military peers at military friendly campuses?

\section{RQ2-B:}

What are student service members' and student veterans' academic success and transition from the Armed Forces to higher education in relation to their perceptions of camaraderie among military peers?

\section{Focus Group Questions}

(1) What are your thoughts about a college or university that identifies itself as being a military friendly school?

(1a) How important is the military friendly brand to you as as a student?

(6) What would you like to see your school do for military and student veterans on campus?

(2 ) Please tell me about your transition from the military to college.

(2 a) Is there one positive college experience you'd like to tell us about?

(2 b) Is there one negative or challenging college experience you'd like to talk about?

(2 c) In what way does a military friendly school help you to graduate?

(3) If you had to explain camaraderie to a civilian what would you say?

(5) What could be a reason that some military members or veterans don't associate with their military peers or say they don't know of other students on campus with military experience?

(4) How important is camaraderie to staying in college, graduating and attaining your degree? 
The Guide was reviewed beforehand by five student veteran alumni. Materials used in Phase I included: two digital tape recorders, pens, two notebooks and seven copies each of the Informed Consent and Demographic Information forms. At the end of the discussion, participants were thanked and given an envelope that contained the researcher's business card and $\$ 20$ gratuity.

Qualitative Data Analysis. The phenomenology approach was used to draw out hidden meaning of the nature of service members' and student veterans' realities influencing transition and college life (Grbich, 2007, p. 84; Kvale \& Brinkmann, 2009, p. 26). Thirty-one pages of raw data was transcribed verbatim twice, as two tape recorders were used during the focus group discussion. Having a backup recording served to forestall mechanical issues and human error. Check coding was used to determine reliability of the documents in which both transcribed scripts were compared and reviewed numerous times, providing verification and accuracy of participants' words (Kvale, 1996).

This information was referenced with observational field notes and the researcher's preliminary assessment notes written during the focus group meeting. Lincoln and Guba (1985) held the perspective that it was necessary to the credibility of the study to use member checking of the data initially collected. The researcher was not inclined to use this procedure. The element of discovery would be compromised by the possibility of having a cycle of re-assessment by the participants of what has already been said, recorded and transcribed; which would include any information they may have wanted to add or delete.

The researcher was also of the opinion this process would have manipulated the 
information and the integrity and power of participants' extemporaneous words, reflecting a scripted dialogue to a degree. Member checking was not used in order to preserve the spontaneity and quality of the data as the research was of an exploratory nature. Importantly, the development of the survey was a priority in order to achieve the timely completion of the research. Follow up with the participants would have stalled progress. Therefore, member checking was not appropriate in this instance.

Three occasions for observation of camaraderie (non-verbal and verbal behaviors) had taken place among students in the Veterans Lounge: prior to the start of the focus group meeting, during, and after the discussion. The extent of reactivity, group members' interaction and engagement with one another did not indicate the likelihood that their behaviors had changed extensively during the short research timeframe from their customary responses (Paterson, 1994).

The value of observation was to gauge veterans' tacit knowledge among military peers which Altheide and Johnson (1994) described as the "largely unarticulated, contextual understanding that is often manifested in nods, silences, humor, and naughty nuances" (pp. 492-493). These mannerisms were noticed by the researcher and helped to substantiate the rapport of group members. Due to research time constraints, additional observation opportunities were not presented or planned, this would have increased the reliability of observation as recommended by Denzin and Lincoln (1998).

I sensed that my role as a researcher was eased and found to be acceptable to a degree because I was a military dependent and in a position to engage with a community that was familiar to me. For a brief two hours I was once again a member of the larger and extended military family and my participants could relax, be themselves, talk to me, tell 
jokes and make humorous remarks and still share their true feelings and thoughts. I appreciated their candor and welcomed the chance to smile and laugh on occasion. Therefore, I allowed them full control of the amount of information they shared and wanted me to know guided by the questions I asked. I felt that I was in an atmosphere of mutual trust and respect, reinforced by our bond.

Information that were not relevant to the research questions were placed in a separate file without detracting from participants' unique stories (Riessman, 2002). The significant words, tone, and quality of the individual's narrative was kept intact, deemed truthful by the researcher and advantageous to the research purpose.

The realism of transition for the student veteran population was acknowledged in verisimilitude. It fostered trustworthiness in the quality, impression, and existence of the truths individuals disclosed. Its value lies in the transference of understanding to others, although distinct in nature, it appeals and corresponds to the instinctual and holistic outlook of the reader; while providing a simplistic explanation of the inherent complexities of the world and the diversity of people. According to Eisner (1997) verisimilitude holds the possibility that "others have access not only to our lives when our stories are about them but also to the lives of others" (p. 264).

Initial open coding involved reducing and sorting the data into categories and subcategories, drawing out themes that relied on "aspects of accounts that are being told" (Riessman, 2008, p. 3). General patterns were detected that included repetitive words, phrases and details that contrasted or were similar in context. Similarities were strands that filtered out words, these "binary oppositions" (e.g. smiling face, frowning face) enriched the data and decreased generalizing the information (Rosenwasser \& Stephen, 2006, p. 
89).

The researcher used a process described by Kvale and Brinkmann (2009) as “phenomenological reduction that suspended judgment" of participants' experiences in order to present an "unprejudiced description of the essence of the phenomena" (p. 27) in interpretation. Emerging themes were determined that provided insight of the predominant circumstances that impacted students' adjustment and learning at a military friendly school (Grbich, 2007, p. 89). The three themes identified were: (1) A military friendly climate is one that is presently beneficial for students and develops strategies of support in anticipation of their needs; (2) The quality of transition in a military friendly climate fosters students' success and persistence, prevailing over challenges; and (3) Camaraderie is an adaption of the individual veteran's desired support and degree of reciprocal social interaction within the military community on campus.

\section{Phase Two-Web Survey}

Each institution's Office of Military/Veterans Affairs administrator that supported the research forwarded the survey link to students. These key personnel in higher education had a pivotal influence on the continuity of the research and number of respondents that completed the survey. The value of this important relationship between administrator and researcher had become the defining determinant in having successful data collection in Phases I and II. This unanticipated turn of events became the first limitation the researcher encountered in finding a minimal number of administrators who would readily say 'yes to the research' out of the twenty schools contacted.

Qualtrics software was used to collect quantitative data. The expanding technology of internet delivery of questionnaires had become acceptable in current times (Hewson, 2003). 
Participants accessed the web-based survey from May through June 2014. This was an appropriate duration of time for most college students who were completing spring semester classes and those beginning summer courses.

The 14\% dropout rate from 198 respondents at the start of the survey resulted in 170 that completed surveys. Students were given the option to contact the researcher directly regarding questions and concerns, this information was posted on the Informed Consent section. Participants did not have to answer questions they found not personally applicable or felt uncomfortable with. This was one of the considerations the researcher outlined in receiving research approval from the West Virginia University IRB.

The sample was recruited from seven higher education institutions designated as being military friendly. Respondents represented all five branches of the U.S. Armed Forces: Air Force, Army, Coast Guard, Marine Corps, and Navy (Table 4).

Table 4

State Locations of Military Friendly Universities and Colleges

\begin{tabular}{lcc}
\hline State & Frequency & \% \\
\hline Arizona & & \\
West Virginia & 99 & 59 \\
Hawaii & 34 & 20 \\
California & 20 & 12 \\
Pennsylvania & 9 & 5 \\
Minnesota & 4 & 2 \\
Virginia & 2 & 1 \\
& 1 & 1 \\
\hline
\end{tabular}

The question response rates varied on the survey, particularly questions with qualitative components in which participants typed in their answers. This was characteristic of exploratory purpose which illuminated participants' perspectives in the 
phenomenological approach used. All the recorded data was valuable to the researcher whether the survey was completed in its entirety or not, as the data perpetuated the human story. At the end of the survey, respondents were given the opportunity to enter a drawing for one of ten $\$ 25$ gift cards which was accessed by a separate link.

Quantitative Data Analyses. Qualtrics software was used to analyze descriptive statistics for the following variables that correspond with the four research questions and those listed on the WFINTO survey (Table 5):

* Students' perceptions of campus climate

* Students' perceptions of camaraderie

* Student Success (GPA, graduation date, course completion, number of credit hours, attendance, time management, attending orientation, academic and professional development, student group membership, service learning, study abroad, school leadership, application for scholarships and fellowships, Dean's list, internship, Honors Program, McNair Scholars Program)

* Transition (friends, extra-curricular activities, support services, asking for assistance, civilian peers and faculty, veterans courses, GI Bill benefits, enrollment in college) 
Table 5

Survey Questions that Correspond with the Four Research Questions

RQ1-A: What are student service members' and student veterans' perceptions of their military friendly campus climates?

$1,2,7,8,43$

RQ1-B: What are student service members' and student veterans' academic success and transition from the Armed Forces to higher education in relation to their perceptions of military friendly campus climates?

Success: $9,10,11,12,13,20,24,25,32,33,34,36,37,39,41$

Transition: 3, 4, 5, 6, 22, 23, 28, 29

RQ2-A: What are student service members' and student veterans' perceptions of camaraderie among military peers at military friendly campuses?

$14,15,16,17,18,26,27$

RQ2-B: What are student service members' and student veterans' academic success and transition from the Armed Forces to higher education in relation to their perceptions of camaraderie among military peers?

Success: $9,10,11,12,13,20,24,25,32,33,34,36,37,39,41$

Transition: 3, 4, 5, 6, 22, 23, 28, 29 Camaraderie: 14, 15, 16, 17, 18, 26, 27

Questions were measured with a Likert scale of 1-5 that showed frequency of responses and percentages. Central tendency and frequency were assessed for quantitative data derived from closed-ended questions (Salkind, 2008, p. 8). The qualitative information acquired from the open-ended questions were sorted into categories, coded for patterns and general themes, and evaluated for word frequency and phrases. Plausible definitions for military friendly and camaraderie were determined.

Due to the nature of exploratory research, the amount of qualitative data collected 
from using a mixed method design exceeded the needs and purpose of the research. As the four research questions were sufficiently addressed, other information from the survey and focus group were stored for in-depth analysis in a future report.

\section{Issues of Trust and Anonymity}

The researcher was aware that in recent years the Office of Military/Veterans Affairs at various campuses across the country have frequently been contacted by researchers and the media. Therefore, it was not surprising to have an administrator inform her that their military students were inundated with attention and wasn't certain they would be open to another research at that particular time. For this reason, the researcher conveyed to key administrators and participants in the student recruitment email that she was a military dependent interested in completing a dissertation about a community of students she was familiar with. This information minimized barriers to the continuity of the research.

Participants had the option to drop out of the study at any time, not answer questions they felt uncomfortable with, and were informed they could use a pseudonym in the focus group. Respondents who completed the web-survey were not asked for their names. Those entered in the gift card drawing were asked for their contact information (name and email) for notification in the event they won.

Students' names were requested of those who entered the gift card drawing only when they accessed a separate link to submit contact information. Although not required, some participants listed their first and last names. Focus group participants were asked for their names on the Demographics Information form should the researcher needed clarification of their responses. The confidentiality of all information received was duly noted by the researcher and not shared with other parties. Ethical standards were maintained in conducting research in 
which participants' anonymity was important and a trustful relationship was anticipated.

\section{Summary}

A sequential exploratory mixed methods design was used in which qualitative and quantitative data advanced the purpose of the research on service members' and student veterans' transitions at military friendly colleges and universities. Qualitative data collected in a focus group informed the researcher-developed questionnaire administered to respondents. Qualtrics software delivered the web-based WFINTO SURVEY and analyzed the data for descriptive statistics and frequency.

The next chapter summarized the pertinent information found in Phase I and II that aligned with the four research questions. 


\section{CHAPTER FOUR}

\section{RESULTS}

This report highlighted the collective opinions of students having past or present military experience. They were the best source to judge as to how they perceived their performance in their programs of study, and assess the college or university they selected to complete a degree. The focus group was the foundation of the research in which participants shared their thoughts about transition in a military friendly school that was markedly supportive of the military student community. Supplementary information was also provided by a greater number of respondents who had completed an online survey, that furthered insight of the military friendly phenomenon and the diversity of students' collegiate experiences in this climate.

The researcher contacted twenty colleges and universities throughout the United States by email or phone call. In addition to universities in West Virginia that identified themselves as military friendly schools two other sources were used - the national Student Veterans chapter website (http://www.studentveterans.org) and the Guide To Military-Friendly Colleges and Universities posted in the Military Advanced Education Journal (http://www.kmimediagroup.com/mae).

Access to student service members and student veterans was through the organizational hierarchy at each institution. The researcher began with the Office of Military/Veterans Affairs located at the various campuses. The West Virginia University Institutional Review Board (IRB) approval letter and the research information was sent to key administrators by email to gauge their interest and support. Seven schools elected to take part in the exploratory research. Concord University in Athens, West Virginia, served as the site of the focus group in Phase I. In Phase II, administrators were sent a second email that included a copy of the survey for their 
review, the student recruitment email and the survey link posted on Qualtrics to be forwarded to students.

Participant outreach was determined through various communication channels such as: the campus military student listserv, Office of Military / Veterans Affairs announcement board, Facebook, Student Veterans chapters and word of mouth. This process of recruitment allowed for random sampling and controlled for selection bias and error (Patton, 2002, p. 230).

Full time and part time undergraduate and graduate students who had served on activeduty or were still serving in the United States Armed Forces, including Reserves and National Guard members were recruited to take part in both phases. This criterion excluded military dependents and ROTC cadets attending college. Participants' diversity of age, race and gender were important aspects of the exploratory nature of the research.

The results were not reflective of the larger population of student service members and student veterans enrolled in college during May-July, 2014 in the U.S. One hundred-seventy respondents $(n=170)$ from seven military friendly colleges and universities completed the webbased WFINTO SURVEY. The sample was random as students took part in the research of their own volition by accessing the survey link forwarded by the Office of Military/Veterans Affairs administrator at each institution. The sample was not pre-determined as the seven focus group members $(n=7)$ at Concord University in West Virginia, who were purposely selected due to their availability on a specific date and time.

The information presented in this chapter reflected the purpose of the study, to explore the degree to which colleges and universities claiming to be military friendly campus climates supported student service members' and student veterans' transitions through their policies, practices, and resources. Also of interest, was the exploration of the 
phenomenon of camaraderie found among student service members and student veterans

that evoked feelings of success in higher education within the military friendly parameter.

Four research questions were addressed:

RQ1-A: What are student service members' and student veterans' perceptions of their military friendly campus climates?

RQ1-B: What are student service members' and student veterans' academic success and transition from the Armed Forces to higher education in relation to their perceptions of military friendly campus climates?

RQ2-A: What are student service members' and student veterans' perceptions of camaraderie among military peers at military friendly campuses?

RQ2-B: What are student service members' and student veterans' academic success and transition from the Armed Forces to higher education in relation to their perceptions of camaraderie among military peers?

\section{Focus Group}

The focus group held on the afternoon of May 1, 2014, in the Veterans Lounge at Concord University (CU) in Athens, West Virginia involved seven student veterans. Pseudonyms were assigned to the six males and one female. Participants completed the Demographic Information form in which they recollected their college trajectory, use of military education benefits, and perception of academic progress. A synopsis of each group member's description provided background information that exemplified the diversity of college students with military experience.

CAM 1, age 62, served in the Navy and enrolled at CU as a freshman. He was a full time student in the Social Work master's program, happy with his academic progress, and expected to 
graduate in spring semester, 2014. CAM 1 received VA education benefits and planned to pursue a career with the U.S. Department of Veterans Affairs (VA) as a PTSD Advocate. He was married with children. As a Work-Study Assistant in the Veterans office on campus, he worked closely with the Veterans Coordinator/Veterans Certifying Official/Advisor, and the student veteran population including dependents (spouse or children of service members attending CU).

His length of time since separation from the military to college enrollment was seven years. CAM 1 was often found in the Veterans Lounge providing assistance, information, guidance, and humor. His role as a liaison was proactive and vital to the well-being, persistence and retention of students. He has been one of the leading advocates of CU's re-structure of transition support and resources for military student community.

CAM 2, a transfer student used Post 9/11 military education benefits to major in Political Science and Pre-Law. He was happy with his academic progress, attended school full time and wanted a future as a politician in Washington, D.C. after graduation in 2016. His service was in the Air Force and Army. CAM 2 was married and the father of two children. His length of time since separation from the military to college enrollment was three months.

CAM 3, was a transfer student who served in the Air Force. He received VA education benefits and was enrolled full time in the RBA program. Happy with his academic progress in college, he wanted to "have a great future." He was single with no children. His length of time since separation from the military to college enrollment was five months.

CAM 4, served in the Army and received GI Bill education benefits. As a transfer student, he was happy with his academic progress at CU and planned to graduate in spring, 2015. Top was enrolled in the following majors: Biology, Wildlife Management, and the RBA program. Married with children, his future plans included a master's degree in Health 
Promotion. His length of time since separation from the military to college enrollment was four years.

CAM 5, age 44, was happy with his academic progress as a full time student, majoring in education. He was discharged from the Army and received Voc Rehab military education benefits after transferring to CU. Divorced with children, his future plans were to pursue a career in Major League Baseball following graduation in 2017. He didn't specify the length of time between separation from the military and college enrollment.

CAM 6, age 26, served in the Marine Corps. As a full time transfer student, he used Chapter 33 military education benefits to major in Sports Administration and planned to graduate in fall 2015. Single with no children, his future plans included a career in Major League Baseball. He was happy with his academic progress. His length of time since separation from the military to college enrollment was two years.

CAM 7, age 31, served in the Army and received Vocational Rehabilitation (Voc Rehab) military education benefits. As a transfer student to $\mathrm{CU}$, she entered the Regents Bachelor of Arts (RBA) program and attended college full time. Her career goal was to work in a VA hospital following graduation in fall semester, 2014. CAM 7 was divorced with one child. She attributed the delays in her academic progress to poor course advising, which increased her time as an undergraduate student. The length of time between military service and college enrollment was three years.

\section{Presentation and Organization of the Findings}

Narrative text was used to present the findings which were organized according to the four research questions that aligned with those listed in the Focus Group Question Guide (Table 3). Three themes emerged: (1) A military friendly climate is one that is presently beneficial for 
students and develops strategies of support in anticipation of their needs. (2) The quality of transition in a military friendly climate fosters students' success and persistence, prevailing over challenges. (3) Camaraderie is an adaption of the individual veteran's desired support and degree of reciprocal social interaction within the military community on campus (Table 6, 7, 8). 
Table 6

Military Friendly School

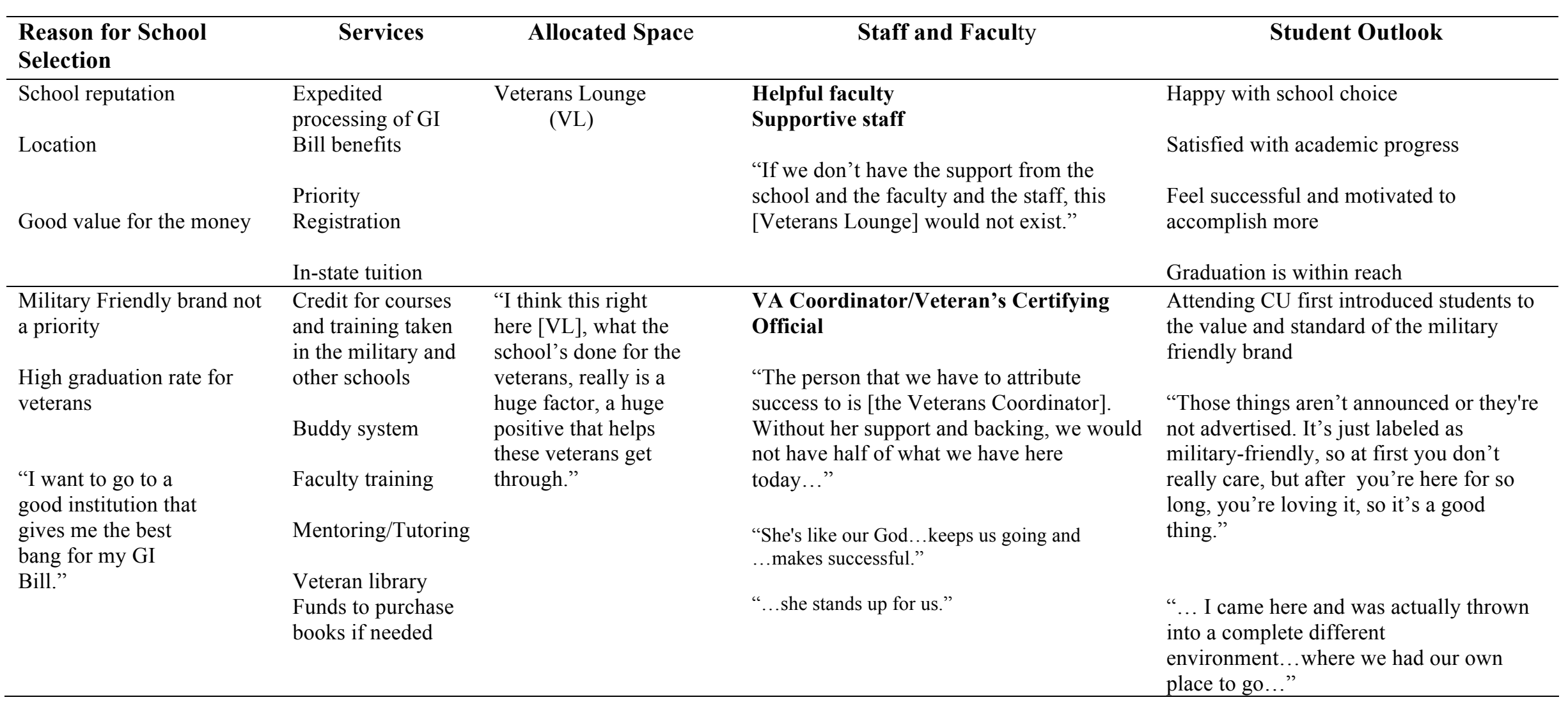


Table 7

Transition

\begin{tabular}{lll}
\hline $\begin{array}{l}\text { The initial } \\
\text { thought process for } \\
\text { most veterans, } \\
\text { "I'm going in for the } \\
\text { education." }\end{array}$ & $\begin{array}{l}\text { Crisis intervention } \\
\text { teams and } \\
\text { modalities }\end{array}$ & $\begin{array}{c}\text { Veterans Office and Veterans Lounge: } \\
\text { Work Study Student Veterans }\end{array}$ \\
\hline & $\begin{array}{l}\text { New curriculum for } \\
\text { veteran's studies } \\
\text { being developed }\end{array}$ & $\begin{array}{l}\text { "When I came here, I didn't have to worry } \\
\text { about it. I had a veteran that used to work } \\
\text { here and [CAM 1] who helped me out and } \\
\text { led me to where I needed to go and get it." }\end{array}$
\end{tabular}

"I didn't know none of this existed, like

[the Veterans Coordinator], someone that helped show me all this, and it's one of the best choices I ever made!"

veteran's studies

led me to where I needed to go and get it." 


\begin{tabular}{|c|c|c|c|c|}
\hline $\begin{array}{c}\text { Timeframe } \\
\text { Military } \rightarrow \text { College }\end{array}$ & Positive & Negative & Lone Wolf & Best Part of Transition \\
\hline $\begin{array}{l}3 \text { months } \\
5 \text { months } \\
2 \text { years } \\
3 \text { years } \\
4 \text { years } \\
7 \text { years }\end{array}$ & $\begin{array}{l}\text { Credit for: } \\
\text { - courses } \\
\text { taken at other institutions } \\
\text {-military experiences and } \\
\text { training }\end{array}$ & $\begin{array}{l}\text { "I think if I would've had better advising, I } \\
\text { probably would've graduated by now." } \\
\text { "I hate it when teachers talk to you like } \\
\text { you're } 19 \text { or } 20 . \text { You go to them with an } \\
\text { issue, or maybe you might have to miss } \\
\text { class, and they come at you like you're a } \\
\text { 19-year-old kid, all sarcastic, that really } \\
\text { doesn't sit well with me." }\end{array}$ & $\begin{array}{l}\text { Time frame of reintegration is } \\
\text { questionable, varies by the } \\
\text { individual } \\
\text { Absence of formal/informal support } \\
\text { "Some people are still fighting } \\
\text { those demons." }\end{array}$ & $\begin{array}{l}\text { "This lounge is the best thing about } \\
\text { school." } \\
\text { "It's one team, one fight type of } \\
\text { atmosphere." }\end{array}$ \\
\hline \multirow[t]{3}{*}{$\begin{array}{l}\text { *One person did not indicate } \\
\text { timeframe }\end{array}$} & $\begin{array}{l}\text { Early registration and } \\
\text { testing } \\
\text { " They took a lot of } \\
\text { military experience which } \\
\text { put me up to a senior } \\
\text { level." }\end{array}$ & $\begin{array}{l}\text { "Age. We're dealing with all these straight } \\
\text { out of high school kids, and they look at } \\
\text { you, "What the hell are you doing in } \\
\text { school?" }\end{array}$ & $\begin{array}{l}\text { "When I got out, it took me a } \\
\text { while. I'm on medication, and if } \\
\text { it wasn't for the medication, I } \\
\text { wouldn't be here. I would } \\
\text { probably be curled up in the } \\
\text { corner shivering and wet." } \\
\text { Difficulty with re-assimilation }\end{array}$ & $\begin{array}{l}\text { "When the person walks through the door } \\
\text { it's like they're home, and I'm very } \\
\text { grateful. That's what got me through } \\
\text { school. Without this here, I wouldn't } \\
\text { have made it." }\end{array}$ \\
\hline & $\begin{array}{l}\text { "Teachers are pretty good } \\
\text { about dealing with us." } \\
\text { "We have developed so } \\
\text { many programs here to } \\
\text { make their experience here } \\
\text { at Concord a positive } \\
\text { one." }\end{array}$ & $\begin{array}{l}\text { "I've experienced issues where professors } \\
\text { think that their position of authority gives } \\
\text { them the right to be judgmental when it's } \\
\text { not necessary. I've had to step in and correct } \\
\text { a few of them at times." }\end{array}$ & $\begin{array}{l}\text { Subjected to Triggers } \\
\text { - history - -experiences - } \\
\text {-intrusive thoughts } \\
\text { - excessive anxiety because of re- } \\
\text { association } \\
\text {-painful memories }\end{array}$ & $\begin{array}{l}\text { "Getting in the lounge and doing our } \\
\text { studies. I still ask [CAM 1] or some of } \\
\text { the other veterans for help with projects } \\
\text { or homework." }\end{array}$ \\
\hline & $\begin{array}{l}\text { "Concord has been } \\
\text { fabulous! I recommend } \\
\text { Concord to anybody." } \\
\text { "The school is helping us } \\
\text { achieve our goals." }\end{array}$ & & $\begin{array}{l}\text { "Before I even started school, } \\
\text { the first thing I did I got on my } \\
\text { bike. I wanted to ride a couple } \\
\text { thousand miles. I had to } \\
\text { decompress. A lot of vets got to } \\
\text { do that. We call it the lone } \\
\text { wolf." }\end{array}$ & $\begin{array}{l}\text { "What we say in here doesn't go outside } \\
\text { these walls. We can say our piece, get it } \\
\text { off our chest, then laugh, joke about it. } \\
\text { Next thing you know, it's all good." }\end{array}$ \\
\hline
\end{tabular}


Table 8

Camaraderie/Veterans Lounge

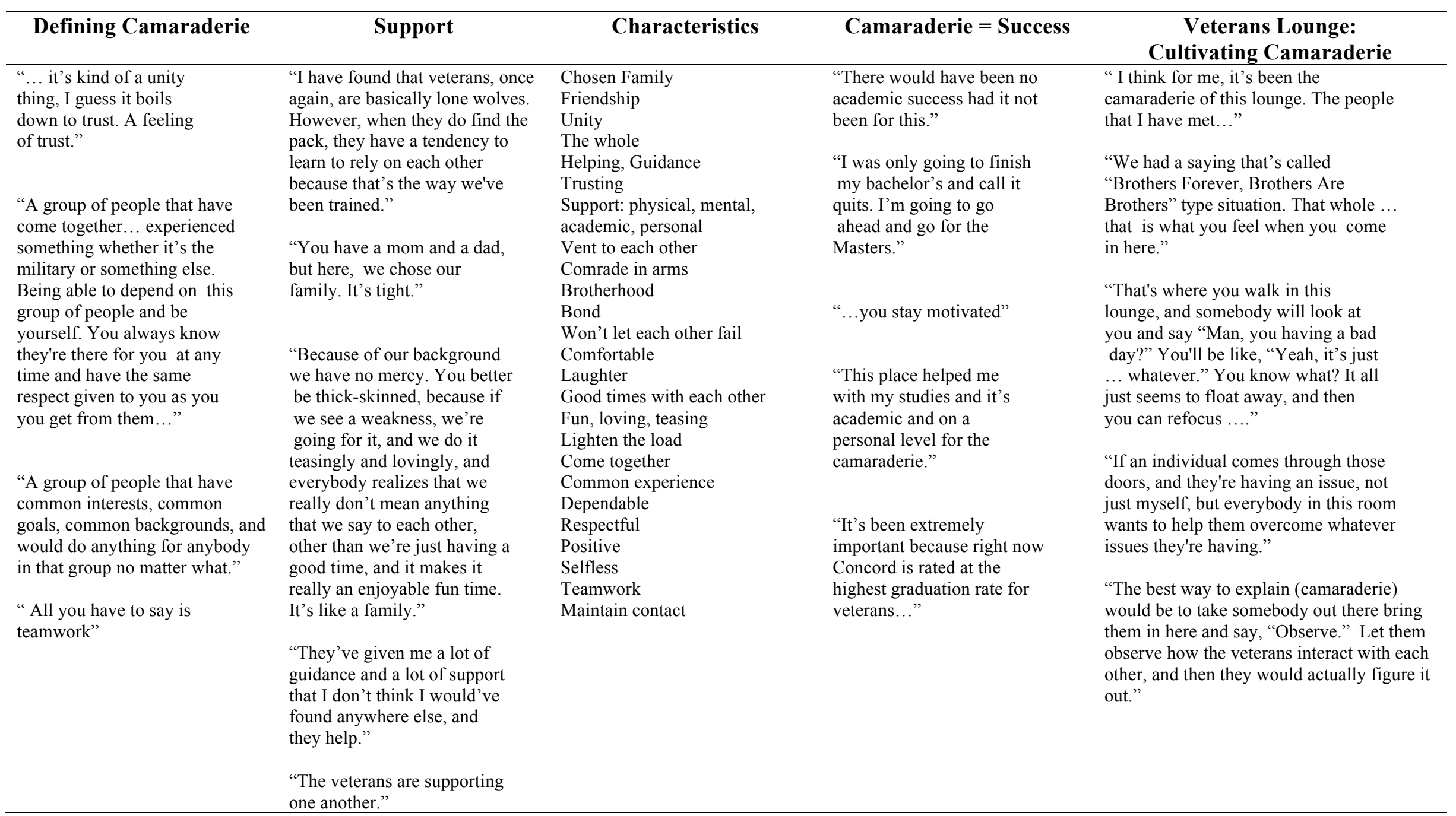


"We won't let each other fail.

If we see somebody having

issues we approach that."

"I have the VA crisis line -

stickered all over my house.

have other sources of phone

numbers. When I was in a

group in Georgia, I still have

their numbers and contacts,

my Vietnam veteran friends

who's in my PTSD group

down there, and I've been in

PTSD groups up here. So I

do have my support, and I

have my support right here." 


\section{RQ1-A: What are student service members' and student veterans' perceptions of their military friendly campus?}

Guide1. What are your thoughts about a college or university that identifies itself as being a military friendly school?

The focus group convened at the Veterans Lounge. It was a central location that represented the institution's commitment to military friendly policies and a physical manifestation of student support and resources. It was central to students' transitions experienced at $\mathrm{CU}$, and especially significant for the six veterans in the group who had transferred from other colleges and universities. Their awareness and appreciation of a military friendly climate substantially increased over time, as they persisted in their studies. It was not a priority in their motivation to attain a college degree at first.

Among student veterans in the room were two military dependents who attended CU. One had a father who served in the military and the other person's husband was a veteran. Their sponsors were not present that day. The women were briefed on the sample criteria for research participation which was restricted to students with military experience. The veterans had no objections to their presence during the focus group discussion which proceeded as scheduled. The women did not stay for the entire group discussion. Their comments were not used in this report.

As a veteran, student, and staff member working in the Veterans Office, these roles were especially meaningful to CAM 1 , which influenced his dedication to advocate the essence of military friendliness and to ensure CU's success in this undertaking. CAM 1:

My job here is to develop a pathway for success to ensure that if a road block is developed 
we can get around that and overcome it. To be able to go on and meet their goals, that's what we've done here so far. There's always room for advancement. There's always room for improvement. We have developed so many programs here to make their [veterans/dependents] experience here at Concord a positive one.

\section{CAM 6:}

I came from a school that did not have a very strong veteran's program at all. It was basically the veteran's office. It was there to make sure your GI Bill went through. That's pretty much all they were there for. There was no other network on campus and then I came here and was actually thrown into a completely different environment. We had our own place to go. We had the commonality of being veterans and just getting together where the student body out side would not really bother us. The expectation actually got set here.

\section{CAM 3:}

Initially, I didn't care. I didn't bother with that. I went to another school and I didn't have it. It's something I never experienced, so I didn't lose it. But after going here I was definitely looking for one but prior to coming here it didn't matter.

\section{CAM 4:}

I came from a different school. They actually had a house separate for the veterans but nobody really cared, and they didn't push it. My first year at my first school, I didn't want nothing to do with veterans. I was like I'm out now, I'm retired. I don't really care about the war stories and all of that. I'm trying to get on track education-wise. So that whole military-friendly to me was more like make sure you can process my GI Bill and pay on time. At that point, that's what I cared about. I think for a lot of new vets initially that title does not mean a whole lot because they're looking at it more as, I'm going to school to go to school. 
My first half-semester I was here, I didn't come in because I wasn't coming here for the veteran part. I was coming for the education. I spent most of my time in the library. I just kind of stumbled on this [Veterans Lounge], and thought this is a nice place to be, get away from the crowd and hang with other veterans. Now I think it does make a difference, and it's important.

CAM 2:

This is my second semester here. Concord has been fabulous! I recommend Concord to anybody. This summer I have to go to Ohio for a class. I'm trying to get everything done with the VA through the financial aid department there which has been frustrating. There's no communication. If its higher education and veterans attend, there should be a veteran's rep to assist in their goals. It didn't make any sense. I mean, you're at the same school but there was no communication. When I came here I didn't have to worry. I had a veteran that used to work here, and CAM 1 who helped me out. They led me through what I needed and where to go and get it.

Guide 1a. How important is the military friendly brand to you as a student?

The military friendly brand could be construed as an advertising gimmick by some. It did not impact college selection. School location, environment, and education quality were decisive factors instead. Students reported the standard for the military friendly brand was developed at CU because the school surpassed the minimal requirement of processing GI Bill funding for the military student population. The Veteran's Representative had a significant impact on students' adjustment to the campus culture. Institutional support included services and key personnel that assisted students with meeting their individual needs.

CAM 7: 
When you talk about the advertisement for a military-friendly school a lot of people don't really understand that so they don't put a lot of emphasis on it. After being here, I came to understand a couple of the dynamics about it. We have a counselor from the Vet Center in Princeton, that comes and gives counseling to all of the professors on how to interact with veterans during a crisis and the steps to take when a situation arises. Those things aren't announced or advertised. It's just labeled as military-friendly. At first you don't really care, but after you're here for so long you're loving it, so it's a good thing.

\section{CAM 4:}

I don't think it really gives any value or gain to at all in my mind. It's somewhat used as an advertising gimmick. Concord, compared to my last school in treating veterans is $100 \%$ above. It's a great school. When you drive in and walk up, you see the five seals [Air Force, Army, Coast Guard, Marine Corps, Navy] showing military, veteran-friendly, all that great stuff and that sounds great. A lot of schools are starting to pick up on that. They say hey, look, we love our vets, we're military friendly. But you have to look at the totality of what's going on with that school. Concord, I think, can really lay claim to they're a veteran friendly campus.

It's very easy to say, I'm veteran-friendly. I'm processing your GI Bill and technically we're veteran-friendly. I think it depends on to what extent they go with it. A lot of schools just throw it up there. For the person getting out [of the military] I don't think that's really a big decision-making point for them. It wasn't for me, and a lot of guys I talked to. It wasn't that way at all. They weren't looking for that red seal of approval. They're like I want to go to a good institution that gives me the best bang for my GI Bill bucks and get an excellent education. I'm going to come out with my degree. That's usually the initial thought process for most veterans. They're looking at I'm going in for the education. 


\section{CAM 3:}

I think some people look at the area. I don't think before here the military had anything to do with it for me. I basically just said okay, can I live in this are? Can I adjust to this area? Is this a fun area? I didn't want to go to WVU. I didn't want to go to Marshall. I didn't want to be in the city so the surrounding area was my biggest factor, the location. Going back to veteran-friendly I didn't know none of this existed, the [Veteran Coordinator/Certifying Official] was someone that helped to show me all this [Veterans Lounge/services/resources]. It's one of the best choices I ever made!

Guide 6. What would you like to see your school do for military and student veterans on campus?

The discourse among focus group members revealed that some were not aware of all the resources and courses implemented in recent years with student service members in mind. There were no new suggestions made at the meeting as CU had essentially addressed concerns students typically requested.

\section{RQ1-B: What are student service members' and student veterans' academic success and transition from the Armed Forces to higher education in relation to their perceptions of military friendly campus climates?}

Guide 2. Please tell me about your transition from the military to college.

The path to college from the structured lifestyle of the military culture was seldom linear for these non-traditional students. The diversity of their military and civilian experiences 
determine the timeframe of separating from the military and starting college full time, their motivation to enroll, and acclimation to student life. Two veterans were first-generation college students. They would be the first in their families to graduate with a bachelor's degree.

Transition was reported as being positive at CU as it presented a climate that advanced students' academic and professional goals. Staff members and faculty were perceived as being helpful. CAM 1:

I retired from the Navy, after I retired from that, I went into the corporate world, retired from that too. This is another bucket list for me, something that I just had to achieve personally. What I want to do, my vocational choice is to be able to work for veterans that are suffering posttraumatic stress disorder and see if I can't help alleviate some of that stress.

CAM 2:

I just got out in February of last year (2013). I'm on a temporary retirement list. I'm planning on getting my Ph.D. in political science then my J.D. degree. That's as long as my medical condition allows me. I was recently diagnosed with multiple-sclerosis.

\section{CAM 7:}

I was in the Army for six years. I'm originally from Texas, and moved here for my exhusband. No one in my family has ever been to college, so I guess I'm the first one. I started at one school and then transferred here. It's been pretty easy.

\section{CAM 3:}

I had a heck of a run. Let me condense this and keep it PG. I got out in 2007.

It was before the new GI Bill which was not near as good as the current one. I went to school, bartended, did some other things, struggled through, and got a couple of Associate degrees. Started working on the ground making good money. The market kind of tanked. I had some 
months left on my GI Bill and like her [CAM 7] none of my family was educated. I'm the only one with an Associate degree, and will be the only one with a Bachelor's which kind of led me in this direction.

CAM 4:

One thing about getting out of the military, although I had a great experience and not bitter at all the last thing you want to see or be related to is anything in the military. Twentytwo years in the Army, most of it at Ft. Bragg and a lot of deployments in different units. When I got out, I wasn't really sure [what to do]. I didn't think I was going to go to school.

I realized that I needed to do something. I went to a different school first. I'll be honest with you it was a transition for me! I came out of a very structured [environment] being a senior non-commissioned officer. I was used to a different set of rules. I had to really learn to relax. Now I can enjoy life and enjoy school. It was a bit of a transition but I do enjoy it and will be graduating pretty soon.

\section{CAM 5:}

I got out of the Army in 2008 after 21 years and a bunch of deployments. I went to work for the Virginia Department of Corrections. I worked there about five-and-a-half years and decided to do something else. I came down here to Concord because I grew up in Athens. I thought it would be a good place to go. When I got here, I ran into [CAM 1] right away and tried to get paperwork done. The school was very helpful to get registered ahead of time and testing done. They took a lot of military credits which put me up to a senior level. I did not have to take any electives and they even took some of the core courses for education. I came in with 130 hours. So Concord's actually been very helpful, easy to get around and all the teachers are pretty good about dealing with us. 
Guide $2 \boldsymbol{a}$. Is there one positive college experience you'd like to tell us about?

Students found the Veterans Lounge to be the hub where all things positive evolved. It was a centralized location where the cohesiveness of group members cultivated a form of camaraderie that stemmed from military service. This bond supplemented college life. For some, it was similar to a strong family they chose to be a part of. They readily found support and help, assistance from the work study veterans and Veterans Coordinator, and the resources they needed. Their experiences in the Veterans Lounges was also filled on frequent occasions with recurrent light-hearted humor and laughter in the process that alleviated academic and personal anxieties.

CAM 7:

This lounge is the best thing about school!

\section{CAM 4:}

It's been the camaraderie of this lounge and the people I met. When a person walks through the door it's like they're home, and I'm very grateful. That is what got me through school. Without this here, I would've not made it. There would've been no academic success had it not been for this.

\section{CAM 2:}

At the same time it's one team one fight type of atmosphere just by coming to the lounge. For me with my memory issues, I still ask CAM 1 or some of the other veterans for help on some of my projects and homework.

Guide $2 \boldsymbol{b}$. Is there one negative or challenging college experience you'd like to talk about? 
Despite personal challenges student veterans encountered in some of their relationships with traditional-age students and faculty, they persisted in their studies. One student attributed the poor quality of academic advising she received likely delayed her progress toward degree attainment.

CAM 7:

A challenge that I found with school is dealing with civilian people. I have a pretty low tolerance of younger students. That's been a roadblock and I think I'm overcoming that. A big problem that I've had is advising, really bad [academic] advising. I think my time here has been lengthened because of it. I probably would have graduated by now with better advising. I had a really good advisor at first and he ended up dying and then it's just been a downhill spiral.

CAM 2:

Age, because we're dealing with all of these straight out of high school kids. They look at you as if to say, "What the hell are you doing in school?" I've seen it several times and have been laughed at.

CAM 4:

I hate it when teachers talk to you like you're 19 or 20. You go to them with an issue or maybe you have to miss class and they come at you like you're a 19-year-old kid, all sarcastic. That really doesn't sit well with me. I don't like that. I'm 30 years old. I don't need a sarcastic come back for why I'm leaving your class.

\section{CAM 5:}

I've experienced issues where professors think that their position of authority give them the right to be judgmental when it's not necessary. I've had to step in and correct a few of them at 
times. That's the only bad issues I've had, nothing more. I think most of it is miscommunication on their part. They just needed to be educated and I was willing to do that for them.

Guide $2 c$. In what way does a military friendly school help you to graduate?

For the most part, the top-down support network involving administrators, faculty and staff members were recognized and valued by student veterans. Some students especially held the Veterans Coordinator in high regard, and ascribed their success in school was due to her support.

Among the courses and resources implemented at CU of interest to students with military background were: priority registration, in-state tuition, Battle Buddy system (in place for two years), Post-Traumatic Stress Disorder (PTSD) and Crisis Management Intervention classes and modalities (open to the general student population). These classes were instructed by a teacher with 38 years of experience in PTSD counseling. Course material covered various kinds of trauma in addition to combat-related distress and events. New curriculum planned for the future such as Veterans Studies would register veterans and civilian students.

CAM 2:

Concord has the highest graduation rate for veterans so that ought to say something. The school is helping us to achieve our goals.

\section{CAM 4:}

I think this right here [Veterans Lounge] is really helpful. The key is that people of different backgrounds can come together. They can vent. What we say in here doesn't go outside these walls. We can say our piece and get it off our chest then laugh and joke about it. Next thing you know it's all good. Then you come back again and stay motivated. I was only going to finish my Bachelor's degree and call it quits. I'm going to go ahead and go for the Master's. This is a good school and I like the people here. 
CAM 1:

If we see somebody having issues, we approach that person. What can we do to assist you? What are you having issues with? Is it physical, mental, or academic? Let us provide you with the services that you need to ensure you meet your goals. They know that they can come in here [Veterans Lounge] and whatever they say in here stays in here.

We have a library where they can get books for free. They just turn them in when they're done and use them when they need them. If they don't have the funds to buy all the books they needed we'll find a way to get them. We have a tutoring program, mentoring program and crisis intervention teams that are here to help them. My goal is if I can help one person then everything I've done has been worth it.

If we didn't have the support from the school, the faculty and the staff, this [Veterans Lounge] would not exist. The person that we have to attribute that success to is the [Veterans administrator]. Without her support and backing we would not have half of what we have here today. She has brought the success of this lounge and this veteran's community to the forefront.

CAM 2:

She stands up for us.

CAM 7:

She's like our God. She keeps us going, and she is what makes us successful.

\section{RQ2-A: What are student service members' and student veterans' perceptions of camaraderie among military peers at military friendly campuses?}


Guide 3. If you had to explain camaraderie to a civilian what would you say?

Descriptors of camaraderie varied among students. They were in agreement that the camaraderie they shared in college extended into their personal lives. They maintained contact with veterans no longer at $\mathrm{CU}$ and planned to be in touch with each other after graduation. One student determined that camaraderie was not easily understood by civilians.

\section{CAM 3:}

I feel like it's kind of a unity thing. It boils down to trust, a feeling of trust. Texas:

A group of people that have come together that have experiences in the military. You can be yourself and depend on each other. You always know that they're there for you at any time and have the same respect given to you as you give them in a positive way.

\section{CAM 5:}

A group of people that have common interests, goals, and backgrounds. They would do anything for anybody in that group no matter what. If they needed something and you had it, you would give it to them no matter what. This doesn't always happen outside of here [Veterans Lounge]. The best way to explain would be to take somebody out there and bring them in and say, "Observe." Let them observe how the veterans interact with each other and then they would actually figure it out.

Most times it's hard to explain something they've never experienced because most of them don't. The closest thing they've got to the experience is maybe on a football team but once they got off that football team they don't interact with anybody else on that team again. CAM 2:

Teamwork. All you have to say is teamwork, just as long as you don't stab one of them 
in the back.

Guide 5. What could be a reason that some military members or veterans don't associate with their military peers or say they don't know of other students on campus with military experience?

An aspect of transition that impacted camaraderie among veterans in college was the Lone Wolf. These service members' transitions from the military was associated with the duration of time each individual determined was effective to manage the scope of experiences gained in the Armed Forces, and their comfort level of engaging with others in society during reintegration.

\section{CAM 3:}

For a lot of military people once they get out of the military, it's kind of the lone wolf feel. I don't really know how to explain it outside of the military. It's just a feeling you have. CAM 1:

Triggers, things that recall intrusive thoughts and excessive anxiety because of reassociation. You'll see that occur. Trigger past histories. Some people are still fighting those demons. They have to be able to find a way to overcome before they can re-assimilate into groups.

CAM 2:

When I got out, it took me a while. I'm on medication, and if it wasn't for the medication I wouldn't be here. I would probably be curled up in the corner shivering and wet. CAM 4:

For especially new veterans, they've got to decompress. I had to decompress before I even started school. I got on my bike and wanted to ride a couple of thousand miles. I had to put 
a lot of stuff down. A lot of vets have to do that. We call it the lone wolf. When I hear about a new cat on campus and they're a vet doing that lone wolf I don't have a problem with it, because I've been there. Everybody has different experiences, no time frame [to decompress].

Somebody could come off of a rotation in Iraq and literally in three days they just let it wash off. Another person in that same squad could come off that same rotation and it may take years. We let them deal with it and when people need help or show signs they need help then we can say, "Hey, you want to talk buddy? How are things going?" It depends on the individual. You just give people time once they have that time this place [Veterans Lounge] is always open. They can come in, relax and feel like they're part of the family.

\section{RQ2-B: What are student service members' and student veterans' academic success and transition from the Armed Forces to higher education in relation to their perceptions of camaraderie among military peers?}

Guide 4. How important is camaraderie to staying in college, graduating and attaining your degree?

Both student veterans and military dependents used the Veterans Lounge when they're on campus. This was a dedicated space in keeping with CU's proactive military friendly stance and the site of frequent student engagement and interaction. Veterans credited their relationship with each other as being personally and scholastically beneficial, conducive to their achievements in academia.

CAM 1:

I have found that veterans, once again, are basically lone wolves. However, when they do find the pack they have a tendency to learn to rely on each other because that's the way we've 
been trained. We won't let each other fail. If an individual comes through those doors, and they're having issues everybody in this room wants to help them overcome whatever issues they're having.

You better be thick-skinned because if we see a weakness we're going for it and we do it teasingly and lovingly, because of our background we have no mercy. Everybody realizes that we really don't mean anything that we say, other than we're just having a good time. We're trying to lighten the load and it makes it really an enjoyable, fun time. It's like a family. CAM 7:

It was survival for me as a poor, single parent. They've given me a lot of guidance and a lot of support that I don't think I would've found anywhere else and they help. This place helped me with my studies. It's on an academic and personal level for me with the camaraderie.

\section{CAM 5:}

I think the biggest thing is when you've got an issue in class. You just come to vent. The other day I wanted to choke a student teacher just because he's never been outside of school but he's trying to telling me what subject I should want to research. I'm like, just looking at him. I'm getting better about not just reaching out and grabbing his throat which was a big step because I really did want to choke this kid out, and I didn't. So this is a great place.

\section{CAM 4:}

Everybody's different. I don't think there can really be a blanket answer. You have to look at everybody's circumstance individually. I think as far as getting through, I think this right here [Veterans Lounge], what the school's done for the veterans really is a huge factor, a huge positive that helps these veterans get through.

I know at my last school, a lot of veterans passed out. They did for so long. I had a good 
friend who had been in the Marine Corps. He had all these plans and he just slowly kind of faded out of them. Next thing you know, he just said, “Nah, I'm done with it, bro. I can't do this anymore." The school itself was labeled as a veteran-friendly school. It didn't really put the effort into the veterans as Concord does, that sense of comrade and brotherhood.

We had a saying that's called "Brothers Forever, Brothers Are Brothers" type situation. That is what you feel when you come in here. We can have our personal disagreements. We all have our disagreements at times, but it's like a family. Like the one person said, you have a mom and a dad here. We chose our family. It's tight.

Veterans or our veteran dependents can come in here (Veterans Lounge). That's the key right there. No matter how bad the day can be because you're going to have bad days here. It happens. I'll come and talk about a bad day and think "Why am I even bothering with this?" That's when you walk in this lounge and somebody will look at you and say, "Man, you having a bad day?" You'll be like, "Yeah, it's just ... whatever." It all just seems to float away and then you can refocus and you can say, "You know what? Bag it. I'm not even going to worry about it. I have something else to focus on." It's a good group that we have here, so I'm going to stick with them to pursue my education.

The humor illustrated between participants also served another purpose, in this instance it served to inform a student veteran about a support measure she felt was needed at CU and was not aware that it had been implemented.

\section{Facilitator: What would you like to see Concord do for military students on campus that hasn't already been done?}


CAM 7: I don't even know if it's possible or not, but to assign a buddy, because in the military you have a battle buddy, that's your person that you stay with, when you get to college, you don't have that. I think they could establish some sort of battle buddy system...

CAM 2: $\quad$ Right there.

CAM 1: $\quad$ We've been doing that now for about two years.

CAM 7: $\quad$ Really? Well, you all failed me.

CAM 1: $\quad$ You thought we were just following you. (Laughs)

CAM 4: $\quad$ Some of us were, but that's beside the point. (Laughs)

Students' camaraderie had strengthened over time in addition to their common bond of having military experience which had now been fortified into a bond of family particularly at CU.

CAM 4: $\quad$ You have a mom and a dad, but here, we chose our family.

\section{Facilitator: You chose your family? Does it matter, Texas, that you are a female?}

CAM 7: $\quad$ I kind of enjoy being around the guys...

CAM 4: $\quad$ She's more of a guy than we are sometimes, which is kind of scary. (Laughs)

CAM 7: $\quad$ But I have a boyfriend and all that stuff.

CAM 2: $\quad$ Oh, you wanted to get that on tape. (Laughs)

CAM 1: $\quad$ Yeah, had to get that on ... (Laughs)

CAM 7: I feel completely comfortable with all of these guys...they are my family because I don't have a family here, so they're my family. 


\section{WFINTO Survey}

The demographic information was first presented and followed by the relevant details that corresponded to each of the four research questions. There were 198 respondents that started the survey and 170 completed it with a 14\% dropout rate. Respondents were not required to answer all questions. This option resulted in varying degrees of sample size pertaining to some questions and consistent with the $86 \%$ overall number of respondents $(N=170)$ that submitted the online survey.

More males $(n=127)$ took part in the study $(75 \%)$ compared to females $(n=43)$ who comprised $25 \%$ of the total respondents $(N=170), M=1.75, S D=0.44$, Variance $=0.19$. Students' military profile indicated they represented all branches of the U.S. Armed Forces. The highest number of respondents $(n=34)$ served in the Army and the fewest in the Coast Guard $(n=3)$ (Table 9). 
Table 9

Military Profile: Active-Duty, Mobilized, Deployed Service Members and Veterans

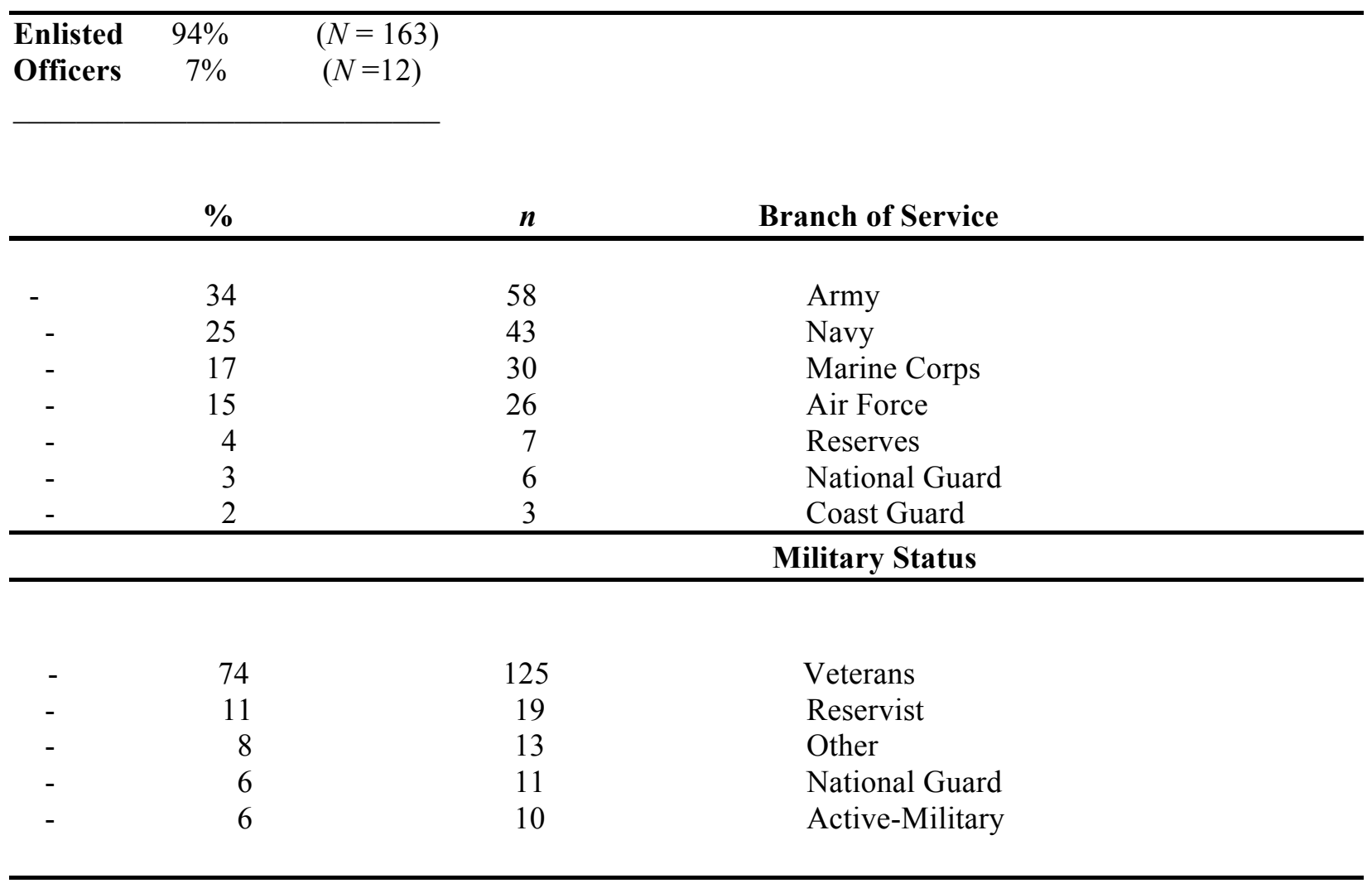

One hundred sixty-three respondents were in the enlisted ranks (94\%) and 12 service members were officers $(7 \%)$. More student veterans $(n=125)$ completed the survey compared to active-duty, mobilized and deployed service members including those retired from military service (Table 10).

To an extent, the diversity of respondents $(N=170)$ reflected the larger U.S. population. Caucasian students $(n=124)$ completed $73 \%$ of the surveys (refer to Table 4$)$. Those that selected the Multi-racial category identified themselves as: mostly White; Asian/Indian of African descent; White / Filipino; Black/Hispanic; White/Native American; Portuguese; White/ 
Black/Indian/French; Polish/Mexican. Two people selected Other and wanted to be distinguished as American Indian, human.

Table 10

The Diversity of Military Members and Veterans

\begin{tabular}{cccccccc}
\hline Caucasian & Hispanic & Native American & Multi-racial & Black & Mexican & Pacific Islander & Other \\
\hline 124 & 23 & 9 & 9 & 5 & 4 & 4 & 2 \\
$73 \%$ & $14 \%$ & $5 \%$ & $5 \%$ & $3 \%$ & $2 \%$ & $2 \%$ & $1 \%$ \\
\hline
\end{tabular}

Student service members' and student veterans' marital status indicated that $51 \%$ were married $(n=87), 30 \%$ single $(n=51), 11 \%$ divorced $(n=19), 5 \%$ never married $(n=9), 2 \%$ separated $(n=3)$, and $1 \%$ reported as widow/widower $(n=1)$. Out of 170 respondents, $50 \%$ of students $(n=85)$ indicated they had children and $50 \%$ of the sample $(n=85)$ had none. Fifty eight percent of service members and veterans had a father $(n=54)$ or a mother $(n=45)$ who was a college graduate with a bachelor's degree. About $30 \%$ of this subpopulation were firstgeneration college students.

As nontraditional students, service members and veterans $(n=169)$ were categorized into six age groups. The most respondents $(n=86)$ were in the $25-34$ years, younger-non-traditional age group. Only 18 students in the youngest-non-traditional group were similar in age to many civilian, traditional college students (Table 11). 
Table 11

Non-traditional Age Categories of Students with Military Experience

\begin{tabular}{lcc}
\hline \multicolumn{1}{c}{ Age Categories } & Frequency & \% \\
\hline 25-34 years, younger-non-traditional & 86 & $51 \%$ \\
35-44 years, non-traditional & 18 & 25 \\
18-24 years, youngest-non-traditional & 18 & 25 \\
45-54 years, older-non-traditional & 16 & 9 \\
$55-64$ years, oldest-non-traditional & 6 & 4 \\
\hline
\end{tabular}

The respondents $(N=169)$ were from seven military friendly universities and colleges located in various geographic regions of the United States with 59\% from Arizona. Students were requested to indicate the state they were enrolled in college courses and not required to identify the name of their school. In some cases students referred to their institution by name in the open-ended questions or in the Other, Please Specify categories of multiple-choice answers (Table 12).

Table 12

State Locations Of Military Friendly Universities and Colleges

\begin{tabular}{lcc}
\hline State & Frequency & \% \\
\hline Arizona & 99 & 59 \\
West Virginia & 34 & 20 \\
Hawaii & 20 & 12 \\
California & 9 & 5 \\
Pennsylvania & 4 & 2 \\
Minnesota & 2 & 1 \\
Virginia & 1 & 1 \\
\hline
\end{tabular}




\section{Research Question 1-A: What are student service members' and student veterans' perceptions of their military friendly campus?}

Popular websites service members and veterans $(N=42)$ accessed to seek college information and help guide school selection of military friendly institutions were U.S. News \& World Report ( $n=13)$, G.I. Jobs $(n=10)$, Militaryschools.com $(n=8)$, Military Times $(n=7)$, and Military Advanced Education $(n=4)(M=4.31, S D=2.18)$ (Figure 2). Seventeen chose the Other category to list websites they preferred such as: VA.Gov Education, http://www.goarmyed.com, and university/college websites.

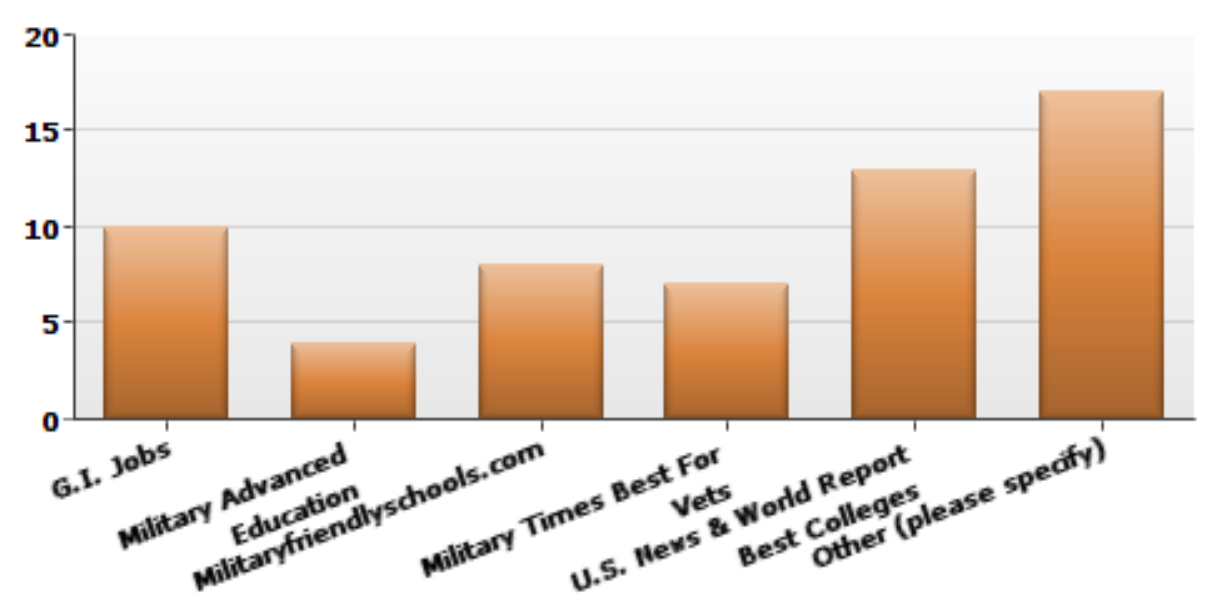

Figure 2. Popular websites service members and veterans seek college information

Over $7 \%$ of military members and veterans reported the Military Friendly brand/logo posted on a college or university website had very little influence on their school selection. On the other hand, having the endorsements of popular websites and being designated as Military Friendly impacted $24 \%$ of students' decision to enroll in an institution. For the most part their choices were based on various factors such as location, which was a primary consideration for 
$65 \%$ of students and affordability (31\%) $(M=6.00, S D=2.76)$ (Figure 3$)$.

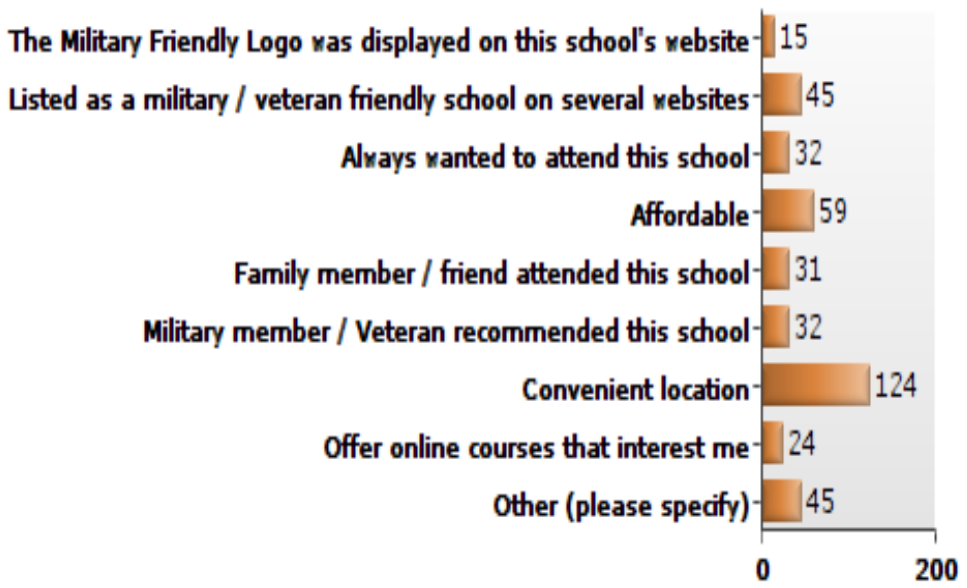

Figure 3. Factors of School Selection

A school's processing of VA Education benefits was a priority for $84 \%$ of service members and veterans and having access to an Office of Military/Veterans Affairs on campus was reported by $76 \%$. A dedicated space was available at $51 \%$ of colleges and universities. Improvements were called for in the following areas: college credit, priorty registration, academic advising, counseling and therapy, waivers, mentoring, and set up of a buddy system (Table 13). 
Table 13

Services and Resources Currently Available at Military Friendly Institutions

\begin{tabular}{rcc}
\hline Services and Resources & $\boldsymbol{n}$ & $\mathbf{\%}$ \\
\hline Process VA Education Benefits & 157 & 84 \\
Office of Military / Veterans Affairs & 143 & 76 \\
Veterans Lounge / One Stop Center & 96 & 51 \\
Scholarships / Grants / Fellowships for military members and veterans & 92 & 49 \\
Veterans Advocate & 88 & 47 \\
In-State Tuition & 86 & 46 \\
Easy to use school website (contact and information) & 86 & 46 \\
College credit for courses taken during military service and training & 82 & 44 \\
Priority Course Registration & 81 & 43 \\
Sellow Ribbon & 81 & 43 \\
Student Veterans Chapter & 80 & 43 \\
Career Counseling & 79 & 42 \\
Academic Advisor experienced in helping military members and veterans & 58 & 31 \\
Waive/relax Application Deadline for deployed military members & 38 & 20 \\
Separate Orientation session & 36 & 19 \\
Counseling and Therapy (PTSD, TBI, Depression) & 35 & 19 \\
Waive Application Fees for military members and veterans & 34 & 18 \\
Mentoring program with faculty having military experience & 11 & 6 \\
Buddy system - linking students with military experience & 7 & 4 \\
\hline
\end{tabular}

More than $68 \%$ of the respondents $(N=182)$ indicated they were satisfied with their school's supportive measures implemented on behalf of their subpopulation on campus. Nothing was needed at present or in the foreseeable future. Contradictory to the first group, $32 \%$ specified the essential features they perceived to be needed to improve transition (Appendix B).

A large number of student service members and veterans $(n=152)$ perceived their school to be military friendly and their education goals $(n=102)$ achieved quickly in this climate compared to their professional goals $(n=87)$. Many $(n=148)$ used their GI Bill funds in this climate. Some $(n=64)$ preferred completing their college degrees at a designated military friendly school although others of this subpopulation did not perceive this as being essential to their college commitment (Table 14). 
Table 14

Service Members' and Veterans' Perceptions of a Military Friendly School

Likert Scale Values $\quad$ Strongly Disagree
Frequency
Percent

\begin{tabular}{|c|c|c|c|c|}
\hline \multicolumn{5}{|l|}{ This is a military friendly school. } \\
\hline 1 & 11 & 24 & 73 & 79 \\
\hline 1.00 & 6.0 & 13.0 & 39.0 & 42.0 \\
\hline \multicolumn{5}{|c|}{ Education goals are expedited at a military friendly school. } \\
\hline 5 & 15 & 68 & 56 & 46 \\
\hline 3.0 & 8.0 & 36.0 & 30.0 & 24.0 \\
\hline \multicolumn{5}{|c|}{ Resources, services, and programs available to veterans and military members help me graduate. } \\
\hline 5 & 20 & 36 & 70 & 57 \\
\hline 3.0 & 11.0 & 19.0 & 37.0 & 30.0 \\
\hline \multicolumn{5}{|c|}{ I would not enroll in a university/college that did not identify itself as being military friendly. } \\
\hline 17 & 32 & 75 & 18 & 46 \\
\hline 9.0 & 17.0 & 40.0 & 10.0 & 25.0 \\
\hline \multicolumn{5}{|c|}{ Professional goals to enter the civilian workforce are expedited at a military friendly school. } \\
\hline 11 & 17 & 75 & 59 & 28 \\
\hline 6.0 & 9.0 & 40.0 & 31.0 & 15.0 \\
\hline \multicolumn{5}{|c|}{ This is a military-inclusive campus culture. } \\
\hline 14 & 25 & 72 & 46 & 33 \\
\hline 7.0 & 13.0 & 39.0 & 25.0 & 18.0 \\
\hline \multicolumn{5}{|c|}{ The G.I. Bill is helping to achieve my college education at this university/college. } \\
\hline 9 & 11 & 22 & 28 & 120 \\
\hline 5.0 & 6.0 & 12.0 & 15.0 & 64.0 \\
\hline
\end{tabular}

Student service members and student veterans $(n=133)$ listed their expectations of a Military Friendly University/College (Appendix C). In some instances, the resources and services reflected those already implemented at some schools and found lacking in others. Some students perceived their institution as being military friendly and met their needs during transition. Others raised issues specific to the campus they were enrolled at. The veteran's liaison/advocate/representative was often commended for his/her support and service to students.

A definition for a military friendly school was developed by the researcher based on student service members' and student veterans' comments:

A military friendly school recognizes that military service is significant and accommodates the academic, social, and personal needs of younger and older military 
members and veterans in a transition program that is proactive in maintaining contact with the military student community. It offers fair treatment with no bias in which it is safe and comfortable for military members to walk the campus in uniform. It prioritizes accurate and timely process of VA education benefits and disability claims, having an accessible Office of Military/Veterans Affairs staffed by individuals demonstrating a willingness to be helpful, competent, and knowledgeable about resources, support services, and financial assistance (tuition exemption, grants, scholarships, fellowships, etc.). The institution shows support in accommodating active duty, reserve and guard requirements and provides appropriate flexibility of deadlines and coursework requirements for deployment and special circumstances of military obligation. It promotes the following: priority registration, academic counselors with specialized training to work with military members/veterans, student health counselors, training of administrators, staff and faulty in military student and veteran support, easy transfer of military training and military education to college credits, separate student orientation, in-state tuition, veterans lounge on allocated space on campus, one-stop center, free and accessible parking on campus, student housing, tutoring and mentoring program by faculty/students with military experience, special events and activities during the semester, frequent and updated communication on how to locate services, resources and point of contact on an uncomplicated and easy to navigate website. 


\section{RQ1-B: What are student service members' and student veterans' academic success and \\ transition from the Armed Forces to higher education in relation to their perceptions of military friendly campus climate?}

\section{Transition. Respondents $(N=169)$ reported on their preparation for transition from the}

Armed Forces to the civilian community and college. One of the first things service members did in anticipation of attaining a degree was to first order transcripts of their military courses and training. Many participated in the Transition Assistance Program (TAP) class in the military and quickly applied to colleges and universities. Only a few people sought the guidance of a Military Education Specialist to discuss choosing a college or degree program. A large number of people did not meet with a counselor in the military to discuss the civilian workforce, financial planning, or G.I. Bill benefits (Table 15).

\section{Table 15}

Preparing for Transition from the Military to Civilian Life and College

Likert Scale Values > Strongly Disagree Disagree Neither Agree nor Disagree Agree Strongly Agree Frequency

Mean SD

Ordered transcripts from military courses and training $(N=169)$

$22 \quad 13 \quad 27$

$53 \quad 54$

28.621 .35

Participated in a Transition Assistance Program (TAP) class in the military $(N=170)$

$\begin{array}{lllllll}29 & 18 & 33 & 41 & 49 & 28.37 & 1.43\end{array}$

Applied to colleges and universities as soon as possible $(N=168)$

$21 \quad 30$

$47 \quad 46$

$28.43 \quad 1.36$

Discussed the civilian workforce with a career counselor $(N=168)$

$\begin{array}{rrrrrrr}41 & 44 & 46 & 24 & 14 & 27.56 & 1.23\end{array}$

Met with a counselor to discuss financial planning which includes G.I. Bill benefits $(N=168)$

$\begin{array}{lllllll}44 & 27 & 31 & 37 & 29 & 27.88 & 1.46\end{array}$

Met with a Military Education Specialist to discuss choosing a college or degree program $(N=168)$
59
42
37
15
15
$27.32 \quad 1.28$ 
Student service members and student veterans differed substantially by their chosen time frames to enroll in college courses. Most $(n=40)$ began registering in classes within two years of discharge from military service compared to those $(n=21)$ on active-duty. Respondents who sought out degrees during reintegration within days, weeks, or months opted for brief waiting periods prior to transitioning directly into the college culture. The appeal of attaining a college degree influenced others' decisions to pursue this goal later in their lives, stretching over a span of 6 to 25 years (Table 16).

Table 16

Time frame of Military Service to College Enrollment

\begin{tabular}{lcc}
\hline $\begin{array}{l}\text { MILITARY > COLLEGE } \\
\text { TIME FRAME }\end{array}$ & FREQUENCY & \% \\
\hline 2 years + & 40 & 24 \\
Active-duty & 21 & 12 \\
4-6 months & 20 & 12 \\
1 year & 13 & 8 \\
3 months & 13 & 8 \\
1-2 weeks & 13 & 8 \\
1 month & 11 & 6 \\
2 months & 8 & 5 \\
7-12 months & 8 & 5 \\
3-4 weeks & 7 & 4 \\
6 weeks & 5 & 3 \\
Other & 17 & 10 \\
Years 25, 15+, 10, 7, 6 & & \\
Days 4,3 & & \\
\hline
\end{tabular}

Over $50 \%$ of the influx of service personnel and veterans $(n=88)$ transferred from other colleges and universities. About 15\% began their higher education trajectories as freshmen $(n=26)$ and persisted at the same school throughout their college experience (Table 17). There were more full time students $(n=142)$ compared to part time students $(n=26)$. 
Table 17

Student Service Members' and Student Veterans Higher Education Trajectories

\begin{tabular}{lll}
\hline \multicolumn{1}{c}{ Higher Education Trajectory } & Frequency & \% \\
\hline Transfer Students & 88 & 51 \\
Completed some college courses in the military & 76 & 44 \\
Enrolled in college prior to military enlistment & 67 & 39 \\
Started as freshmen in college & 26 & 15 \\
Currently taking college courses during active-duty & 8 & 5 \\
\hline
\end{tabular}

Student service members' and student veterans' $(N=170)$ academic class status indicated that $31 \%$ were Juniors $(n=52), 29 \%$ were Seniors $(n=50), 14 \%$ Sophomores $(n=23), 4 \%$ Freshmen $(n=7), 15 \%$ Graduate Students in master's programs $(n=26), 4 \%$ Graduate Students in doctoral programs $(n=7)$ (Figure 4).

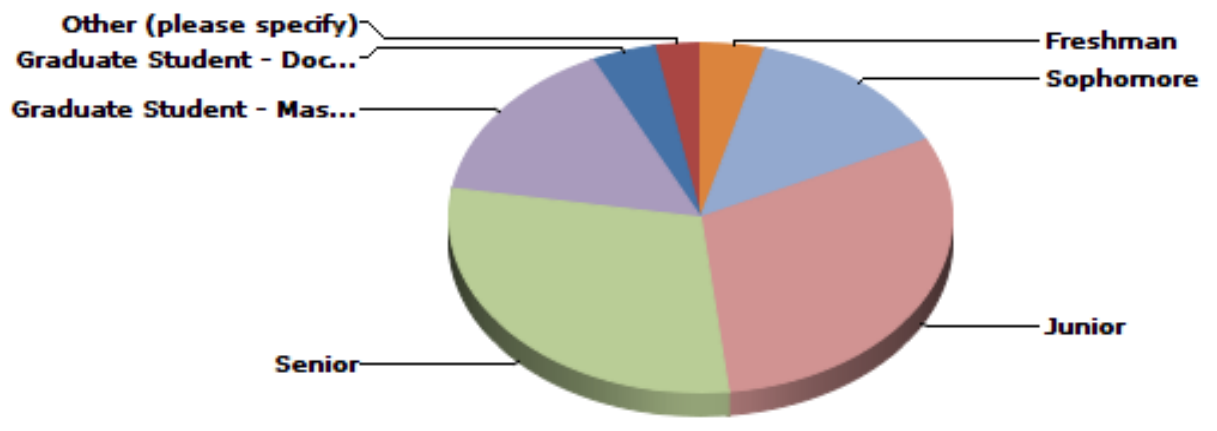

Figure 4. Students' Academic Class Status

The majority of service members and veterans $(N=155)$ were eligible for military education benefits in college with 79\% using Chapter 33 Post-911 GI Bill Active Duty funds. Not as many students used Chapter 30 Montgomery GI Bill Active Duty (26\%), 
Chapter 31 Vocational Rehabilitation and Employment (18\%), Chapter 1606 Montgomery GI Bill Selected Reserve (7\%), and Chapter 1607 Reserve Educational Assistance Program (REAP) (1\%). In addition to the U.S. Armed Forces' Tuition Assistance students indicated they sought out alternative funding sources to complete their education (5\%) (Figure 5).

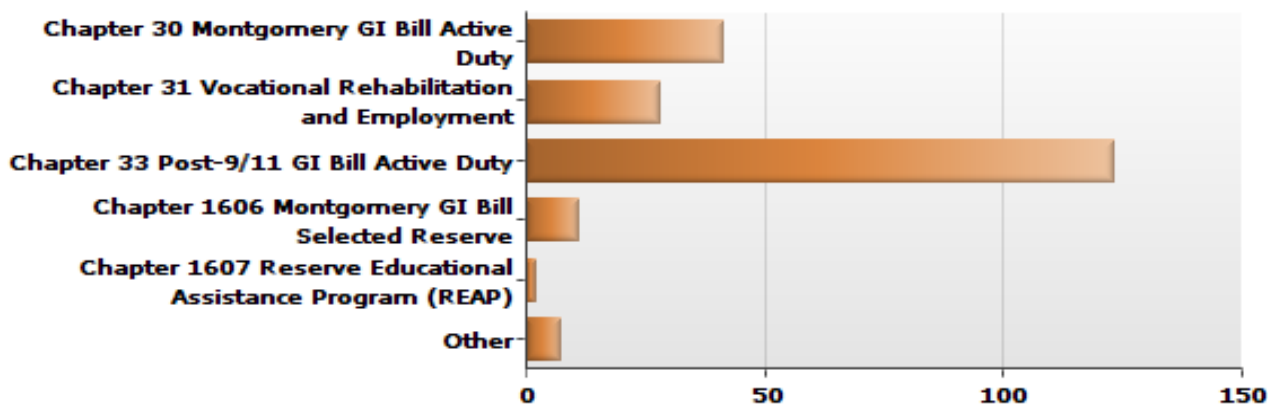

Figure 5. Education Benefits Used by Service Members and Veterans in College

The Classroom was the most popular site for $68 \%$ of student service members and veterans $(n=116)$ to complete coursework. Hybrid delivery of courses was selected by $31 \%$ of students ( $n=52$ ) out of 170 total respondents. Online services (19\%) was used exclusively by some $(n=32)$ for their academic work. Three students found (2\%) Virtual courses more to their liking and only one person (1\%) opted for Webinar access (Figure 6).

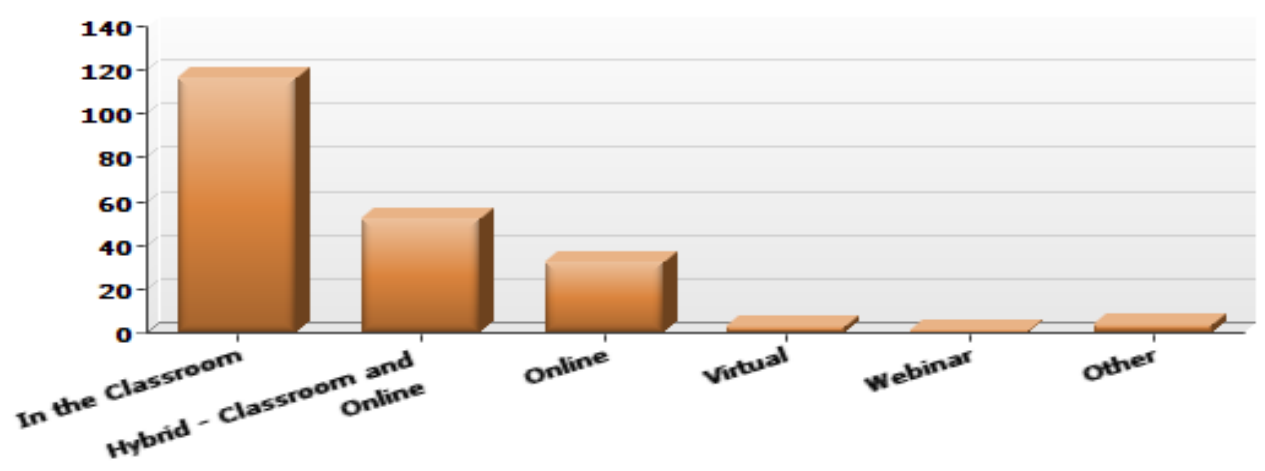

Figure 6. Delivery of Service Members' and Veterans' Coursework 
In transition the majority of student service members and student veterans indicated they attended a military friendly school with an accessible learning environment, the admission process was easy and they received timely process of their G.I. Bill education funds. The majority of students indicated they were prepared for college and have adjusted to student life. They mainly wanted to blend in on campus. Some students needed to upgrade their skills and learning although many perceived they were able to keep up with coursework. Many reported they did not participate in campus activities due to academic and personal commitments.

A number of students reported their first semester in college was challenging and others did not similar to their perceptions of relating to younger, civilian peers at first. For the most part they indicated faculty were respectful and considerate; however, administrators, staff members, and faculty should receive special training in supporting military members and veterans (Table 18). 
Table 18

\section{Military Friendly School Transition}

Likert Scale Values $>$ Strongly Disagree Disagree Neither Agree nor Disagree Agree Strongly Agree Frequency

This school has accessible and comfortable classroom learning environments. $(N=170)$

29

19

85

55

Admission to this school was an easy process. $(N=174)$

$\begin{array}{lllll}5 & 11 & 21 & 72 & 65\end{array}$

I experienced timely processing of my G.I. Bill paperwork and funds. $(N=171)$

$\begin{array}{lllll}4 & 14 & 28 & 52 & 73\end{array}$

My professors and instructors are respectful and considerate of students with military experience during lectures and class discussions. $(N=172)$

$\begin{array}{lllll}5 & 9 & 32 & 66 & 60\end{array}$

The administrators, staff members, and faculty should receive special training in supporting military members and veterans on this campus. $(N=173)$

$\begin{array}{ccccc}6 & 27 & 63 & 40 & 37 \\ \text { I was prepared for college. }(N=171) & 5 & 14 & 19 & 82\end{array}$

I experienced some difficulty relating to civilian students at first. $(N=173)$

$\begin{array}{lllll}36 & 32 & 20 & 49 & 36\end{array}$

I experienced difficulty taking quizzes, tests, and final exams. $(N=173)$

$\begin{array}{llrll}50 & 47 & 24 & 30 & 22\end{array}$

My first semester as a college student was challenging. $(N=173)$

$\begin{array}{lllll}28 & 37 & 28 & 44 & 34\end{array}$

I needed to upgrade my writing skills and knowledge of some basic education courses. $(N=170)$

4

48

20

33

28

I have identified a knowledgeable person on campus to serve as my mentor. $(N=172)$
35
42
49
27
19

I have responsibilities in addition to college courses and don't have time to participate in many campus activities. $(N=175)$

15

25

47

80

Veterans only classes have helped me to adjust to college. $(N=167)$

$32 \quad 21$

102

6

6

I just want to blend in with other students. $(N=171)$

$7 \quad 9$

57

52

46

I have not adjusted to college. $(N=172)$

83

53

18

15

3

Only $50 \%$ of students $(n=79)$ self-identified as service members/veterans collectively to

faculty, other military/veteran students, and civilian students; although 51\% disclosed this 
information to faculty on an one-to-one basis $(n=97)$ including $49 \%$ to their military/veteran peer group (Table 19).

Table 19

Self-Identification as a Military Member or Veteran on Campus

\begin{tabular}{lcc}
\hline Self-Identification To... & $\boldsymbol{n}$ & $\mathbf{\%}$ \\
\hline Faculty & 97 & 51 \\
Military Members and Veterans & 93 & 49 \\
Civilian Students & 91 & 48 \\
All of the Above & 79 & 42 \\
Administrators & 55 & 29 \\
Staff members & 50 & 26 \\
Identify only as a Student & 17 & 9 \\
Don't identify to anyone on campus & 14 & 7 \\
Other & 8 & 4 \\
\hline
\end{tabular}

Some $(n=17)$ preferred being identified as only a college student while $7 \%$ of students chose not to divulge their military/veteran status at all. Respondents

$(n=8)$ that selected $\underline{\text { Others }}$ made the decision to self-identify as military members/veterans "When it's relevant. Not just to inform them" and under these circumstances:

○ ...veteran loan documents as required

○ ...paperwork or to explain absences

○ ...use of Tuition Assistance, service-connected injury, prior job experience

○ ...come up in classes and other discussions

Success. Success in higher education was defined by the researcher as the continual focus on the completion of coursework to attain a degree despite challenges, difficulties or problems. Student service members and student veterans were mainly indecisive $(n=80)$ that pursuit of their education goals were made easier due to their enrollment at military friendly schools.

A smaller number of respondents $(n=31)$ did not agree their goal achievements were 
eased at military friendly universities/colleges, although over twice that many students $(n=64)$ perceived their progress were. Most $(n=155)$ reported they were happy with their progress toward degree attainment unlike eleven students that reported they were not and ten others that indicated they were uncertain at the time (Figure 7).

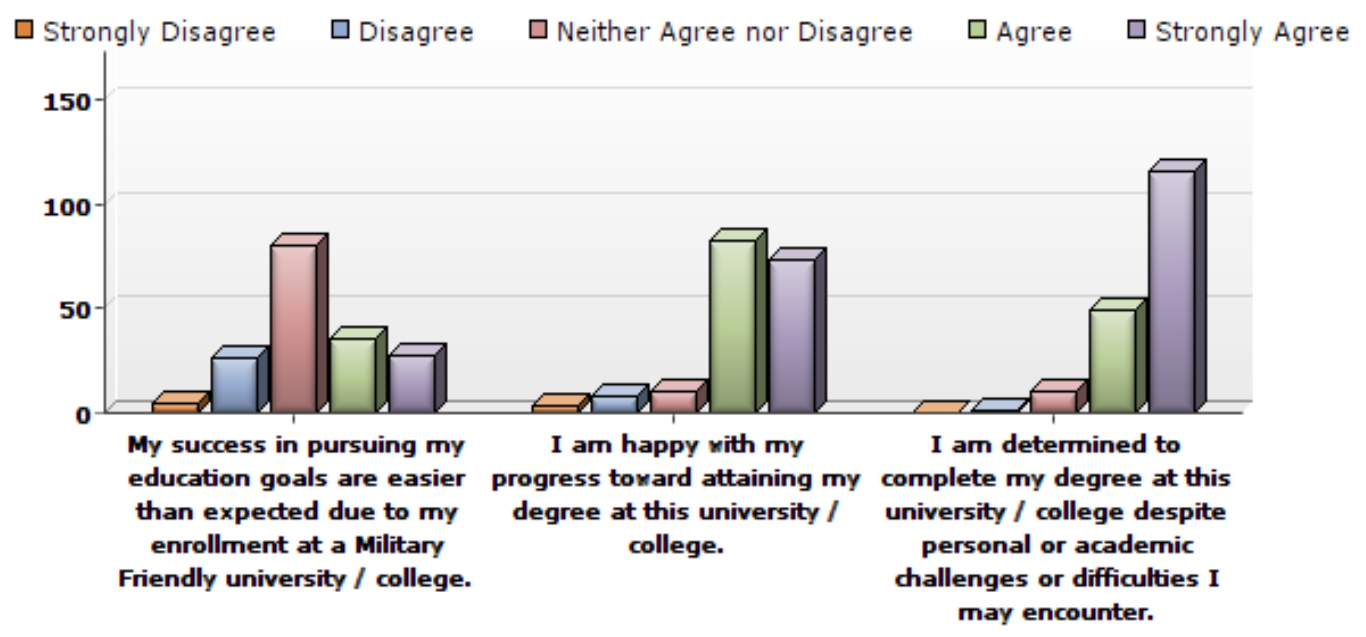

Figure 7. Students' Perception of Military Friendly Schools' Influence on Education Goal Achievement

Student success indicators were linked to respondents $(n=66)$ who participated in scholarly activities and sought out opportunities to advance their development during student life. The highest rated were: Student Support Services (38\%), Professional Development Seminar (35\%) and the Honors Program (29\%). A small percentage of service members and student veterans attended research (11\%) and academic (24\%) conferences and diversified their learning experiences outside of the U.S. in Study Abroad opportunities (11\%). They reported very little participation in federally-funded TRIO Programs such as Veterans Upward Bound (5\%) and the McNair Scholars Program (3\%) (Figure 8). 


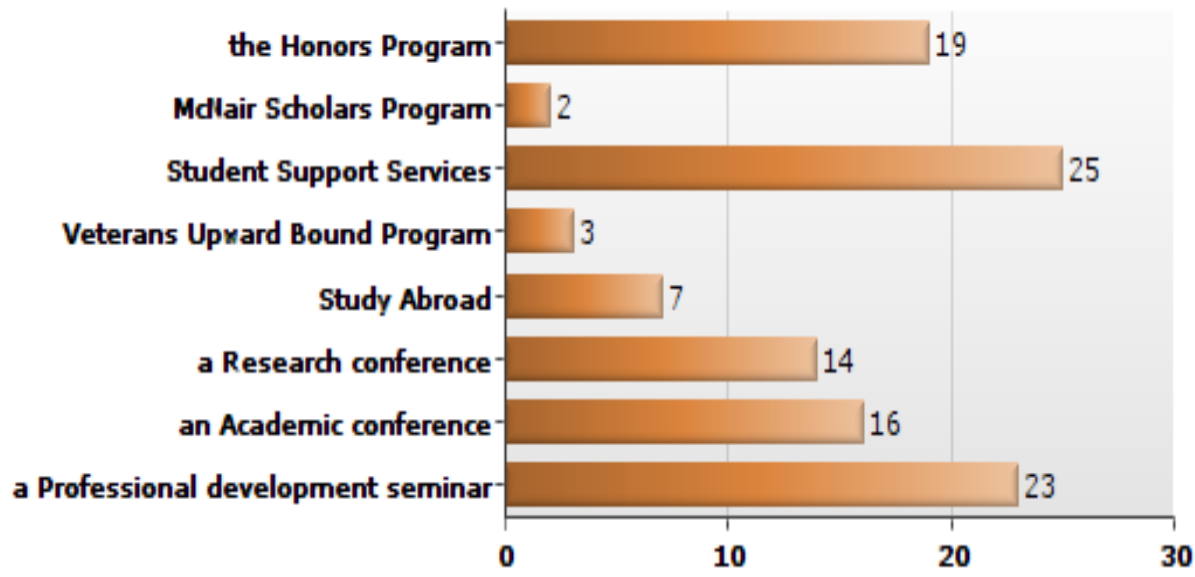

Figure 8. Scholarly Activities

Student service members and student veterans $(N=170)$ reported their GPA as: 4.0 $(18 \%), 3.5(33 \%), 3.0(23 \%), 2.5(7 \%), 2.0(1 \%), 1.5(1 \%)$. For the most part the range of GPA students listed in Others was high (Appendix D).

For the most part student service members and student veterans adapted to the rigors of academe and report positive learning behaviors. Many knew what their professors expected of them academically $(n=154)$ the requirements to graduate $(n=146)$, adjusted to the academic rigor of college $(n=143)$, and ask for help when needed $(n=134)$. Their extra-curricular involvement outside of the classroom showed minimal involvement in campus activities, schoolsponsored sports events and academic lectures (Figure 9). 


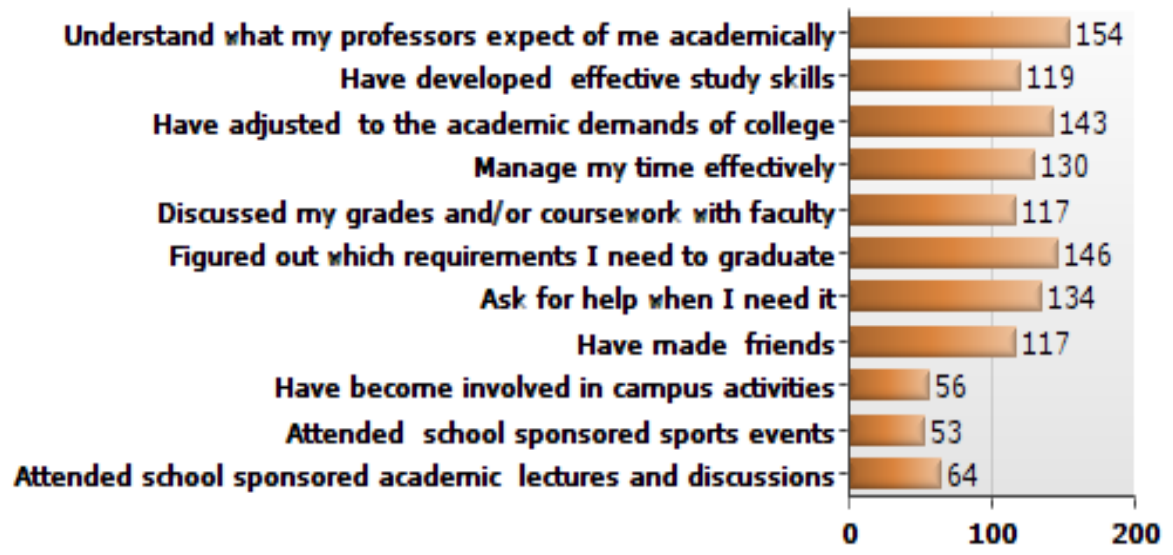

Figure 9. Students' Positive Learning Behaviors

Over $50 \%$ of students $(N=166)$ excelled academically and qualified for the Dean's List. In order to fully meet their education objectives many $(n=75)$ have applied for external sources of funding such as grants, scholarships and fellowships. They $(n=52)$ reported being members of a student group on campus and invested time $(n=43)$ in a Service Learning Project / Community Service or served as a volunteer. Attendance at Student Veterans Chapter meetings were low $(n=31)$ and few $(n=11)$ served in Student Government, as a tutor or mentor (Figure 10). 


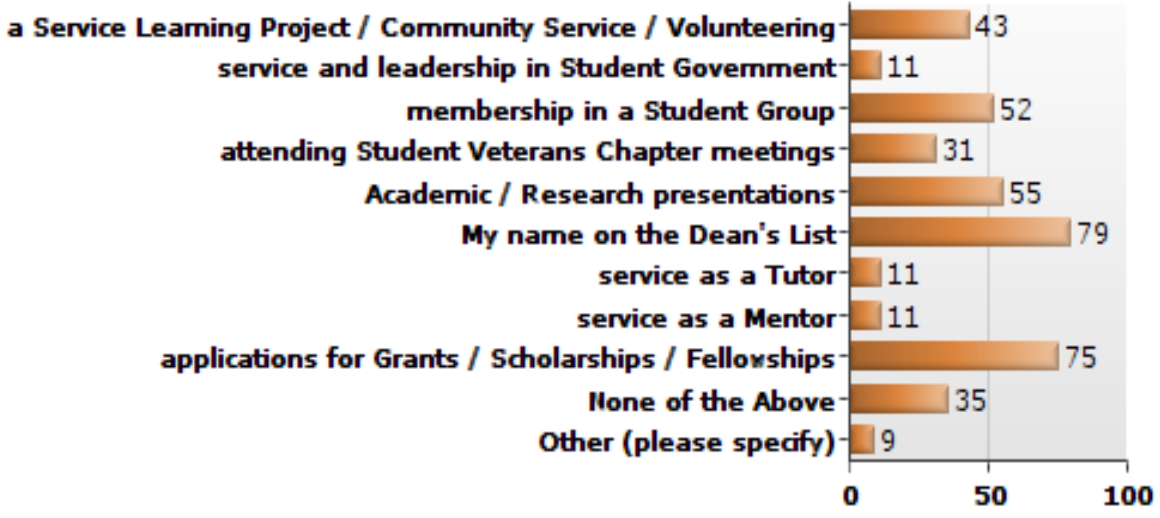

Figure 10. Student Life Activities

Student service members and student veterans $(N=168)$ listed their major or plan of study (Appendix E). There were a total of 152 respondents registered in fall courses in 2013. Most students $(n=52)$ enrolled in 15 credit hours. The highest number of hours taken in the semester was 21 by one individual. In the 2014 spring semester, the total number of respondents increased $(N=168)$ in every credit hour category compared to the previous semester except one. The difference was in the drop of students taking 15 hours (Figure 11).

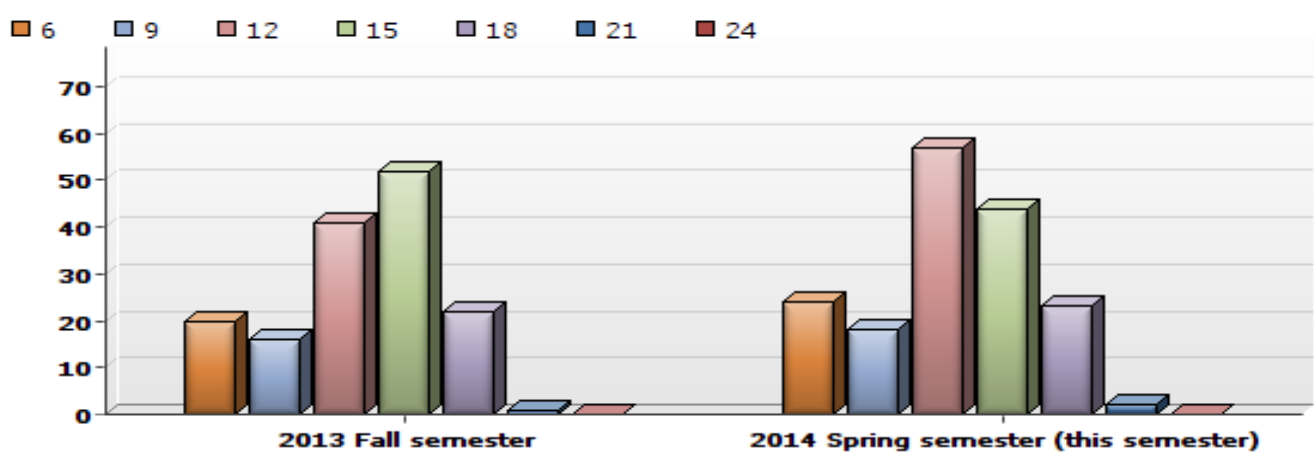

Figure 11. Number of Credit Hours Taken by Students in Fall 2013 and Spring 2014 
Most students accrued 28\% of the 90 hours or more credit hours required for graduation. Others included: $24 \%$ with $60-89$ hours, $21 \%$ with $25-59$, and $14 \%$ with $0-24$. Fifteen percent of respondents $(N=169)$ expected to graduate in the spring 2014 semester (Figure 12).

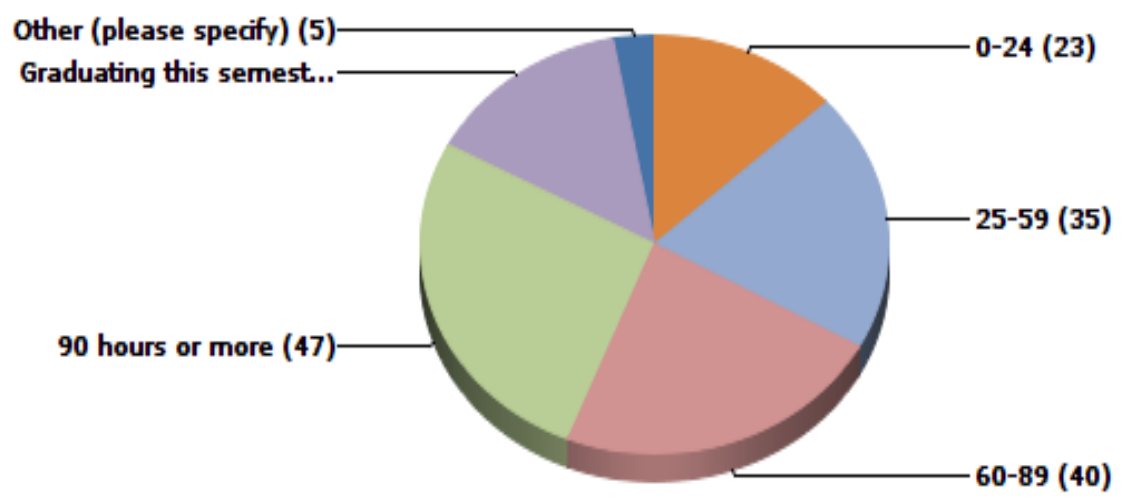

Figure 12. Number of Credit Hours Accrued Toward Graduation

Thirty-three percent of respondents $(N=169)$ attended all their classes during the semester. Some (30\%) missed 1-2 classes, 22\% missed 3-4 and 11\% missed 5-6. Only 2\% dropped a course. The Other $5 \%$ indicated they were online students. One person reported missed classes were due to three weeks of National Guard training (Figure 13). 


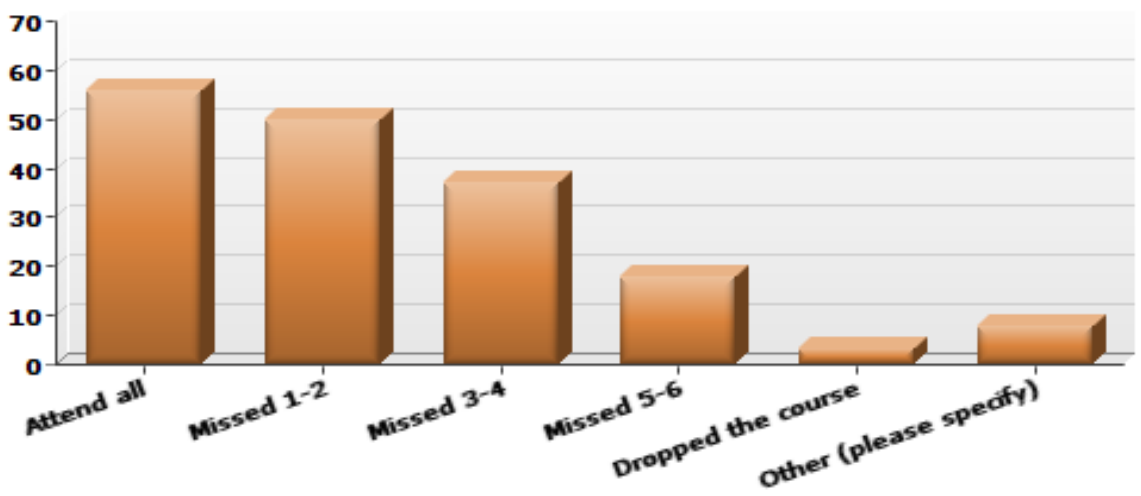

Figure 13. Number of Classes Missed In the Semester

The majority $(81 \%)$ of respondents $(N=166)$ indicated they would persist with coursework at the same school during the 2014, fall semester. Some students $(10 \%)$ planned to be employed and not take college classes, other students (7\%) expected to pursue their academic goals at another university or college, and 1\% would be on deployment overseas for the military (Figure 14). Students $(n=17)$ had in mind military training, internship, graduate school and student teaching in $\underline{\text { Other. }}$ 


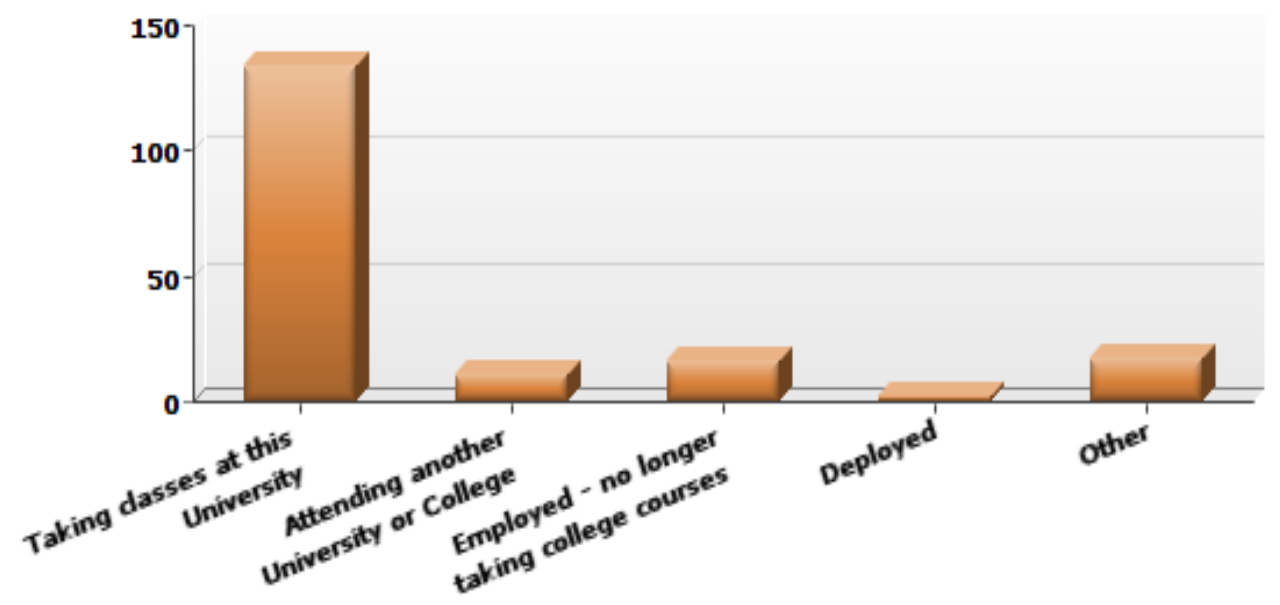

Figure 14. Students' Academic Plans for Fall Semester 2014

The majority of the respondents $(N=165)$ indicated the semester and year they planned to graduate. The dates mainly ranged from 2014 to 2017 with two people projecting graduations in 2018. One person remained uncertain.

Students $(N=164)$ indicated their career objectives after attaining their college degrees (Appendix E). Two people remained undecided about their professional outlook. Many respondents $(78 \%)$ planned to enter the civilian workforce $(n=132)$ following graduation, $12 \%$ wanted careers in the U.S. Armed Forces $(n=21)$, and 14\% were undecided $(n=23)$.

Not all of the respondents $(N=142)$ alluded to the special circumstances that would place them at risk of failing to complete their college education and not graduate (Appendix F). There were just as many student service members and student veterans that emphasized they would not fail or even consider the possibility at all. Some had successfully completed their programs of study and soon have a degree conferred by their university or college at the end of the semester in 2014. 


\section{RQ2-A: What are student service members' and student veterans' perceptions of camaraderie among military peers at military friendly campuses?}

Fourteen percent of military and veteran peers on campus report the same number of interactions among their group whether it is daily, once a week, or 2-3 times a month. About $10 \%$ indicated they engaged more frequently with each other about 2-3 times a week compared to the $6 \%$ of students that do so once a month or less than once a month (19\%). A larger number of military and veteran peers (26\%) did not interact with each other on campus (Figure 15).

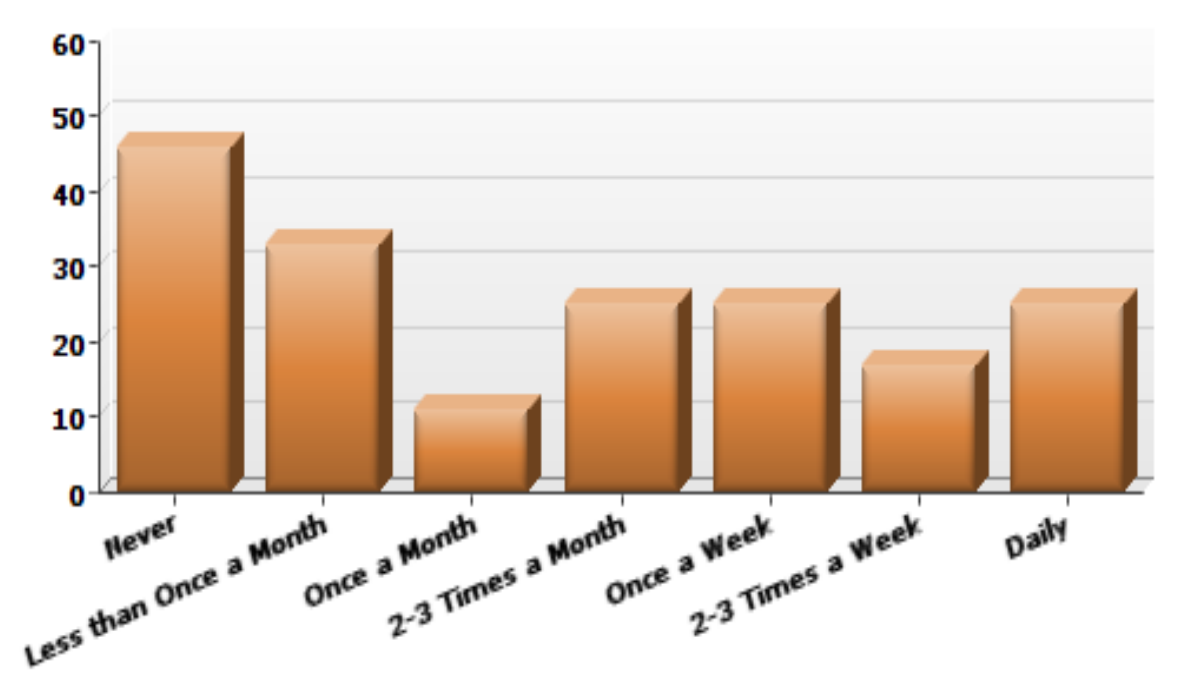

Figure 15. Interactions Among Military and Veteran Peers on Campus

Respondents $(N=83)$ bonded in the following ways: they socialized off campus $(n=46)$ shared a meal $(n=45)$, discussed personal feelings/problems $(n=37)$ and studied together $(n=35)$. Not as many attended school-sponsored sports events and campus activities together $(n=19)$ (Figure 16). 


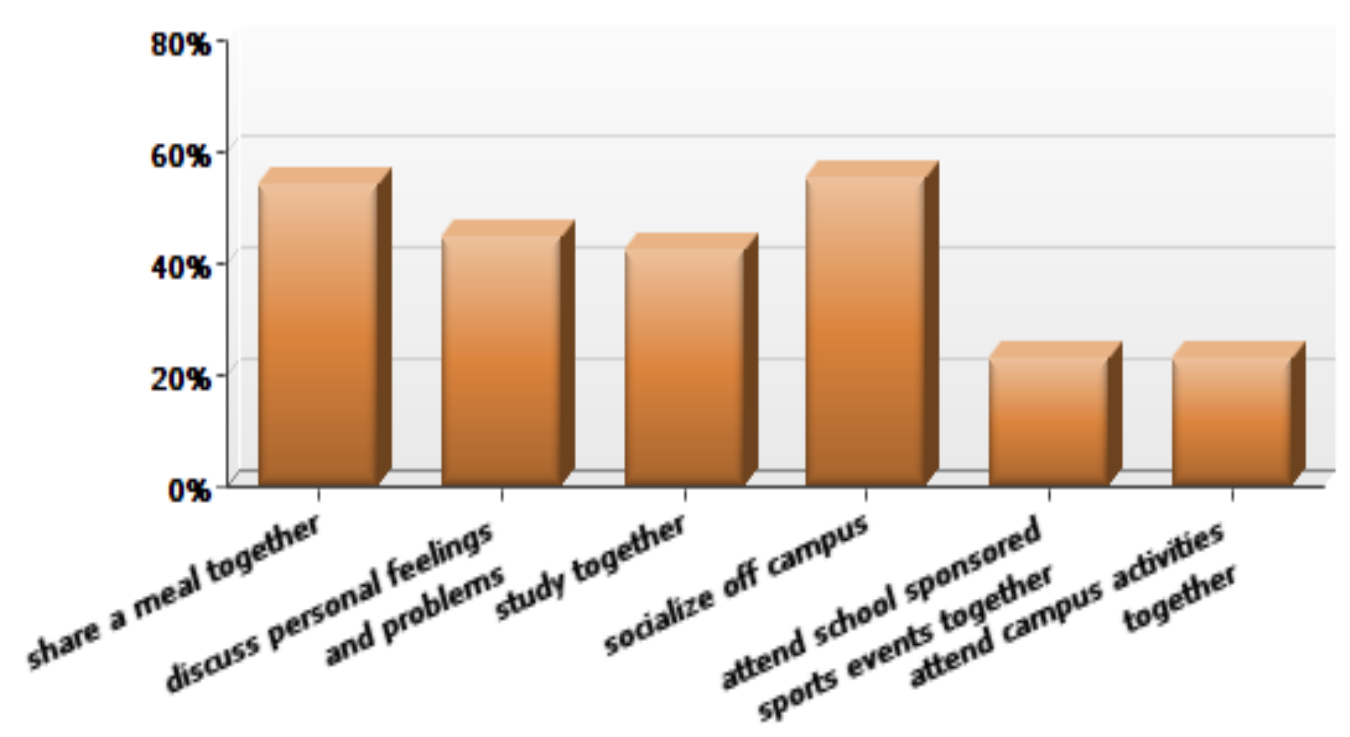

Figure 16. Bonding Among Student Service Members / Student Veteran Peers

Giving advice or information to each other was the primary support found among military and veteran peers $(N=138)$ with emotional closeness being the least (Table 20). Twenty-two percent indicated they experienced all support components.

Table 20

Support Among Military And Veteran Peers

\begin{tabular}{rcc}
\hline Support & $\boldsymbol{n}$ & $\mathbf{\%}$ \\
\hline Give advice or information to each other. & 79 & 57 \\
Have recognition of each other's competence. & 58 & 42 \\
Provide assistance to group members if needed. & 55 & 40 \\
Have a sense of belonging to a group of friends. & 47 & 34 \\
Have the assurance that members in their group can be counted on in times of stress. & 44 & 32 \\
All of the Above & 38 & 28 \\
Share an emotional closeness. & 31 & 22 \\
Other & 22 & 16 \\
\hline
\end{tabular}

Students were asked to describe to a civilian what camaraderie was as it related to military members and veterans on campus. A definition for camaraderie was disclosed and found 
applicable to this subpopulation in higher education from respondents' $(N=145)$ comments (Appendix H). The researcher constructed a collective perspective of camaraderie from students' answers as indicated:

As veterans and military members, we have each other's backs. We support each other, encourage and inspire each other. There is nothing like the feeling of knowing that you don't have to defend your actions, thoughts or beliefs. It's the freedom to be yourself and let down your guard and put away your mask for a moment and vent to someone who you know has shared the same rough times and sacrifices or have gone through similar training/experiences and by having that in common you bond. This bond is stronger due to the nature of what a person encounters in the military. The bond is so strong they get your way of thinking and become a part of your family. A family that is not related in blood or by titles but a family that you would be willing to defend with all your might in times of need. It forces you to look past the things about people that drive you crazy. You never had to have met another military person to care about them, especially if they were in the same branch. There is an instant connection when you meet another military member/veteran for the first time.

\section{RQ2-B: What are student service members' and student veterans' academic success and transition from the Armed Forces to higher education in relation to their perceptions of camaraderie among military peers?}

Support among military members and veterans $(N=135)$ was indicated in a number of ways: $40 \%$ indicated they provided encouragement $(n=54), 33 \%$ help $(n=45), 30 \%$ guidance $(n=41), 16 \%$ emotional support $(n=22)$ and $51 \%$ reported all of the above $(n=70)$. In Other 
respondents were not aware of or witnessed support among military peers especially those enrolled in online courses (Figure 17).

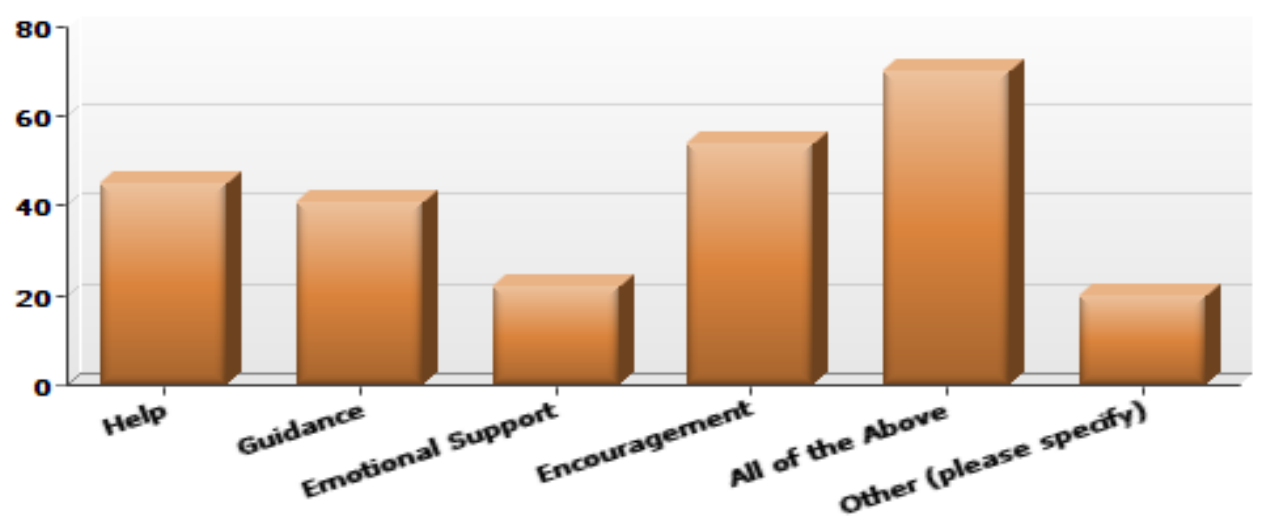

Figure 17. Supportive Behaviors Among Military and Veteran Peers

Forty-nine percent of military and veteran peers $(N=110)$ reported they assisted other group members thinking of dropping out of college $(n=54)$. A smaller number of students provided assistance to those $(n=18)$ showing risky behaviors and having health issues $(n=16)$. Forty-five percent indicated in the Other $(n=49)$ category some of the issues their peers contended with and needed help such as: academic problems, difficulty with the curriculum, not getting good advice from academic advisors, problems with the administration, study together, stress management, sobriety, family problems, and wanting to work out. Online students did not indicate assistance provided to peers, nineteen people reported 'none,' and seven 'not applicable' (Figure 18). 


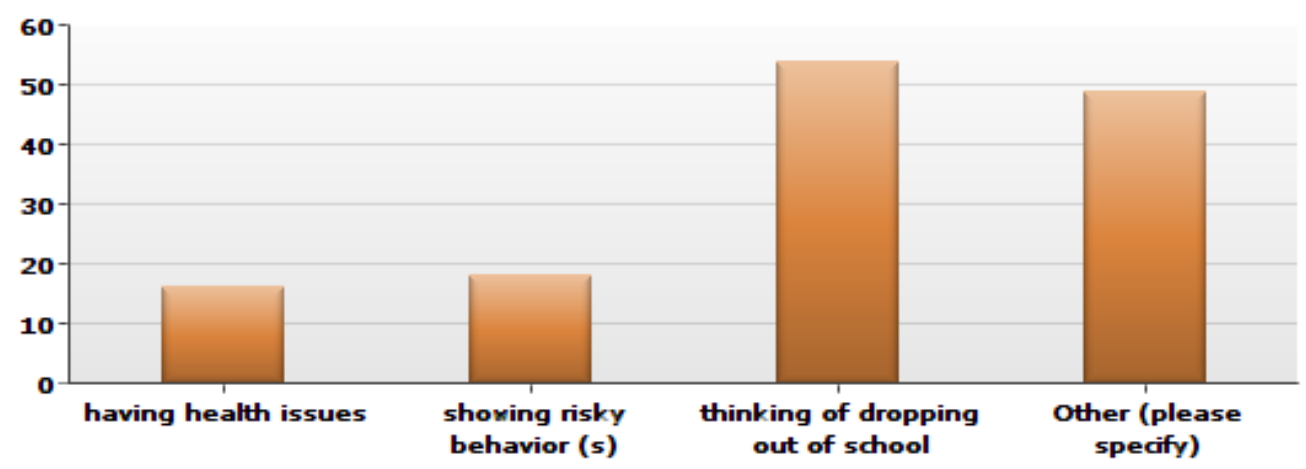

Figure 18. Assistance Among Military / Veteran Peers

The relationship shared among military members and veterans on campus indicated some students shared a close bond on campus and about the same number reported they didn't. Some agreed they had a military and veteran peer support network on campus with others disagreeing on this perspective. More students perceived the camaraderie they shared with military/veteran peers was not relevant to their student success compared to a small group that did.

Adjusting to college due to camaraderie was about even with students that perceived it was and those that did not attribute it to their transitions. More students perceived military/veteran peers have not helped them to stay focused on their academic goals although a few agreed they were helpful in this regard. Some students perceived military/veterans peers have encouraged them to graduate compared to a small number that disagreed (Table 21). 
Table 21

Military and Veteran Peer Relationship on Campus

Likert Scale Values $>$ Strongly Disagree Disagree Neither Agree nor Disagree Agree Strongly Agree Frequency

I share a close bond with military members and veterans on campus $(N=176)$

$\begin{array}{llll}29 & 30 & 55 & 39\end{array}$

I have a peer support network among military members and veterans on campus $(N=176)$

$\begin{array}{llll}28 & 38 & 53 & 42\end{array}$

The camaraderie I share with other military members and veterans on campus is relevant to my success as a student $(N=179)$

$\begin{array}{llll}30 & 38 & 64 & 27\end{array}$

My adjustment from the military to college has been made easier due to the camaraderie I share with other military members and veterans on campus $(N=176)$
31
35
66
30
14

Other military members and veterans on campus have helped me to stay focus on my academic goals $(N=176)$

$\begin{array}{llll}30 & 39 & 63 & 30\end{array}$

Other military members and veterans on campus have encouraged me to graduate $(N=176)$

$\begin{array}{lllll}22 & 28 & 67 & 37 & 22\end{array}$

Some student service members and student veterans shared additional information about their experiences at a military friendly school (Appendix I).

\section{Summary}

This chapter provided insight of student service members' and student veterans' perceptions of transition at military friendly schools, the climates, their success in academic pursuits and the influences of camaraderie on these conditions at seven universities and colleges in the United States. A focus group and online survey indicated the majority of students have 
adjusted to the rigors of coursework, excelled for the most part, and were focused on successful attainment of their degrees. Very few remained uncertain about their academic and professional futures. Many perceived their schools were military friendly.

Although institutional support was visible to students and in some instances emphasized strongly in the services and resources available to the military student community at some schools, others fell short and did not meet these criteria: priority registration, credit for military training and courses, in-state tuition, veterans lounge, competent and knowledgeable academic advisors, and flexibility of deadlines /coursework for military members on training or deployment.

The phenomenon of camaraderie was evident among focus group members relative to their persistence, academic, social, and personal wellbeing on campus. It created a bond akin to a family according to students. Survey respondents differed in their perceptions of camaraderie among military and veteran peers. Its presence mainly alleviated student isolation for those enrolled in courses on campus. The degree of influence of this support system on student success has received mixed review from respondents. Many agreed that it was a source of encouragement and help when needed for those with military experience.

The next Chapter Five provides a comprehensive reevaluation of the research in terms of new information aligned with that of past studies. It presents suggestions for best practices regarding service members and veterans in higher education and extends a future outlook for all stakeholders that have the best interest of this subpopulation in their strategic plans. 


\section{CHAPTER FIVE}

\section{DISCUSSION}

This chapter summarizes the information drawn from the data in Chapter Four. It details major conclusions found including surprising outcomes. The discussion leads to implications for practice in the field and proposals to create further understanding of the nature of transition in college by future students with military experience.

In 2009, President Obama announced a national commitment to increase the number of college degree holders in the United States (Advisory Committee on Student Financial Assistance [ACSFA], 2012). The commitment to achieve this goal was aligned with the legacy of the GI Bill, which has historically paved a direct route to college for service members since post World War II. Since then the new provisions of the Post-9/11 GI Bill in contemporary times has funded a new generation of student service members and student veterans in pursuit of their higher education goals (Kim \& Cole, 2013; Murphy, 2011).

The military education benefit used the most in 2011 , by over $50 \%$ of 920,000 students with military experience was the GI Bill (Altus, 2013, p. 19). This was one of the reasons that a report released by the Department of Veterans Affairs was disturbing to everyone having a vested interest in these students' success. It pointed out that $33 \%$ of service personnel and veterans were among the thirty-seven million adults aged 25-64 in the U.S. that attended college and did not attain degrees (Northrup, 2013, p. 69).

Over the years since the events of September 9, 2001, the existence of advertised military friendly colleges and universities increased substantially along with incoming service members and veterans. Some institutions in higher education activated extensive effort into developing transition programs with supportive campus climates that accommodated the 
needs, interests, and persistence of students who have served in the military.

Service members' and veterans' personal commitment to attain a degree in campus cultures that purport to be student friendly and military friendly were immersed in an environment perceived to decrease the likelihood of academic, social and personal learning barriers (Advisory Committee on Student Financial Assistance [ACSFA], 2012; Knefelkamp, Widick, \& Parker, 1978).

These institutions were supposedly veteran-centric with services, resources, and curriculum that exhibited a strong network of support in addition to the offerings of Academic Services and Student Services available to the general student population. The use of GI Bill education benefits for tuition assistance at these colleges and universities were sanctioned by the U.S. Department of Veterans Affairs' (VA) and Department of Defense (DOD) (Howell, 2012).

The increase of fraudulent practices in recent years by some institutions resulted in a large number of students not receiving the education they paid for, or not graduating from schools with accreditation. The Armed Forces, Education Services Specialists, and military advocate organizations such as: Student Veterans of America [SVA], Servicemembers Opportunity Colleges [SOC], and the American Council on Education [ACE] ) advised service personnel and veterans to be cautious in the use of their military education benefits (Eagle \& Bailey, 2013). They needed to be informed consumers when seeking information especially of schools that emphasized the military or veteran friendly brands.

The lack of empirical research on the military friendly school phenomenon in higher education became important to consider when the academic welfare of a unique student subpopulation such as military members and veterans was at stake. Some general questions 
came to mind such as: Exactly how military friendly were these specific colleges and universities? Did institutional support of the special needs, interests, and success of the military student community surpass those without the attached military friendly designation? Did students thrive and progress in this environment? Exploring these preliminary thoughts became focused in this research followed by one last general question based on students' perception of transition, What will the report card show about military friendly schools?

The purpose of this study was to explore the degree to which colleges and universities claiming to be military friendly campus climates, supported student service members,' and student veterans' transition through their policies, practices, and resources. Also of interest, was the exploration of the phenomenon of camaraderie found among student service members and student veterans that evoked feelings of success in higher education within the military friendly parameter.

Four research questions were addressed in this research:

* What are student service members' and student veterans' perceptions of their military friendly campus climates?

What are student service members' and student veterans' academic success and transition from the Armed Forces to higher education in relation to their perceptions of military friendly campus climates?

* What are student service members' and student veterans' perceptions of camaraderie among military peers at military friendly campuses?

What are student service members' and student veterans' academic success and transition from the Armed Forces to higher education in relation to their perceptions of camaraderie among military peers? 
The collective perceptions of students having past or present military service were the best sources to judge their performance in academic coursework and assess the military friendly designated schools they selected to complete degrees. Each institution's Office of Military/Veterans Affairs administrator was contacted by phone call or email to assess their interest in having their military student community take part in the study. The willingness of each administrator to forward the researcher's recruitment email and research information to students was crucial to the successful continuity of the research.

A mixed methods, sequential exploratory design was used to elicit qualitative and quantitative information which was conducted in two phases. Priority was given to the qualitative data collection in Phase I in which a focus group was used. Participants $(n=7)$ were recruited at Concord University in West Virginia, and purposely selected due to their availability on a specific date and time.

This was the foundation of the research in which group members shared their perceptions about transitioning in a military friendly school that was markedly supportive of students that served in the military. The meeting was held in the veterans lounge on campus. Their narratives informed the development of the questionnaire Where Failure Is Not The Option Military Friendly College/University Survey (WFINTO SURVEY) delivered to students in a web-based survey in Phase II.

The survey was comprised from focus group data and information gleaned from past studies on student service members and student veterans in higher education (Hadley, Trechter, \& Parks, 2011; Kim \& Cole, 2013; Lang \& Powers, 2011; McBain, Kim, Cook, \& Snead, 2012; Sternberg, Wadsworth, Vaughn, \& Carlson, 2009; UWRF Veterans Survey Report, 2011; Weiss, 1973, 1974; Zinger \& Cohen, 2010). Five student veteran alumni pre-tested the instrument for 
sensitivity of language, type of research questions posed, relevance to the research questions, number of questions, and survey completion time. Based on their feedback the original draft was revised.

A second evaluation of the instrument was conducted by two other veterans. They found the modified version of the survey to be sufficient for exploratory research purposes. Participant fatigue was an important consideration. The survey time was found to be 12-25 minutes which was dependent upon the respondent's attention allotted to each question.

The WFINTO survey consisted of a total 48 questions. Closed-ended and open-ended questions were used within the following categories: (1) Military Friendly School, (2) Transition, (3) Camaraderie, and (4) Demographic Information. Four questions acquired qualitative data. The section related to camaraderie was inspired by the six components of the Social Provisions Scale developed by Weiss $(1973,1974)$ and the modified version that Cutrona and Russell $(1987,1990)$ presented.

In Phase II, respondents $(n=170)$ were recruited from seven military friendly colleges and universities the researcher found on websites frequented by service members and veterans that listed schools having the military or veteran friendly brand. The sample was random as students interested in taking part in the research accessed the survey link forwarded by the Office of Military/Veterans Affairs administrator at each institution. Qualtrics software collected the quantitative data.

\section{Analysis}

Thirty-one pages of raw data from the focus group was transcribed verbatim twice. The researcher used two tape recorders during the discussion. Check coding determined reliability of the documents in which both transcribed scripts were compared and reviewed 
numerous times which provided verification and accuracy of participants' words (Kvale, 1996). Narrative text was organized according to the four research questions aligned with those listed in the Focus Group Question Guide. This was referenced with observational field notes and the researcher's preliminary assessment notes written during the focus group meeting. Initial open coding reduced and sorted the data into categories and subcategories drawing out themes and concepts (Riessman, 2008, p. 3).

Three themes emerged: (1) A military friendly climate is one that is presently beneficial for students and develops strategies of support in anticipation of their needs; (2) The quality of transition in a military friendly climate fosters students' success and persistence, prevailing over challenges; (3) Camaraderie is an adaption of the individual veteran's desired support and degree of reciprocal social interaction within the military community on campus.

Survey respondents were not required to answer all questions. This option resulted in varying degrees of sample size pertaining to some questions and consistent with the $86 \%$ overall number of respondents and the $14 \%$ dropout rate from 198 respondents that started the survey and 170 that completed it. Qualtrics software was used to analyze descriptive statistics the following variables:

Students' perceptions of campus climate

Students' perceptions of camaraderie

Student Success: GPA, graduation date, course completion, number of credit hours, attendance, time management, attending orientation, academic and professional development, student group membership, service learning, study abroad, school leadership, application for scholarships and fellowships, Dean's list, internship, 
Honors Program, McNair Scholars Program

* Transition: friends, extra-curricular activities, support services, asking for assistance, civilian peers and faculty, veterans courses, GI Bill benefits, enrollment in college

Questions measured with a Likert scale of 1-5 showed frequency of responses and percentages. Central tendency, variance and frequency were assessed for quantitative data derived from closed-ended questions (Salkind, 2008, p. 8). The qualitative information acquired from the open-ended questions were sorted into categories and evaluated for word frequency and phrases. Plausible definitions for military friendly and camaraderie were determined.

The two data sources were triangulated to increase the validity of the study. The strengths of qualitative and quantitative information served to counter-balance the other (Clark $\&$ Cresswell, 2008, p.108). In this way, qualitative descriptions had a complementary purpose and supplemented quantifiable information. The results were not reflective of the larger population of student service members and student veterans enrolled in college from MayJuly, 2014 in the U.S.

\section{Major Findings}

Military Friendly School/Climate. Three popular websites service members and veterans sought college information:

* 31\% U.S. News \& World Report, 24\% G.I. Jobs, 19\% Militaryschools.com

Primary factors of military members' and veterans' college selection: convenient location (65\%), affordable (31\%), always wanted to attend this school and military member / veteran recommended (17\%) 
$8 \%$ of military members and veterans select a school based on the Military Friendly brand/logo posted on the website

- designated as Military Friendly and endorsed by popular websites impact $24 \%$ of students' decisions to enroll in a school

* $81 \%$ of students perceive their college / university was military friendly

* 54\% of students indicate their education goals were expedited

* $68 \%$ of students perceive their school's support services for military and veteran students are satisfactory

- $67 \%$ of students indicated resources, services, and programs available to military and veteran students would help them to graduate

* $35 \%$ of students indicate they would not enroll in a school that was not military friendly

$46 \%$ of students indicate their professional goals are expedited

$79 \%$ of students used the G.I. Bill to achieve their college education

$43 \%$ of students perceive they were in a military inclusive campus culture

* A definition for military friendly school was developed from student service members' and student veterans' feedback

Several websites that are often used by military personnel and veterans to inform their decisions about colleges and universities are U.S. News \& World Report, G.I. Jobs, and Militaryschools.com. Selecting a school was often based on the location and cost of attendance according to respondents. Others' long-held desire to attend a particular institution and recommendations from other military members and veterans were part of the consideration process as well. This was in addition to the small number of potential college students who are 
easily swayed by endorsements found on popular websites. Very few service members and veterans are interested in whether the military friendly brand/logo was posted on a school's website and some may likely perceive it to be a gimmick of advertisement. However, the brand is symbolic of the institution's commitment to graduate this student subpopulation from the standpoint of its policies, initiatives, and practices (American Council on Education, 2013). It also has a structure of active support and outreach to the military student community with a transition program in place.

The majority of students perceive their school to be military friendly and their education and professional goals are on the fast track in this campus climate. The G.I. Bill is most often used as student service members' and student veterans' primary financial resource for tuition. Programming and related services was adequate for students' purposes and needs in which graduation was likely anticipated. It is for these reasons that some students indicate they would limit their college choices only to military friendly schools which they perceive was also a military inclusive campus culture.

Students' feedback (Appendix C) serve as the basis of definition in explaining the nature of the military friendly school phenomenon. It offers a campus climate that decreases the academic, social, and personal barriers that likely detract student service members' and student veterans' persistence of their goals in higher education (Advisory Committee on Student Financial Assistance [ACSFA], 2012; Knefelkamp, Widick, \& Parker, 1978)

The report Student Veterans/Service Members' Engagement in College and University Life and Education is from the results of the 2012 National Survey of Student Engagement. In comparison to civilian students, student service members and student veterans perceive support services on campus favor civilian peers. Many higher education institutions have implemented 
programs and services directed at the specific needs of military members and veterans since the Post-9/11 G.I. Bill was revised in 2010 by the legislature. Dependent on the priority of each institution those services currently available to the general student population may likely be considered sufficient for all students at the time. In a competitive market many schools conduct rigorous recruitment of service members because the G.I. Bill has become a lucrative "ATM machine" for higher education over the years.

Those that have military friendly policies must be cognizant of the gaps in their climates that create murmurs of dissatisfaction among a student group with over a $50 \%$ transfer inclination to other schools. The retention of student service members and student veterans require institutions to recognize these students "are in it for the education" and are a unique group of nontraditional learners. They need to be recognized for their own merit and value to the institutions they attend and to the larger society as those WWII service members that contributed substantially to America's economy following their own college graduations.

It appears many student service members and student veterans don't necessarily want to stand out in a crowd of students in college or have to fight another battle in the civilian sector for accommodations such as priority registration that some institutions readily provide to other student groups. The truly military friendly schools have an altruistic nature to their support and delivery of services for military and veteran students such as Concord University and San Diego State University to name a few.

They are able to easily check off the services in place without hesitation or likely argument from the Registrar's office which is an ongoing issue at the premiere land grant university in West Virginia. Military and veteran students have continually requested priority registration over the course of years. 
As in the focus group transfer students, many student service members and student veterans are probably not aware of the dedicated military friendly delivery of services and support at first compared to their experiences at other schools where they basically settled, or didn't push the issue, or thought that was the way colleges are. However, when they do make the connection at an institution that values this student population they come to the realization that the quality of transition is positively enhanced and clearly unexpected. Surprisingly, they find that "it's a good thing to have."

Transition. Service members differ in their experiences of transition and what they find meaningful to be involved in:

* $39 \%$ of students took some college courses prior to enlisting in the military

* $53 \%$ of service members participated in a Transition Assistance Program (TAP) class in the military

* $60 \%$ of service members did not seek college guidance and information from a Military Education Specialist

$24 \%$ service members and veterans register in college courses within two years of separation from military service

* $51 \%$ are transfer students

* $84 \%$ are full time students

* $31 \%$ are Juniors, $29 \%$ are Seniors, $14 \%$ are Sophomores, $4 \%$ are Freshmen

$76 \%$ of students have access to an Office of Military/Veterans Affairs at their campus

- 51\% of students indicate their school has a Veterans Lounge or One Stop Center

$79 \%$ of student service members and student veterans used Chapter 33 Post-911 GI Bill Active Duty education benefits 
* $68 \%$ of students attended classes on campus

* $78 \%$ of students perceive they were prepared for college

* $50 \%$ of students self-identified as service members/veterans to faculty, military/veteran peers, civilian students

Some past research on military students and veterans highlight the pros and cons of college life that impact their transition experiences from various angles of involvement and engagement with others often giving the impression that the challenges seem too numerous to contend with (Ackerman and DiRamio, 2009; Cate, Gerber, and Holmes, 2009; Cook and Kim, 2009; Rumann and Hamrick, 2010). The students in both Phases of the present study differ in this nature although unexpectedly candid in their feedback they maintained an outlook of resolution in creating awareness of existing gaps that mar transition programs at military friendly schools. As for the students, the climate alone can't be held accountable for any less than ideal perceptions of their immersive learning in higher education, as other factors exert their influences.

It is probable that reintegration into the civilian sector is experienced with less difficulty by over half of the respondents that were within 180 days of separating or retiring from military service by taking workshops in the Transition Assistance Program (TAP). Spearheaded by the U.S. Department of Labor each branch of the Armed Forces basically provides a three-day crash course held at various military installations in the country in professional development and offers information about employment, training, and G.I. Bill benefits. This introduction likely offset the "barriers to success" that service personnel sometimes unknowingly encounter in preparation for their future careers (U.S. Department of Labor, n.d.).

Those interested in higher education focused on ordering transcripts of courses and 
training undertaken in the military and submitting applications to colleges and universities. Prior to enlistment some service members enrolled in college level classes and did not complete their programs of study. They now had a second chance to remedy that situation and pursue their academic and professional interests (Murphy, 2011).

Military Education Services Specialists are exactly what their job title implies. They are positioned to assist service members make informed choices about colleges and universities that roll out the welcome mat to students with a history in the military. Very few service members took advantage of this resource which may have helped them gain some perspective about the complex process of G.I. Bill paperwork and funding (Hobbes, 2012), since a fairly large number used Chapter 33 Post-911 GI Bill Active Duty education benefits. As new beneficiaries of the original GI Bill's legacy they reflect the democratic mix of nationalities found in the United States today (Eckel \& King, 2006).

Past studies presented barriers, challenges, and sometimes harsh realities student service members and student veterans confronted in their transitions at two-year and four-year colleges and universities, public and private institutions, for-profit and non-profit schools located at rural and urban locations (Bissell, 2013; Capps, 2011; Carne, 2011; DiRamio, Ackerman, \& Mitchell, 2008; Doenges, 2011; Elliott, Gonzalez, \& Larsen, 2011).

Their 'truths' were remarkably unsettling in relation to the present study where transitions and military friendly schools overlap in which students' perceptions of higher education indicate they've adjusted to the climate and were better prepared for the college experience. In the past few short years many institutions have pumped up their support and related services to address the needs of current military and veteran students which may include all or some of the following considerations on campus: 
Office of Military and Veterans Affairs

Waive or relax application deadlines for deployed service members

- Waive application fees for service members and veterans

* Easy-to-use websites that address military and veteran students' frequently asked questions (FAQs) with point of contact listing

* Separate orientation session for incoming military members and veterans

* Counseling and therapy services for PTSD, TBI, Depression

* Career counseling

- Priority registration

* In-state tuition

* Knowledgeable and competent academic advisor

* Yellow Ribbon Program

College credit for military courses and training

Grants, scholarships, and fellowships

Mentoring by faculty with military experience

Buddy-system

* Veterans Lounge/One Stop Center

Many students have access to an Office of Military and Veterans Affairs on their campus although only half of the respondents enjoy the convenience of a One Stop Center or the privacy of a Veterans Lounge allocated for their use at their schools and many more report the timely process of G.I. Bill education benefits. Unfortunately, a large number of services need a good dose of institutional attention and fast response in the military friendly climates respondents are currently enrolled at. So far none of the schools have reached the fifty percentile mark in their 
delivery of services and new programming. In fact their status of friendliness is in jeopardy in regard to academic advising, mentoring, and Buddy-system.

These gaps in institutional non-committal or to put it plainly, 'dragging their feet' is somewhat reflective of the Soldier to Student II Survey 2012 national study of 690 colleges and universities in the U.S. conducted by McBain, Kim, Cook, \& Snead (2012). The data highlighted the inadequacies of schools in a three year time span from the first Soldier to Student Survey in which Transition Assistance had risen to $37 \%$ and Expedient Re-enrollment Process to $28 \%$. Granted it was some progress after all since each institution started at zero. Still, it is difficult to comprehend why Social Acculturation and Raising Faculty and Staff Sensitivity was stagnant, never moving past zero from 2009 to 2012. They were two areas these colleges and universities seemed to have missed or totally ignored.

In transition the majority of student service members and student veterans were undergraduate students with juniors outnumbering seniors attending classes on campus. A small group of respondents were finishing up their freshmen year. There were many more accepted into master's programs compared to those seeking doctorate degrees. A large number were full time students and some attended part time. Over half of all respondents transferred to their current schools.

The variation in time frame from military service to college indicate more military members and veterans delayed college for at least two years after separating from the Armed Forces. The frequent points of entry in higher education were 1-2 weeks, 3 months, and 1 year. The same number of respondents enrolled in a college or university across the three time frames. Those choosing 4-6 months waited briefly before making their appearance on campus which was aligned with active duty service members' decisions to begin coursework in this same time 
frame.

The quality of students' transitions was perceived as positive in terms of school admission, G.I. Bill benefits, classroom facilities and learning environment, respectful and considerate faculty, and their adjustment to college. Not all students determined their first college semester was challenging or an upgrade of skills and basic education review was needed. They were uncertain whether veterans only courses help ease trepidations of routines and demands in academia and finding a mentor was not an easy task for many.

However, respondents were divided in their perceptions relating to civilian students. The differences between the two peer groups were emphasized when some student service members and student veterans described traditional age civilian peers in research as "uncomfortable, immature, or self-centered" (Doenges, 2011; Green, 2012; Livingston, 2009; Murphy, 2011).

Students have the expectation that key personnel, staff, and faculty require some amount of training in order to adequately support service members and veterans on campus. They were fairly adamant that personal responsibilities and coursework limited their participation in many campus activities. Some joined student groups on campus although, their attendance at Student Veterans Chapter meetings were low. Most of all student service members and student veterans wanted to blend in with the mainstream student population yet only half of this subpopulation would self-identify their affiliation with the military to others.

Success. Persistence and retention of student service members and student veterans indicate their commitment to their academic goals to persevere and reach graduation for most:

$94 \%$ of students were determined to complete their degrees at their current school despite personal/ academic challenges or difficulties encountered

* $82 \%$ of students have adjusted to academic rigor 
* $58 \%$ have a father or mother who was a college graduate with a bachelor's degree

* $75 \%$ of student service members and student veterans don't have time to participate in many campus activities due to personal responsibilities /college coursework

* $77 \%$ of students ask for help when needed

* $67 \%$ of students indicate resources, services, and programs available to the military student community will help them to graduate

$89 \%$ of students were happy with their progress in college

$38 \%$ of students participate in Student Support Services

$35 \%$ of students participate in Professional Development Seminars

* $29 \%$ of students are in the Honors Program

students' top three GPA status: $18 \%$ (4.0), 33\% (3.5), 23\% (3.0)

$48 \%$ of students are on the Dean's List

$28 \%$ of students have $90+$ credit hours toward their degree

$33 \%$ of students attend all their classes during the semester

* $81 \%$ of students indicate they would complete coursework at the same school in fall semester 2014

* $78 \%$ plan to enter the civilian workforce after graduation

Student service members and veterans appear to have a strong commitment to attain their degrees once they begin along this path. The idea of failure is unlikely to happen according to students (Appendix G). Very few indicate a reason why this goal would not be within reach. They are confident they will persevere and overcome barriers and challenges whether academic or personal. One participant in the Zing and Cohen (2010) study whose access to higher education was supported by the GI Bill expressed his uncertainty about transitioning 
in college, "My biggest fear is the fear of failure....not being successful" (pp. 42-45).

Generally, it seems students were happy with their academic progress at military friendly schools. About half of this campus subpopulation reportedly has a parent who has graduated from college with a bachelor's degree therefore sharing in a legacy of college participation in their families. In comparison, there are military members and veterans who are first-generation college students whose mother or father did not attain the baccalaureate.

Federal TRIO Programs at many institutions across the country -such as the Veterans Upward Bound Program and the Ronald E. McNair Postbaccalaureate Achievement Program help to advance the education prospects of first-generation and underrepresented minorities and hone their learning skills. A mere $8 \%$ of student service members and student veterans were advantaged by TRIO services.

A large number of contemporary military students and veterans seem to thrive in college and adjust to the rigors of higher education, being receptive to the idea of asking for help when they need it. More than half perceive they have the resources, services, and programs structured specifically for student service members and student veterans available at their schools to help them graduate. They have applied themselves accordingly in a climate that places a high priority upon their success. In their best interest they've sought out development opportunities in Student Support Services, Professional Development Seminars, the Honors Program, and scholarly activities such as research and academic conferences.

From all appearances students are proactive learners (Astin, 1984; Evans, Forney, \& Guido-DiBrito, 1998) that draw from the various experiences that are a part of student life in college such as experiential learning Service Learning Project / Community service / volunteer and Study Abroad 11\%. Time spent on activities still left adequate time to concentrate on 
coursework as $74 \%$ reported they managed their time effectively. They were similar to participants in the Kim and Cook (2013) study in not wanting to work on assignments with students outside of the classroom compared to the higher number of civilian peers that do. "My best group projects have all had other service members in them, the only problems with individuals not applying an effort or completing their assigned part of the project has come from young civilian students.”

About half are on the Dean's list with high enough GPA's (Appendix D) that a good many among their group could matriculate to master's programs or set their sights on doctoral education if they so desired. Their persistence was aligned with the accruement of credit hours needed for graduation and responsible enough that many more attended all their classes during the semester compared to those that continually missed classes or the very few that dropped a course. It is unlikely attrition of these students would be high as many were juniors and seniors with others awaiting graduation in a week or two. The graduate students appear to be focused on their program of studies.

Student service members' and student veterans' majors (Appendix E) often represent their professional objectives (Appendix F) in the civilian sector. The leadership and knowledge they gained in the military is supplemented with the cross over skills, expertise, and credentials that immersive learning in college offers and employers seek (DeGroat and Crowley, 2013). A small number of individuals plan careers in the Armed Forces. In many ways, the tangible rewards of successful college involvement are subjective although human capital development impact productivity in individuals' chosen fields (Hershberg, 1996). 
Camaraderie. Simply put, camaraderie in higher education is peer support among student service members and student veterans with critical elements that differentiates it from that observed among traditional and nontraditional civilian students:

* $19 \%$ of students interact with military/veteran peers less than once a month

* $26 \%$ of students did not interact with military and veteran peers on campus

$14 \%$ of military and veteran peers interact: $2-3$ times a month; once a week; daily

$55 \%$ of military and veteran peers socialize off campus

$54 \%$ of military and veteran peers share a meal

$45 \%$ of military and veteran peers discuss personal feelings and problems

* $42 \%$ of military and veteran peers study together

* $57 \%$ of military and veteran peers give advice and information to each other

* $40 \%$ of military and veteran peers indicate they encourage each other

$33 \%$ of military and veteran peers help others in their peer group

$30 \%$ of military and veteran peers provide guidance to others in their peer group

$49 \%$ of military and veteran peers assist group members thinking of dropping out of college

* $45 \%$ of military and veteran peers assist others with academic problems, difficulty with the curriculum, not getting good advice from academic advisors, problems with the administration, stress management, sobriety, family problems

Camaraderie is a support network that most service members and veterans either know about or have experienced at some point in their military careers. Is it easily understood by civilians? A resounding no, would probably be their answer. A definition for camaraderie was developed from students' feedback on the online survey (Appendix H). According to focus group 
members at a military friendly school a semblance of camaraderie exists in higher education among the military student community.

Some military members /veteran peers frequently interact with each other during the month or as little as once a month. Others do so regularly during the school year, daily or more times in the week. On the other hand a larger group report they don't interact in any way on campus. The reason for this was not apparent because this follow up question wasn't asked in the present study, which should be anticipated in a future research.

The peers that do, strengthen their bond over time in ways that are personally meaningful, and help alleviate isolation and alienation within the campus culture. They give advice and information, discuss problems, listen to some vent, socialize, share a meal together, and be engrossed in study sessions. The characteristics of support amplify in camaraderie as these peers encourage, help, guide, and assist others they have a lot in common with stemming from their military backgrounds, which doesn't necessarily have to mean they served in the same branch of the Armed Forces.

It is probable camaraderie has some impact on decreasing the attrition of military members and veterans in college, which is a recommendation for another future study. In the meantime, these peers report they have assisted group members thinking of dropping out of college, experiencing academic problems and difficulty with the curriculum, not getting good advice from academic advisors, and problems with the administration. Assistance is not always as simple as working out at the gym or scheduling study time, it expands to serious and personal issues such as: stress management, sobriety, and family problems.

The quality of integration in the civilian culture is affected (Buser, 2008) placing a student at risk of not possibly achieving their academic goals. CAM 1, a veteran, former work 
study student in the Veterans Office at a military friendly designated university, and now recent college graduate emphasized one of the valuable tenets of camaraderie, "We won't let each other fail.” A good camaraderie system will help advance students' education goals. CAM 4 elaborates on his own experience, "I was only going to finish my bachelor's and call it quits. Now it's like, you know what? I'm going to go ahead and go for the master's. This is a good school, and I like the people here, and it's a good group that we have come here, so I'm going to stick with them to pursue my education."

Focus group members raised the topic of the 'Lone Wolf' in conjunction to camaraderie. It is a little known aspect of military members' and veterans' reintegration which impacts some students' transitions from the Armed Forces to college especially from a climate of war. In the present study, it is best described as the duration of time each individual determined was effective to manage the scope of experiences gained in the Armed Forces, and their comfort level of engaging with others in society during reintegration. CAM 4 provides clarity about the Lone Wolfe:

I had to decompress before I even started school. I got on my bike and wanted to ride a couple of thousand miles. I had to put a lot of stuff down. A lot of vets have to do that. We call it the lone wolf. When I hear about a new cat on campus and they're a vet doing that lone wolf I don't have a problem with it, because I've been there. Everybody has different experiences, no time frame [to decompress]. Somebody could come off of a rotation in Iraq and literally in three days they just let it wash off. Another person in that same squad could come off that same rotation and it may take years. We let them deal with it and when people need help or show signs they need help then we can say, "Hey, you want to talk buddy? 
How are things going?"

Some military and veteran students contend with issues such as Post Traumatic Stress Disorder (PTSD), Traumatic Brain Injury (TBI), depression, and physical disabilities in addition to other personal difficulties that infuse the quality of their transition (Church, 2009). Reintegration for some escalate into "emotional highs and lows," self-destructive behaviors, reliance on alcohol or drugs, chain smoking, uncontrollable anger, instances of rage, bouts of sleeplessness and blackouts, trouble with the law and jail time (Zing \& Cohen, 2010, pp. 42-45).

The military members who were involved in the Global War of Terror and enrolled in college shared common ground on personal, academic, and social issues during transition (Bissell, 2013; Wounded Warriors, 2012). This bond has been found to forge a unifying and supportive alliance (Money, 2011). Chickering and Reisser (1993) offered their perspective on the holistic nature of students' engagement in college such as the military student community and others 'to learn, students' basic needs such as nutrition, physical well-being, social support, and a sense of community, must be met" (Evans, Forney, \& Guido-DiBrito, 1998).

It seems camaraderie resonated with focus group members because each one was affected by its intangible benefits in their student life with a reciprocal effect observed many times over during the semesters leading up to their long, awaited graduation dates. Texas, provides this perspective of her peer group, “They've given me a lot of guidance and a lot of support that I don't think I would've found anywhere else and they help."

The camaraderie relationship has been referred to as a viable component of this subpopulation's coherence on campus (Ackerman, DiRamio, \& Mitchell, 2009; Green, 2012; Murphy, 2011; Naphan, 2011). Normandin (2010) reported student veterans felt they did not 
have a support system comparable to what they experienced during military service. They had to face the reality of having an "absent support system" (p. 75). This hindered their interactions with civilians in general experiencing a form of 'culture shock' even more so than "being in Iraq" (Carne, p. 111).

Rumann (2010) indicated that some military students felt disconnected to people not having military experience. Their camaraderie was empathetic to the extent they often stayed in touch with military veterans in their communities and those living out of state. This was similar behavior to that of focus group members in the present research. Wheeler (2011) pointed out that veterans in college felt that their military peers were often the only ones that could relate to their issues or understood what they were going through. They felt comfortable seeking their advice and discussing personal matters which was also true of respondents in the present study.

\section{Surprising Outcomes}

It was unexpected to observe one of my assumptions become reality, Student service members and student veterans wanted their perceptions known to academicians, researchers, and stakeholders supporting military friendly campus initiatives. The data spoke to me not once but many times over as I reviewed focus group members' comments and was surprised to read the feedback of military and veteran students on the online survey especially in the open-ended questions. They had a lot to say, and I for one was glad to hear their voices. Sometimes their voices were raised in unison in wanting certain accommodations on campus from seven geographic directions and sometimes it was the one voice that said something so profound (in my estimation) that it can’t be silenced so easily.

I purposely used the word "failure" to gauge students' assessment of their commitment to a goal that is not always easily accomplished by many; to persevere in college despite all odds and 
get that degree. They have already accomplished that in their first career in the military if they are a veteran or in the case of active duty service members they still do since they likely confront uncertainties daily in their job. With this in mind, I was surprised to see a good number of people write 'I will not fail.'

Students' Disagree/Agree answers on the Likert scale was revealing. I didn't determine that selection was due to uncertainty.

The focus group experience and the veterans that participated on that day unknowingly taught me the meaning of camaraderie. I observed and heard the reality of that definition in the context of higher education. It can never be equated to the kind of camaraderie service members experience in the military. It seems best not to explain it to a civilian.

At the end of the focus group I gave each group member an envelope containing my business card and gratuity. I was told beforehand the veterans did not want or expect anything in return for meeting with me since they all volunteered. I stopped each person and placed the envelope in their hand so they didn't have a choice but to take it. As each veteran left the room they stopped in front of Texas (the only female veteran in the focus group) and silently gave her their envelopes and walked out the door. The work study veteran pulled me aside to let me know that Texas has a young son and was having a tough time financially.

\section{Conclusions}

Based on past research I expected student service members and student veterans will probably report some negative experiences and perceptions of their transitions in college. Focus group members and the online respondents have a lot of similarities in their answers which served a confirmation and complementary purpose in triangulation of the data.

Veteran advocates/coordinators/directors received praise from the military community 
they served. They were part of students' good transition experiences. When respondents were given leeway to share what they thought I surmised they weren't restrained in their answers and honestly shared details of their transition in college to help resolve or eradicate problems that future student service members and student veterans may contend with. Some of the data seemed repetitive of other researcher's findings although students did have a concept of the feel and treatment of a school's military friendliness. The military friendly brand of services does appear to have value to the military student community.

The issues two focus group members each experienced with their faculty members on separate occasions indicate that sensitivity training would facilitate improvement in the interactions between students and faculty. Keep in mind these men and women transition from a military culture that honors respect for the most part.

Camaraderie received attention in this research that other studies mentioned in passing yet not elaborated upon. The characteristics associated with this phenomenon deserves a second look with a study focused entirely on its value in higher education.

\section{Implications for Action}

* Students' request for the same services and considerations need to be timely addressed by institutions that profess to be military friendly. Resolving the relevant issues should not take years. Set time limits from the federal level down to the academic environment. Intervention and monitoring by stakeholders or their representatives are needed at every institution that accepts G.I. Bill funds. It is also another way of creating jobs for military members, veterans and their dependents that graduate from college and viewed as public service positions. 
Military student research needs to be implemented in the curriculum and valued by research intensive higher education institutions.

* Military members, veterans and dependents with college degrees should have priority in hiring for jobs assisting military personnel in the areas of higher education, military TAP, and liaison roles.

* Raise funding and write grants for veterans lounges, housing, parking, and campus special events that honor and recognize student service members, student veterans, dependents on campus

* Seek out faculty (and those retired) with military history to serve as mentors and tutors

* A continual cycle of evaluation is needed by each institution that identifies itself as military friendly and particularly gauge students' perceptions

* Set an initiative to seek out individuals who are proactive in military/veteran issues in higher education that will advocate at the higher education, local government, state, and federal levels

\section{Recommendation for future research}

- The impact of priority registration on the persistence and retention of military members/veterans in higher education

○ Military dependents in higher education

- The impact of the veterans lounge on students' behavior and motivation

○ The impact of mentor relationships with military students

○ Comparison between military friendly schools and dedicated military friendly schools

\section{Concluding remarks}


The friendliness of higher education institutions is very subjective as students will differ in their perceptions. How they are treated is important. What is true for one individual may not be so for another. This was apparent in the information respondents shared which is based on their personal experiences and the quality of their transitions. The focus group found a good fit in the institution they selected. Respondents in the survey differed in this aspect.

No one mentioned dropping out although being on 'hiatus' according to one student's comment may be due to that individual's timing of separation from the military and length of time in civilian reintegration. The majority of students began their programs in higher education within the two-year time frame in which they had longer adjustment periods to the diversity of civilian life they returned to from the Armed Forces. They seemed to have some sense of balance in their student and personal lives and have found ways of coping with challenges and barriers. They seek out activities that help their development which give meaning and satisfaction to their progression in academia. Students' risks of failure appear to be low at military friendly schools.

\section{Insights}

During the first year of my doctoral program and working as an administrative graduate assistant for the McNair Scholars Program I happen to overhear a male student in the hallway discuss his frustrations with civilians with another student. Since they were standing right next to my office I decided to get up and shut the door. Before doing so, I noticed both men had backpacks covered in camouflage fabric and one of them was wearing a jacket depicting military service. I asked if I could possibly help them.

At first they shook their heads so I extended my hand and told them my husband was a 
veteran and that he would understand how they were feeling. In our conversation that followed I found out that Aiden was from my husband's hometown. Afterwards, in the first few months of our meeting Aiden stopped by my office almost weekly to vent about everything from his G.I. Bill process being slow, the behavior of civilian students in class, and to the parking attendant not understanding that he didn't have a dollar for parking and needed to be at class for an exam on time.

I became his unofficial sounding board since I was part of the university since I worked there but also not of the university since I was a student. He was often frustrated and I listened because I had undergone the same experience when my husband started as a full time college student. However, Aiden had been deployed numerous times in the Middle East, was a medic, and had very recently returned from overseas, less than a few weeks before starting the fall semester. He was eager to earn his degree and become a doctor, so he could re-enlist and return to help in a new capacity in the military. He missed the structure of military life and wasn't very tolerant of the easy-going campus culture he was immersed in. I also understood that he couldn't talk about the environment of war he had left behind and I never asked. Instead, I suggested that he contact my husband if he ever needed advice or just wanted to talk.

Aiden's issues were important enough to me that I developed my first pilot study about veterans in college in one of my research classes. I determined that interviews were best. Recruiting for participants proved to be difficult. I was so happy and tremendously relieved to have three people show up at their appointed times for the interview. Aiden was one of them. My pilot study set the precedent to have a dissertation that included military students.

Unfortunately, I lost touch with Aiden. The friend he was talking to on the day we first met dropped out of school the second semester he was in his program. He was also a medic and 
wanted to be a doctor too. Aiden always knew where to reach me when I worked at the McNair office. My husband tried to keep in contact with him although that was unsuccessful. Their relationship and camaraderie didn't take off as I expected. It may be due to the fact that my husband was an older veteran and Aiden was of a younger generation. Beside their bond of the military they each had something else in common, they each bore the physical and invisible scars of service to their country. In part, this work is dedicated to Aiden and others like him.

The best part about reading research on service members and veterans in college is when veterans' advocate/representative/liaison receive the accolades they deserve. It was difficult to find one that was not appreciated by those he or she served. Jerry McCarthy and Lisa Spencer began the roll call of special and caring military / veteran advocates that I had the privilege to be in contact with in addition to those from the five other schools that assisted in the continuity of the present study.

Student service members' and student veterans' feedback on the survey was not always negative. I found them insightful for the most part. They were offered an opportunity to have their say or vent in the open-ended questions regarding expectations of military friendly schools and their general experiences of college they wanted to share:

* Has a military clause/handbook that clearly states what happens if you miss class for deployments/training/etc...

* I actually do not know. I was trained to adapt to circumstance and so, I did.

* I have felt supported

* It should be easy to submit GI Bill forms, and the GI Bill should cover the cost of the school

* It needs to accept VA Benefits and understand the soldier 
* We are usually harder workers than our civilian counterparts

* The veterans' programs are all geared to young veterans who recently separated

* One that doesn't view you as another ATM machine like it does everyone else

Perhaps it is naïve to think that a military friendly school has students that exhibit camaraderie to the level that it appears to be an essential quality of balance in these student's lives during transition. In which this peer group find academic encouragement and personal motivation to raise the bar on their expectations in college. This exploration indicates that it is probable for some.

The veterans lounge was attributed by focus group members as the one resource of support they valued the most on campus. After spending a brief time in that room I understood their rationale:

I think this right here is really helpful...people come together. What we say in here doesn't go outside these walls. We can say our piece, get it off our chest, then laugh, joke about it, you know what? Next thing you know, it's all good. You know, by the end of the day, you're happy as all get up, you're heading home. In my case, drink a few on the porch and watch the dogs play. It's a good life.

This students' comment kept me centered on this research. "Please continue to be interested in veterans' voices, lots of suggestions can be assumed but by asking veterans you can get the most useful information. Thanks." 


\section{References}

Ackerman, R., \& DiRamio, D. (Eds.). (2009). Creating a veteran-friendly campus: Strategies for transition and success. New Directions for Student Services, 126. San Francisco, CA: Jossey-Bass.

Ackerman, R.L., DiRamio, D., \& Mitchell, R.L. (2009). Transitions: Combat veterans as college students. In R.L. Ackerman, \& D. DiRamio (Eds.), Creating a veteran-friendly campus: Strategies for transition and success (New Directions for Student Services); pp. 5-14. San Francisco, CA: Jossey-Bass.

Advisory Committee on Student Financial Assistance. (2012). Pathways to success. Integrating learning with life and work to increase national college completion. Retrieved from http://www2.ed.gov/about/bdscomm/list/acsfa/ptsreport2.pdf

Altheide, D. L., \& Johnson, J. M. (1994). Criteria for assessing interpretive validity in qualitative research. In N. K. Denzin \& Y. S. Lincoln (Eds.), Handbook of qualitative research (pp. 485-499). Thousand Oaks, CA: Sage Publications.

Altus, C. (2012, April). Minors matter. Military Advanced Education, 7(3), 7.

Altus, C. (2013, November). From battle zone to comfort zone. Military Advanced Education, $8(9), 19$.

Alvarez, L. (2008, November 2). Continuing an education: Combat to college. The New York Times. Retrieved from http://www.nytimes.com/2008/11/02/education/edlife/vets.html American Council on Education (2008, November). Serving those who serve: Higher education and America's veterans. Retrieved from http://www.acenet.edu/stws 
American Council on Education. (2009, July). Military service members and Veterans in higher education: What the new GI bill may mean for postsecondary institutions. Retrieved from ww.acenet.edu/Content/.../ProgramsServices/.../MilService.errata. American Council on Education (2011). Today's GI Bill. Retrieved from http://www.todaysgibill.org/todays-gi-bill/gi-bill-facts

American Council on Education. (2012). Today's GI Bill. Retrieved from http://www.todaysgibill.org/todays-gi-bill/gi-bill-facts/

American Council on Education. (2013). Toolkit for veteran friendly institutions.

Retrieved from https://vetfriendlytoolkit.acenet.edu/about/Pages/default.aspx

APSCU announces top priorities for reauthorization of the higher education act. (2013, April). Military Advanced Education, 8(3), 15.

Astin, A. W. (1984). Student involvement: A developmental theory for higher education. Journal of College Student Personnel, 25, 297-308.

Astin, A. W. (1993). What matters in college? San Francisco, CA: Jossey-Bass.

Astin, A.W. (1999). Student involvement: A developmental theory for higher education. Journal of College Student Development, 40(5).

Baker, S. (2013, August). 8 Keys to success: Supporting veterans, military and military families on campus. The White House Blog. Retrieved from http://www.whitehouse.gov/blog/2013/08/13/8-keys-success-supporting-veteransmilitary-and-military-families-campus

Ballantine, J. H. \& Hammack, F. M. (2009). The Sociology of education: A systemic analysis ( $6^{\text {th }}$ ed.). Upper Saddle River, NJ: Pearson.

Batungbacal, A., Erwin, J., \& Thompson, T. (2013, July 17). We stand up for women veterans. The Official Blog of the U.S. Department of Labor. 
Bazely, P. (2004). Issues in mixing qualitative and quantitative approaches to research. In. R. Buber, J. Gadner, \& L. Richards (Eds.), Applying qualitative methods to marketing management research (pp. 141-156). UK: Palgrave Macmillan.

Bissell, J. B. (2012, October). Serving those who served. Military Advanced Education, 7(8), 8.

Bissell, J. B. (2013, October). A call to the classroom. Military Advanced Education, 8(8), 6-7.

Blumenstyk, G. (2006, July 7). The military market: As more colleges pursue service members as students, concerns grow about overly aggressive tactics. The Chronicle of Higher Education. Retrieved from http://www.chronicle.com/weekly/v52/i44/44a02501.htm

Bourdieu, P. (1983). Forms of capital in J. C. Richards (ed.). Handbook of theory and research for the Sociology of education. New York, NY: Greenwood Press.

Braxton, J. M., McKinney, J. S., \& Reynolds, P. J. (2006). Cataloging institutional efforts to understand and reduce college students departure. New Directions for Institutional Research, 2006 (130), 25-32.

Brint, S., \& Karabel, J. (1989). The diverted dream. Community colleges and the promise of educational opportunity in American 1900-1985. New York, NY: Oxford University Press, Inc.

Broad, M. C. (2008, July). Going beyond the GI Bill. Inside Higher Ed. Retrieved from http://insidehighered.com/views/2008/07/11/broad

Buser, C. (2008, July). Working with returning Veterans. Retrieved from http://www.towson.edu/veterans/documents/3rdCombattoCollegeVABeneftits.pdf

Capps, T. K. (2011). Veteran students: What motivates persistence from matriculation to goal completion (Doctoral dissertation). Available from ProQuest Dissertations and Theses database. (UMI No. 3439499) 
Carne, G. L. (2011). Coming back to college: Middle East veteran student involvement and culture shock (Doctoral dissertation). Available from ProQuest Dissertations and Theses database. (UMI No. 3449946)

Cate, C. A., Gerber, M. M., \& Holmes, D. L., (2009). Student stressors in higher education: A pilot study. Retrieved from http://www.uweb.ucsb.edu/ chriscate/CateISTSS25.pdf.

Cate, C.A. (2011). Student veterans' college experiences: Demographic comparisons, Difference in academic experiences, and on-campus service utilization. (Doctoral dissertation). Available from ProQuest Dissertations and Theses database. (UMI No. 3481950).

Center for Women Veterans. (2010). Statistics. Retrieved from http://www.va.gov/womenvet/statistics.asp

Chickering, A. W. (1989). Improving higher education environments for adults: Responsive programs and services from entry to departure. San Francisco, CA: Jossey-Bass.

Chickering, A. W., \& Reisser, L. (1993). Education and identity (2nd ed.). San Francisco, CA: Jossey-Bass.

Church, T. E. (2009). Returning veterans on campus with war related injuries and the long road back home. Journal of Postsecondary Education and Disability, 22(1). 43-52.

Clark, K. (2008, June 17). The surprising history of military college benefits. U.S. News \& World Report. Retrieved from http://www.usnews.com/education/articles/2008/06/17/the-recent-history-ofmilitary-college-benefits_print.html

Clark, V. L. \& Creswell, J. (2008). The mixed methods reader. Los Angeles, CA: Sage Publications, Inc.

Cleveland State University. (2013). The veteran student success program. Retrieved from http://www.csuohio.edu/studentlife/vikingvets 
Coleman, J. C. (1988). Social capital in the creation of human capital. American Journal of Sociology, 94, S95-S120.

Coleman, J. C. (1990, 1994). Foundations of social theory. Cambridge, Mass.: Harvard University Press.

Cook, B. J., \& Kim, Y. (2009, July). From soldier to student: Easing the transition of service members on campus. Washington, DC: American Council on Education.

Creswell, J. W. (2009). Research design: Qualitative, quantitative, and mixed methods approaches (3rd ed.). Thousand Oaks, CA: SAGE Publications.

Cutrona, C. E., \& Russell, D. W. (1987). The provisions of social relationships and adaptation to stress. Advances in Personal Relationships, 1, 37-67.

Dao, J. (2013, February). A million strong: Helping them through. The New York Times. Retrieved from http://www.nytimes.com/2013/02/03/education/edlife/

DeGroat, A. S. \& Crowley, R. P. (2013). White paper: Looking critically at reintegration of post 9-11 era military veterans. Retrieved from https://www.k-state.edu/militaryaffairs/docs/Reintegrating-Post-9-11-Military-Veteran

Denzin, N. K., \& Lincoln, Y. S. (1998). Collecting and interpreting qualitative material. Thousand Oaks, CA: Sage.

Denzin, N. K. \& Lincoln, Y. S. (2000). Introduction: The discipline and practice of qualitative research. In N. K. Denzin \& Y. S. Lincoln (eds.). Handbook of qualitative research (2nd ed.). Thousand Oaks, CA: Sage, 1-28.

de Vise, Daniel. 2011. US falls in global rankings of young adults who finish college. The Washington Post. Retrieved from http://www.washingtonpost.com/local/education/us Dickson, P., \& Allen, T. B. (2004). The bonus Army: An American epic. New York, NY: Walker \& Company. 
DiRamio, D., Ackerman, R., \& Mitchell, R. (2008). From combat to campus: Voices of studentveterans. $N A S P A, 45(1), 73-102$. Retrieved from http://www.ebscohost.com/academic/education-research-complete

DiRamio, D., \& Jarvis, K. (2011). Veterans in higher education: When Johnny and Jane come marching to campus. Ashe Higher Education Report, 37(3).

Doenges, T. J. (2011). Calling and meaningful work among student military veterans: Impact on well-being and experiences on campus (Unpublished doctoral dissertation). Colorado State University, Fort Collins, CO.

Dungy, G. (2009, November/December). Military matriculation. Talking Stick, 27(2), 36-43. Retrieved from http://www.nxtbook.com/nxtbooks/acuho/talkingstick_20091112/\#/40

Eagle, H., \& Bailey, H. (2013, October). The civilian transition. Military Advanced Education, $8(8), 21-24$.

Eckel, P. D., \& King, J. E. (2006). An overview of higher education in the United States diversity, access and the role of the marketplace. International handbook of Higher Education. New York, NY: Springer.

Eisner, E. W. (1997). The new frontier in qualitative research methodology. Qualitative Inquiry, 3(3), 264.

Elliot, M., Gonzalez, C., \& Larsen, B. (2011). U.S. military veterans transition to college: Combat, PTSD, and alienation on campus. Journal of Student Affairs Research and Practice, 48(3), 279-296. Retrieved from http://www.journals.naspa.org/jsarp/vol48/iss3/art2/

Evans, N. J., Forney, D. S., \& Guido-DiBrito, F. (1998). Student development in college. San Francisco, CA: Jossey-Bass.

Field, K. (2008, July). Cost, convenience drive veterans' college choices. The Chronicle of Higher Education. Retrieved from http://chronicle.com/weekly/v54/i46/46a00101.htm 
Field, K. (2008, August). Good news for veterans in higher education bill. The Chronicle of Higher Education. Retrieved from http://chronicle.com/article/Good-News-for-Veterans-in/41409

Fisher Institute for Wellness and Gerontology. (2013). A closer look at the 7 dimensions of wellness. Retrieved from http://www.cms.bsu.edu/academics/centersandinstitutes/wellness/about/closerlook7dim

Fodel, K. (2012, December). Supporting the distance learning student. Military Advanced Education, 7(10), 53-56.

Friedman, B. (2012, March). VA takes action to address post-9/11 GI bill concerns. Vantage point dispatches from the U.S. Department of Veteran Affairs [Web log comment]. Retrieved from http://www.blogs.va.gov/VAntage/6074/va-takes-action-to-address- post-911-gi-bill-

Gebhart, S. (n.d.). Veterans on campus: The new G.I. bill and more. Veterans education and training program. West Virginia Higher Education Policy Commission.

Goldbloom, G. (2011). The paperbark shoe. New York, NY: Picador.

Goodman, B. (2005). Bringing the battle home. Psychology Today, 38(4), 40.Retrieved from EBSCOHOST.

Green, J. C., \& Caracelli, V. J. (Eds.). (1997). Advances in mixed-method evaluation: The challenges and benefits of integrating diverse paradigms. New Directions for Evaluation, 74. San Francisco, CA: Jossey-Bass.

Green, L. A. (2012). Identity and meaning making of student veterans transitioning to college (Unpublished doctoral dissertation). Texas Tech University, Lubbock, TX. Greenberg, M. (2008, July 25). The new GI bill is no match for the original. The Chronicle of Higher Education. Retrieved from http://www.chronicle.com/weekly/v54/i46/46a05601 
Greenbert, M. (2004, June 18). How the GI bill changed higher education. The Chronicle Review of Higher Education. Retrieved from http://chronicle.com/article

Grbich, C. (2007). Qualitative data analysis: An introduction. Thousand Oaks, CA: Sage Publications, Inc.

Hadley, S., Trechter, D., \& Parks, D. (2011, April ). UWRF veterans survey report, 2011. Retrieved from http://www.uwrf.edu/SurveyResearchCenter/upload/2011-UWRF.pdf

Herrmann, D., Raybeck, D., Wilson, R., Allen Jr., B., \& Hopkins, C. (2008, November ). College is for veterans, too. The Chronicle of Higher Education, p. A33.

Hershberg, T. (1996, March). Human capital development: America's greatest challenge. The ANNALS of the American Academy of Political and Social Science, 544(1), 43-51. Retrieved from http:/www.cgp.upenn.edu/pdf/Human\%20Capital\%20Development.pdf Hewson, C. (2003, June). Conducting research on the internet. The Psychologist, 16(6). Retrieved from http://ethics.grad.ucl.ac.uk/forms/hews_psychol.pdf Hobbes, L. (2012, September). Military-friendly colleges go the extra mile to help their deployed students succeed academically. Military Advanced Education, 7(7), 9-11.

Hollis, M. J. (2009). Breaking down cultural barriers to military entry into higher education. Retrieved from http://www.eric.ed.gov/PDFS/ED511502.pdf

Howell, T. (2012, April). What does ‘military friendly' mean? Retrieved from http://militaryadvantage.military.com/2012/04/what-does-military-friendly-mean/

Iraq and Afghanistan Veterans of America. (2012, March). IAVA 2012 member survey. Survey response external summary. Retrieved from http://media.iava.org/iava_2012_member_survey.pdf

Kazis, R. (2006). Building a pipeline for college access and success. The Journal of the New England Board of Higher Education, 20(4), 13-15. 
Kim, Y. M., \& Cole, J. S. (2013). Student veterans/service members' engagement in college and university life and education. Retrieved from http://www.acenet.edu/news-room Documents/Student-Veterans-Service-Members-Engagement.pdf

Knefelkamp, L., Widick, C. \& Parker, C. (1978). Applying new developmental findings. New Directions for Student Services, 4. San Francisco, CA: Jossey-Bass.

Kreuger, R. A. (1994). Focus groups: A practical guide for applied research (2nd ed.). Newbury Park, CA: Sage.

Kvale, S., \& Brinkmann, S. (2009). Interviews: Learning the craft of qualitative research interviewing ( $2^{\text {nd }}$ ed.). Thousand Oaks, CA: Sage Publications, Inc.

Laanan, F. S. (2000). Community college students' career and educational goals. New Directions for Community Colleges, 112, 19-33.

Lang, W. A., Harriett, B. D., \& Cadet, M. (2013, November). Completing the mission II: A study of veteran students' progress toward degree attainment in the post 9/11 era. Retrieved from http://www.operationpromiseforservicemembers.com/Completing_Mission_II.

Lang, W. A., \& Powers, J. T. (2011, November). Completing the mission: A pilot study of veteran students' progress toward degree attainment in the post 9/11 era. Retrieved from http://www.miracosta.edu/studentservices/veteransinfocenter/downloads/Completing-

Lederman, D. (2008, February). What makes a college military friendly? Inside Higher Ed. Retrieved from http://www.insidehighered.com/layout/set/print/news/2008/02/22/

Lederman, D. (2008, June). Preparing for an influx. Inside Higher Ed. Retrieved from http://www.insidehighered.com/layout/set/print/news/2008/06/06/vet

Livingston, W. (2009). Discovering the academic and social transitions of re-enrolling student veterans at one institution: A grounded theory (Doctoral dissertation). Available from ProQuest Dissertations and Theses database. (AAT 3355150). 
McBain, L., Kim, Y. M., Cook, B. J., \& Snead, K. M. (2012, July). From soldier to student II: Assessing campus programs for veterans and service members. American Council on Education. Retrieved from http://www.acenet.edu/news-room/Documents/From-Soldier-to-Student-II-Assessing-

McCarthy, M. (2012, April). Military advanced education. Journal of Higher Learning for Today's Servicemember, 7(3), 2.

McLaughlin, J. (2011). What is a brand, anyway? Retrieved from http://www.forbes.com/sites/jerrymclaughlin/2011/12/21/what-is-a-brand-anyway

Mercer, D. (n.d.). College-bound vets say campus needs often unmet. The Associated Press. Retrieved from http://www.armytimes.com

Military Advanced Education (2012, April). The military and veterans educational reform act of 2012. Journal of Higher Learning for Today's Servicemember, 7(3).

Military Family Research Institute. (2013). Education and employment initiative of MFRI. Retrieved from http://www.cfs.purdue.edu/mfri/public/default.aspx.

Money, N., Moore, M., Brown, D., Kasper, K., Roeder, J., Bartone, P., \& Bates, M. (2011, January). Identification of best practices in peer support: White paper. Defense Centers of Excellence for Psychological Health \& Traumatic Brain Injury. Retrieved from http://www.dcoe.health.mil

Morreale, C. (2011). Academic motivation and academic self-concept: Military veteran students in higher education (Doctoral dissertation). Available from ProQuest Dissertations and Theses database. (UMI No. 3460783)

Murphy, P. M. (2011). Military veterans and college success: A qualitative examination of veteran needs in higher education. (Unpublished doctoral dissertation). University of North Carolina at Greensboro, Greensboro, NC. 
Naphan, D. (2011). From soldier, to civilian, to student: Student veterans' transitions from overseas deployments to the university classroom. (Master's Thesis). Available from ProQuest Dissertations and Theses database. (UMI No. 1494176)

National Center for Veteran Analysis and Statistics. (2010). Percent change in veteran population by state. Retrieved from http://www.va.gov/vetdata docs/Maps/VetPop

Normandin, K. (2010). Contemporary student veterans: Transitional experiences from military life to college life (Unpublished master's thesis). Oregon State University, Corvallis, OR.

Northrup, P. (2013, December). Priority enrollment for service members returning to college. Military Advanced Education, 8(10), 69.

Palm, E. F. (2008, September 19). The veterans are coming! The veterans are coming! Retrieved from http://www.insidehighered.com/layout/set/ print/views/2008/09/palm

Paterson, B. L. (1994, June). A framework to identify reactivity in qualitative research. Western Journal of Nursing Research, 16(3), 301-316.

Patton, M.Q. (2002). Qualitative research \& evaluation methods (3rd ed.). Thousand Oaks, CA: Sage Publications Inc.

PBS. (2013). Primary resources: JFK's inaugural speech. Retrieved from http://www.pbs.org/wgbh/americanexperience/features/primary-resources/Kennedysinaugural-speech

Persky, K. R. (2011). Veterans coming home to the community college: Linking research to practice. Community College Journal of Research and Practice, 35, 111-120.

Peterson, M. W., \& Spencer, M. G. (1990, Winter). Understanding academic culture and climate. W.G. Tierney (Ed.). New Directions for Institutional, 68, 3-18.

Plano Clark, V. L., \& Creswell, J. W. (2008). The mixed methods reader. Thousand Oaks, California: Sage Publications. 
Presidential Documents 25861 (2012, April). Establishing principles of excellence for educational institutions serving service members, veterans, spouses, and other family members. Federal Register, 77 (85) /Wednesday, May 2, 2012 / Presidential Documents 25861 http://www.gpo.gov/fdsys/pkg/FR-2012-05-02/pdf/2012-10715.pdf

Raz, G. (2006, November). Defining the war on terror. Retrieved from http://www.npr.org/templates/story/story.php?storyId=6416780

Rea, C. P. (2011). Veterans in transition: From a combat zone to college (Doctoral dissertation). Available from ProQuest Dissertations and Theses database. (UMI No. 1504).

Redden, E. (2009). Campus as vet friendly zone. Inside Higher Ed. Retrieved from http://www.insidehighered.com/news/2009/06/05/veterans

Rendon, L. (1996). Educating a new majority. San Francisco, CA: Jossey-Bass.

Riessman, C. K. (2002). Analysis of personal narratives. In handbook of interview research:

Context and method. J. F. Gubrium and J. A. Holstein (Eds.). Thousand Oaks, CA: Sage.

Riessmann, C. K. (2008). Narrative methods for the human sciences. Thousand Oaks, CA: Sage.

Rogers, B. (2009, Spring). Returning Iraq war veterans: And new national attention to VUB services. COE NETWORKS, 65-67.

Rosenbaum, J. (2001). Beyond college for all. Career paths for the forgotten half. New York, NY: American Sociological Association.

Rudd, M. D., Goulding, J., \& Bryan, C. J. (2011, Oct). Student veterans: A national survey exploring psychological symptoms and suicide risk. Professional Psychology: Research and Practice, 42(5), 354-360. doi: 10.1037/a0025164

Rumann, C. B., \& Hamrick, F. A. (2009). Supporting student veterans in transition. New Directions for Student Services, (126), 25-34. Retrieved from EBSCOHOST.

Rumann, C. B. (2010). Student veterans returning to a community college: Understanding their transitions (Doctoral dissertation). Available from ProQuest Dissertations and Theses database. (UMI No. 3403830) 
Rumann, C. B., \& Hamrick, F. A. (2010). Student veterans in transition: Re-enrolling after war zone deployments. The Journal of Higher Education, 81(4), 431-458. Retrieved from EBSCOHOST.

Russell, D., Cutrona, C. E., Rose, J., \& Yurko, K. (1984). Social and emotional loneliness: An examination of Weiss's typology of loneliness. Journal of Personality and Social Psychology, 46(6), 1313-1321.

Sadovnik, A. R. (2007). Sociology of education: A critical reader, (Ed.). New York, NY: Routledge

Salkind, N. J. (2008). Statistics for people who (think they) hate statistics $\left(3^{\text {rd }}\right.$ ed.). Thousand Oaks, CA: Sage Publications, Inc.

San Diego State University. (2013). The Joan and Art Barron veterans center. Retrieved from http://www. arweb.sdsu.edu/es/veterans

Sanford, N. (1962). The American college. New York, NY: Wiley.

Sanford, N. (1966). Self and society: Social change and individual development. New York, NY: Atherton.

Sapsford, R. (2007). Survey research ( $2^{\text {nd }}$ ed.). Thousand Oaks, CA: Sage Publication Inc. Schiavone, V. (2013). Veteran-students in transition at a Midwestern university. (Unpublished master's thesis). University of Toledo, Toledo, $\mathrm{OH}$.

Schlossberg, N. K., Lynch, A. Q., \& Chickering, A.W. (1989). Improving higher education environments for adults: Responsive programs and services from entry to departure. San Francisco, CA: Jossey-Bass.

Schroeder, S. (2011, March). Foreward. Student success in higher education (p. 1). AFT Higher Education. Retrieved from http://www.aft.org/pdfs/highered/studentsuccess0311.pdf

Seidman, A. (Ed.). (2005). College student retention: Formula for student success. Westport, CT: Praeger. 
Servicemembers Opportunity Colleges. (2008). Servicemembers opportunity colleges:

Providing educational opportunity to servicemembers. Retrieved from http://www.soc.aascu.org

Sewall, M. (2010, June 13). Veterans use new G I bill largely at for-profit and 2-year colleges. The Chronicle of Higher Education.

Shackelford, A. L. (2009). Documenting the needs of student veterans with disabilities: Intersection roadblocks, solutions, and legal realities. Journal of Postsecondary Education and Disability, 22(1), 36-42.

Steigmeyer, R. (2009, February 21). From combat to college: A tough transition that few understand. The Wenatchee World. Retrieved from http://www.wenatcheeworld.com/news/2009/feb/21/from-combat-to-college-

Sternberg, M., Wadsworth, S. M., Vaughn, J., \& Carlson, R. (2009, April). The higher education landscape for student service members and veterans in Indiana. Retrieved from https://www.mfri.purdue.edu/resources/public/reports/HigherEducationLandscape.pdf

Stewart, T. A. (1997) Intellectual capital: The new wealth of organizations. New York, NY: Doubleday.

Student Veterans of America. (2009, January). Veteran center handbook for student veterans. Retrieved from http://www.studentveterans.org

Student Veterans of America. (2011). Chapters: Quick stats. Retrieved from http://www.studentveterans.org/chapters

Student Veterans of America. (2013). Veteran center handbook for student veterans. Retrieved from http://www.studentveterans.org

Terrell, S. (2011). Mixed-methods research methodologies. The Qualitative Report, 17(1), 254280. Retrieved from http://www.nova.edu/ssss/QR/QR17-1/terrell.pd

The GI Bill's history born of controversy: The GI bill of rights. Retrieved from 
http://www.gibill.va.gov/benefits/history_timeline/index.html

University of Arizona. (n.d.). Veterans education and transition services [VETS). Retrieved from http://vets.arizona.edu/ua/

U.S. Bureau of Labor Statistics. (2013). The employment situation-April 2013 (News Release

USDL-13-0785, May 3, 2013). Retrieved from

http://www.bls.gov/news.release/archives/empsit_05032013.pdf.

U.S. Bureau of Labor Statistics. (2013). Employment situation of veterans-2012 (News Release

USDL-12-0493, March 20, 2013). Includes Tables 1-9. Retrieved from

http://www.bls.gov/news.release/pdf/vet.pdf

U. S. Census Bureau (2010). Profile America: Facts for features. Retrieved from

http://www.census.gov/newsroom/releases/archives/facts_for_features_special_editions/cb1 $0-\mathrm{ff} 21 . h \mathrm{tml}$

U.S. Census Bureau. (2012). How do we know? A snapshot of our nation's veterans. Retrieved from http://www.census.gov/how/infographics/veterans.html

U.S. Department of Education. Office of the Assistant Secretary. (2008, July). So you want to go back to school. Retrieved from

http://www2.ed.gov/about/offices/list/ocr/letters/back-to-school-2008.html

U. S. Department of Education. (2011). Veterans upward bound program. Retrieved from http://www2.ed.gov/programs/triovub/index.html

U. S. Department of Education. (2012). National Center for Education Statistics (NCES). Retrieved from http://www.ed.gov/rschstat/facts.html

U.S. Department of Labor. (n.d.). Transition assistance programs. VETS fact sheet 1. Retrieved from http://www.dol.gov/vets/programs/tap/tap_fs.htm

U. S. Department of Labor. (2013). Symposium on women veterans' employment: skills matter. Retrieved from http://www.dol.gov/vets/womenveterans 
U.S. Department of Labor. Bureau of Labor Statistics (2013, March). Employment situation of veterans - 2012. Retrieved from http://www.bls.gov/news.release/pdf/vet.pdf

U.S. Department of Veterans Affairs. Education Service. (2001). The GI Bill: From Roosevelt to Montgomery. Retrieved from http://www.gibill.va.gov/benefits/history_timeline/index.html

U. S. Department of Veterans Affairs. Office of Policy and Planning. (2007, Sept.). Women veterans: Past, present, and future. Retrieved from http://wwwl.va.gov/womenvet/docs/womenvet_history.pdf

U.S. Department of Veterans Affairs. (2009). Retrieved from http://www.ed.gov/about/offices/list/ocr/letters/back-to-school-2008.html

U.S. Department of Veterans Affairs. (2010). Returning service members OEF/OIF/OND. Retrieved from http://www.oefoif.va.gov/education.asp

U.S. Department of Veterans Affairs. (2012). Federal benefits for veterans, dependents and survivors. Retrieved from http://www.va.gov/opa/publications/benefits_book.asp U.S. Department of Veterans Affairs. (2013). Yellow ribbon program. Retrieved from http://www.benefits.va.gov/gibill/yellow_ribbon.asp

Weiss, R. S. (1974). The provisions of social relationships. In Z. Rubin (Ed.), Doing unto others (pp. 17-26). Englewood Cliffs, NJ: Prentice-Hall.

Westat. (2013). 2013 Wounded warrior project survey: Report of findings. Retrieved from http://www.woundedwarriorproject.org/media/505955/2013- alumni- survey-results.pdf Westat. (2010, October). National Survey of Veterans, Active Duty Service Members, Demobilized National Guard and Reserve Members, Family Members, and Surviving Spouses. Final Report. Retrieved from http://www.va.gov/SURVIVORS/docs/NVSSurveyFinalWeightedReport.pdf 
West Virginia Department of Military Affairs and Public Safety (n.d.). Retrieved from http://www.wvdmaps.gov

West Virginia Division of Veterans Affairs (n.d.). Retrieved from http://elearn.wvu.edu/Military/vaoffices.php

Wheeler, H. A. (2011). From soldier to student: A case study of veterans' transitions to first-time community college students (Doctoral dissertation). Available from ProQuest Dissertations and Theses database. (UMI No. 3465899)

Willingham, T. (2008, May). Program helps veterans transition from soldiers to students. eSource, 5(5), 1-2, 13. Retrieved from www.nrc.fye.sc.edu/esource/ Esource5.5.pdf

Wilson, R. (1995). The G.I. Bill and the transformation of America. National Forum, 75(4), 20.

Wolfe, T. (2012). Military camaraderie in the civilian world? Retrieved from http://www.military.com/veteran-jobs/career-advice/on-the-job/military-camaraderieWomen In Military Service For America Memorial. (n.d.). Honoring military womenpast, present and future. Retrieved from http://www.womensmorial.org/About/history Zinger, L. \& Cohen, A. (2010, January). Veterans returning from war into the classroom: How can colleges be better prepared to meet their needs. Contemporary Issues In Education Research, 3(1). 


\section{APPENDIX A}

\section{WFINTO MILITARY FRIENDLY COLLEGE / UNIVERSITY SURVEY}

Q1 Did you seek information about Military Friendly Schools from any of the following websites to help in your selection of a College or University?

\section{Select all that apply}

G.I. Jobs

- Military Advanced Education

Militaryfriendlyschools.com

$\square$ Military Times Best For Vets

U.S. News \& World Report Best Colleges

College and University websites

None of the Above

$\square$ Other (please specify)

Q2 Why did you choose to attend your university / college?

\section{Select all that apply}

The Military Friendly Logo was displayed on this school's website

L Listed as a military / veteran friendly school on several websites

Always wanted to attend this school

Affordable

- Family member / friend attended this school

- Military member / Veteran recommended this school

$\square$ Convenient location

$\square$ Offer online courses that interest me

$\square$ Other (please specify) 
Q3 Indicate the services and resources available to veterans and military students at your university / college.

\section{Select all that apply}

$\square$ Waive or relax APPLICATION DEADLINES for military members who are deployed

Easy-to-use website that answers questions veterans and military students will have (includes point of contact listing)

- Waive APPLICATION FEES for veterans and military students

$\square$ Separate orientation session for incoming veterans and military members

- Counseling and therapy services for PTSD, TBI, Depression, readily available

C Career counseling

Office of Military / Veterans Affairs

V Veterans Lounge / One Stop Center

V Veteran Housing

$\square$ Other (please specify)

Q4 I have identified myself as a military member or veteran to...

\section{Select all that apply}

C Civilian students

Faculty

- Administrators

- Staff members

Other military members and veterans

a All of the Above

I don't identify myself as a military member or veteran to anyone on campus

I I identify myself only as a Student on campus

$\square$ Other (specify) 
Q5 Please indicate the services, resources and programs available for military members and veterans at your university / college.

\section{Select all that apply}

$\square$ Priority course registration

Academic Advisor experienced in helping military members and veterans

口 Processing of VA Education benefits

In-State Tuition for military members and veterans

Y Yellow Ribbon Program

College credit for courses taken during military service and training

- Student Veterans Chapter

- Veterans Advocate

Scholarships / Grants / Fellowships for military members and veterans

Buddy system-linking students with military experience

Mentoring Program with faculty having military experience

Other (please specify)

Q6 Is there a resource /service / or program you would like to see implemented at your university / college for military members and veterans that is still needed?

$\square$ None

$\square$ Other (please specify)

Q7 How would you describe a Military Friendly University / College that meets your personal expectations? 
Q8 Please indicate your perceptions of the following:

\begin{tabular}{|c|c|c|c|c|c|}
\hline & $\begin{array}{l}\text { Strongly } \\
\text { Disagree }\end{array}$ & Disagree & $\begin{array}{l}\text { Neither } \\
\text { Agree nor } \\
\text { Disagree }\end{array}$ & Agree & $\begin{array}{l}\text { Strongly } \\
\text { Agree }\end{array}$ \\
\hline $\begin{array}{l}\text { This is a Military Friendly } \\
\text { School. }\end{array}$ & $\square$ & $\square$ & $\square$ & $\square$ & $\square$ \\
\hline $\begin{array}{l}\text { My education goals are } \\
\text { expedited at a } \\
\text { Military Friendly School. }\end{array}$ & 口 & $\square$ & 口 & $\square$ & $\square$ \\
\hline $\begin{array}{l}\text { The support of resources, } \\
\text { services, and programs } \\
\text { available to veterans } \\
\text { and military members at this } \\
\text { university / college } \\
\text { will help me to graduate } \\
\text { with my degree. }\end{array}$ & 口 & 口 & 口 & $\square$ & 口 \\
\hline $\begin{array}{l}\text { The G.I. Bill is helping me } \\
\text { to achieve my college } \\
\text { education at this university / } \\
\text { college. }\end{array}$ & 口 & $\square$ & $\square$ & $\square$ & $\square$ \\
\hline $\begin{array}{l}\text { I would not enroll in a } \\
\text { university / college that did } \\
\text { not identify itself as being } \\
\text { military friendly. }\end{array}$ & 口 & 口 & a & a & $\square$ \\
\hline $\begin{array}{l}\text { My professional goals to } \\
\text { enter the civilian workforce } \\
\text { are expedited at a Military } \\
\text { Friendly School. }\end{array}$ & $\square$ & 口 & $\square$ & $\square$ & $\square$ \\
\hline $\begin{array}{l}\text { This is a military-inclusive } \\
\text { campus culture. }\end{array}$ & $\square$ & $\square$ & $\square$ & $\square$ & $\square$ \\
\hline
\end{tabular}


Q9 For the purpose of this research: SUCCESS is defined as the continual focus on the completion of coursework to attain a degree despite challenges, difficulties, or problems.

\begin{tabular}{|c|c|c|c|c|c|}
\hline & $\begin{array}{l}\text { Strongly } \\
\text { Disagree }\end{array}$ & Disagree & $\begin{array}{l}\text { Neither } \\
\text { Agree nor } \\
\text { Disagree }\end{array}$ & Agree & $\begin{array}{c}\text { Strongly } \\
\text { Agree }\end{array}$ \\
\hline $\begin{array}{l}\text { My success in pursuing my } \\
\text { education goals are easier than } \\
\text { expected due to my enrollment at a } \\
\text { Military Friendly university / } \\
\text { college. }\end{array}$ & $\square$ & $\square$ & $\square$ & $\square$ & $\square$ \\
\hline $\begin{array}{l}\text { I am happy with my progress } \\
\text { toward attaining my degree at } \\
\text { this university / college. }\end{array}$ & $\square$ & $\square$ & $\square$ & $\square$ & $\square$ \\
\hline $\begin{array}{l}\text { I am determined to complete my } \\
\text { degree at this university / college } \\
\text { despite personal or academic } \\
\text { challenges or difficulties I may } \\
\text { encounter. }\end{array}$ & $\square$ & $\square$ & $\square$ & 口 & $\square$ \\
\hline
\end{tabular}

Q10 Please describe why you may fail to complete your education at this university / college and not graduate with your degree.

Q11 My higher education path has included participation in...

\section{Select all that apply}

the Honors Program

McNair Scholars Program

- Student Support Services

V Veterans Upward Bound Program

S Study Abroad

$\square$ a Research conference

$\square$ an Academic conference

a Professional development seminar

$\square$ None of the Above

$\square$ Other (specify) 
Q12 Since enrolling in this university / college I ...

\section{Select all that apply}

Understand what my professors expect of me academically

Have developed effective study skills

- Have adjusted to the academic demands of college

Manage my time effectively

- Discussed my grades and/or coursework with faculty

$\square$ Figured out which requirements I need to graduate

Ask for help when I need it

$\square$ Have made friends

Have become involved in campus activities

- Attended school sponsored sports events

- Attended school sponsored academic lectures and discussions

$\square$ None of the Above

$\square$ Other (please specify)

Q13 My student life at this university / college has included...

\section{Select all that apply}

$\square$ a Service Learning Project / Community Service / Volunteering

service and leadership in Student Government

$\square$ membership in a Student Group

$\square$ attending Student Veterans Chapter meetings

- Academic / Research presentations

My name on the Dean's List

applications to Graduate Programs

$\square$ service as a Tutor

$\square$ service as a Mentor

$\square$ applications for Internships

a applications for Grants / Scholarships / Fellowships

$\square$ None of the Above

$\square$ Other (please specify) 
Q14 Please indicate your relationship with other military members and veterans on campus.

\begin{tabular}{|c|c|c|c|c|c|}
\hline & $\begin{array}{l}\text { Strongly } \\
\text { Disagree }\end{array}$ & Disagree & $\begin{array}{l}\text { Neither } \\
\text { Agree nor } \\
\text { Disagree }\end{array}$ & Agree & $\begin{array}{c}\text { Strongly } \\
\text { Agree }\end{array}$ \\
\hline $\begin{array}{l}\text { I share a close bond with military } \\
\text { members and veterans } \\
\text { on campus. }\end{array}$ & 口 & 口 & 口 & $\square$ & $\square$ \\
\hline $\begin{array}{l}\text { I have a peer support network } \\
\text { among military members and } \\
\text { veterans on campus. }\end{array}$ & $\square$ & $\square$ & $\square$ & $\square$ & $\square$ \\
\hline $\begin{array}{l}\text { The camaraderie I share with other } \\
\text { military members and veterans on } \\
\text { campus is relevant to my SUCCESS } \\
\text { as a student. }\end{array}$ & $\square$ & $\square$ & $\square$ & 口 & $\square$ \\
\hline $\begin{array}{l}\text { My adjustment from the military } \\
\text { to college has been made easier } \\
\text { due to the camaraderie I share } \\
\text { with other military members and } \\
\text { veterans on campus. }\end{array}$ & $\square$ & $\square$ & $\square$ & $\square$ & $\square$ \\
\hline $\begin{array}{l}\text { Other military members and } \\
\text { veterans on campus have helped me } \\
\text { to stay focused on my academic } \\
\text { goals. }\end{array}$ & $\square$ & $\square$ & $\square$ & $\square$ & $\square$ \\
\hline $\begin{array}{l}\text { Other military members and } \\
\text { veterans on campus have } \\
\text { encouraged me to graduate. }\end{array}$ & $\square$ & $\square$ & $\square$ & $\square$ & 口 \\
\hline
\end{tabular}

Q15 How often do you interact with military members and veterans on campus?

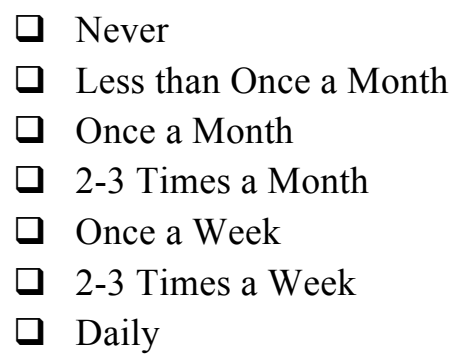


Q16 Please describe your bond with other military members and veterans on campus.

\section{Select all that apply}

$\square$ share a meal together

$\square$ discuss personal feelings and problems

a study together

socialize off campus

$\square$ attend school sponsored sports events together

$\square$ attend campus activities together

$\square$ always ready to help when needed

$\square$ Other (please specify)

Q17 How would you describe to a civilian what CAMARADERIE is as it relates to military members and veterans on campus?

Q18 I have assisted another military member or veteran on campus who was:

\section{Select all that apply}

$\square$ having health issues

$\square$ showing risky behavior (s)

$\square$ thinking of dropping out of school

Other (please specify)

Q19 Please indicate your branch of service...
O Army
O Navy
O Marine Corps
O Air Force
O Coast Guard
O Reserves
O National Guard

Q20 Please indicate the person in your family having a Bachelor's degree in college.
․ Mother
$\square$ Father
口 $\mathrm{Me}$
O Other
No One 
Q21 Rank in the military?

Enlisted

$\square$ Officer

Other (please specify)

Q22 Please indicate your higher education path.

\section{Select all that apply}

I took some college courses prior to enlisting in the Armed Forces.

I started my freshman year at this university / college.

I I transferred to this university / college.

I I am currently on active-duty and taking college courses.

I took some college courses during military service.

$\square$ Other (please specify)

Q23 Please indicate your perspective regarding your transition at your university / college. 


\begin{tabular}{|c|c|c|c|c|c|}
\hline & $\begin{array}{l}\text { Strongly } \\
\text { Disagree }\end{array}$ & Disagree & $\begin{array}{l}\text { Neither } \\
\text { Agree nor } \\
\text { Disagree }\end{array}$ & Agree & $\begin{array}{l}\text { Strongly } \\
\text { Agree }\end{array}$ \\
\hline $\begin{array}{l}\text { I experienced timely processing of } \\
\text { my G.I. Bill paperwork and } \\
\text { funds. }\end{array}$ & a & $\square$ & $\square$ & $\square$ & $\square$ \\
\hline $\begin{array}{l}\text { This school has accessible and } \\
\text { comfortable classroom learning } \\
\text { environments. }\end{array}$ & a & $\square$ & $\square$ & $\square$ & $\square$ \\
\hline $\begin{array}{l}\text { My professors and instructors are } \\
\text { respectful and considerate of } \\
\text { students with military experience } \\
\text { during lectures and class discussions. }\end{array}$ & $\square$ & $\square$ & $\square$ & $\square$ & $\square$ \\
\hline $\begin{array}{l}\text { The administrators, staff } \\
\text { members, and faculty should } \\
\text { receive special training in } \\
\text { supporting military members and } \\
\text { veterans on this campus. }\end{array}$ & $\square$ & $\square$ & $\square$ & $\square$ & $\square$ \\
\hline $\begin{array}{l}\text { I experienced some difficulty } \\
\text { relating to civilian students at first. }\end{array}$ & 口 & $\square$ & $\square$ & $\square$ & 口 \\
\hline $\begin{array}{l}\text { I experienced difficulty taking } \\
\text { quizzes, tests, and final exams. }\end{array}$ & 口 & a & $\square$ & $\square$ & $\square$ \\
\hline $\begin{array}{l}\text { My first semester as a college } \\
\text { student was challenging. }\end{array}$ & ص & ص & $\square$ & $\square$ & $\square$ \\
\hline $\begin{array}{l}\text { I needed to upgrade my writing } \\
\text { skills and knowledge of some basic } \\
\text { education courses. }\end{array}$ & $\square$ & $\square$ & $\square$ & $\square$ & a \\
\hline $\begin{array}{l}\text { Admission to this school was an easy } \\
\text { process. }\end{array}$ & ص & ص & $\square$ & 口 & 口 \\
\hline $\begin{array}{l}\text { I have identified a knowledgeable } \\
\text { person on campus to serve as my } \\
\text { mentor. }\end{array}$ & $\square$ & $\square$ & $\square$ & $\square$ & $\square$ \\
\hline $\begin{array}{l}\text { Veterans only classes have helped } \\
\text { me to adjust to college. }\end{array}$ & $\square$ & 口 & 口 & 口 & 口 \\
\hline $\begin{array}{l}\text { I just want to blend in with other } \\
\text { students. }\end{array}$ & $\square$ & 口 & $\square$ & $\square$ & 口 \\
\hline I was prepared for college. & $\square$ & $\square$ & $\square$ & $\square$ & $\square$ \\
\hline I have not adjusted to college. & $\square$ & $\square$ & $\square$ & $\square$ & $\square$ \\
\hline $\begin{array}{l}\text { I have responsibilities in addition to } \\
\text { college courses and don't have time } \\
\text { to participate in many campus } \\
\text { activities. }\end{array}$ & ص & $\square$ & $\square$ & $\square$ & $\square$ \\
\hline
\end{tabular}


Q24 How many credit hours in:

\begin{tabular}{|r|c|c|c|c|c|c|c|}
\hline & 6 & 9 & 12 & 15 & 18 & 21 & 24 \\
\hline 2013 Fall Semester & $\square$ & $\square$ & $\square$ & $\square$ & $\square$ & $\square$ & $\square$ \\
2014 Spring Semester & $\square$ & $\square$ & $\square$ & $\square$ & $\square$ & $\square$ & $\square$ \\
\hline
\end{tabular}

Q25 What is your expected graduation date? Semester and Year

Q26 Military members and veterans at this university / college...

\section{Select all that apply}

will give advice or information to each other

have the assurance that members in their group can be counted on in times of stress

$\square$ have recognition of each other's competence

a share an emotional closeness

$\square$ have a sense of belonging to a group of friends

$\square$ provide assistance to group members if needed

$\square$ None of the Above

$\square$ All of the Above

$\square$ Other (please specify)

Q27 Some military members and veterans at this university / college have provided other students with military experience...

\section{Select all that apply}

$\square$ Help

- Guidance

Emotional Support

- Encouragement

a All of the Above

a None of the Above

$\square$ Other (please specify) 
Q28 To prepare for my transition from the Armed Forces to the civilian community and college, I ...

\begin{tabular}{|c|c|c|c|c|c|}
\hline & $\begin{array}{l}\text { Strongly } \\
\text { Disagree }\end{array}$ & Disagree & $\begin{array}{l}\text { Neither } \\
\text { Agree nor } \\
\text { Disagree }\end{array}$ & Agree & $\begin{array}{l}\text { Strongly } \\
\text { Agree }\end{array}$ \\
\hline $\begin{array}{l}\text { Participated in a Transition } \\
\text { Assistance Program (TAP) } \\
\text { class in the military. }\end{array}$ & $\square$ & $\square$ & 口 & 口 & 口 \\
\hline $\begin{array}{l}\text { Met with a Military Education } \\
\text { Specialist in the military to } \\
\text { discuss choosing a college or } \\
\text { degree program. }\end{array}$ & $\square$ & $\square$ & $\square$ & $\square$ & $\square$ \\
\hline $\begin{array}{l}\text { Met with a counselor to discuss } \\
\text { financial planning which includes } \\
\text { G.I. Bill benefits. }\end{array}$ & $\square$ & $\square$ & $\square$ & $\square$ & $\square$ \\
\hline $\begin{array}{l}\text { Ordered transcripts from } \\
\text { military courses and training. }\end{array}$ & $\square$ & $\square$ & $\square$ & 口 & $\square$ \\
\hline $\begin{array}{l}\text { Applied to colleges and universities } \\
\text { as soon as possible. }\end{array}$ & $\square$ & $\square$ & $\square$ & 口 & $\square$ \\
\hline $\begin{array}{l}\text { Discussed the civilian workforce } \\
\text { with a career counselor. }\end{array}$ & $\square$ & 口 & $\square$ & $\square$ & $\square$ \\
\hline
\end{tabular}

Q29 Please indicate the time frame between discharge from military service and starting college classes.
1-2 Weeks
- 3-4 Weeks
口 1 Month
口 6 Weeks
口 2 Months
口 3 Months
- 4-6 Months
ㄱ-12 Months
口 1 Year
- 2 Years or more
- Still in the military and taking classes.
Other (please specify) 
Q30 Please indicate your student status.

a Freshman

- Sophomore

a Junior

口 Senior

- Graduate Student - Master's Program

G Graduate Student - Doctoral Program

$\square$ Other (please specify)

Q31 I'm attending this university / college as a...

Part time student

G Full time student

$\square$ Other (please specify)

Q32 Please indicate your major or program of study.

Q33 How many times have you missed a class during the Spring 2014 semester?

a Attend all

a Missed 1-2

․ Missed 3-4

口 Missed 5-6

Dropped the course

$\square$ Other (please specify)

Q34 Please indicate the number of credit hours you have completed toward your degree so far.

口 $0-24$

口 25-59

口 60-89

口 90 hours or more

- Graduating this semester

$\square$ Other (please specify) 
Q35 What is your current military status?

Active Military

$\square$ Veteran

r Reservist

- National Guard

$\square$ Other (please specify)

Q36 What profession or specific career path do you intend to enter after graduation?

Q37 What do you think you will be doing during the 2014 Fall semester?

Taking classes at this University / College

$\square$ Attending another University / College

- Taking time off from school

Employed - no longer taking college courses

D Deployed

$\square$ Other

Q38 What VA Education Benefits do you qualify for?

Chapter 30 Montgomery GI Bill Active Duty

- Chapter 31 Vocational Rehabilitation and Employment

口 Chapter 33 Post-9/11 GI Bill Active Duty

- Chapter 1606 Montgomery GI Bill Selected Reserve

口 Chapter 1607 Reserve Educational Assistance Program (REAP)

None of the Above

$\square$ Other

Q39 After graduation I plan a career in:

$\square$ the U.S. Armed Forces

$\square$ the Civilian Workforce

Undecided

$\square$ Other 
Q40 My coursework is conducted primarily...

In the Classroom

a Hybrid - Classroom and Online

口 Online

口 Virtual

Webinar

$\square$ Other

Q41 What is your GPA?

口 1.5

口 2.0

口 2.5

口 3.0

口 3.5

口 4.0

$\square$ Other (please specify)

Q42 Do you have any children?

Y Yes

O No

Q43 Is there anything else you would like to share about your experiences at a Military Friendly University / College?

Q44 What is your age?

O 18 to 24 years

25 to 34 years

O 35 to 44 years

O 45 to 54 years

O 55 to 64 years

O 65 years and over 
Q45 What is your race?

White

$\square$ Black

口 Hispanic

- Asian

․ Native American

$\square$ Mexican

口 Pacific Islander

- Multi-racial (please specify)

$\square$ Other (please specify)

Q46 What is your gender?

O Female

O Male

Q47 Please indicate your marital status:

O Single

O Married

O Separated

O Divorced

O Widowed

O Never Married 
Q48 In which state are you currently enrolled in college courses?
O Alabama
O Alaska
O Arizona
O Arkansas
California
O Colorado
O Connecticut
O Delaware
O Florida
O Georgia
O Hawaii
O Idaho
O Illinois
O Indiana
O Iowa
O Kansas
O Kentucky
O Louisiana
O Maine
O Maryland
O Massachusetts
O Michigan
O Minnesota
O Mississippi
O Missouri
O Montana
O Nebraska
O Nevada
O New Hampshire
O New Jersey
O New Mexico
O New York
O North Carolina
O North Dakota
O Ohio
O Oklahoma
O Oregon
O Pennsylvania
O Rhode Island
O South Carolina
O South Dakota
O Tennessee 

O Texas
O Utah
O Vermont
O Virginia
O Washington
O West Virginia
O Wisconsin
O Wyoming 


\title{
APPENDIX B
}

Students' Perceptions of Resources/Services/Programs Needed

\author{
Priority Registration \\ Lounge \\ Priority registration \\ Veterans' Lounge \\ It needs to pair and incoming veteran with an upper class veteran to help navigate through all \\ of the things that a student needs to know. \\ Veterans Lounge, Priority Registration \\ everything you listed that I did not check \\ more parking spaces \\ Would Like To See A Student Veterans Of America chapter \\ Priority Registration \\ more events specifically for Military members and veterans to help us meet and form a \\ community with one another \\ in state tuition is my biggest disadvantage \\ priority course registration \\ faculty and staff classes to better assist the military \\ Not to my knowledge \\ MILITARY LOUNGE \\ bookstore at Erma Byrd Center \\ help with PTSD / school advocate \\ A better system for processing VA education benefits. \\ Separate orientation \\ Each campus should have a veterans rep of some kind \\ Tutoring for vets \\ Ability to identify and report students and faculty that discriminate against veterans \\ Veteran tuition rate as in other institutions ie Northern Arizona University \\ Something more hands on at the actual Tucson Component location instead of having to go to \\ another University location \\ Disabled Vet liaison \\ Tuition Assistance for Veterans \\ My school may offer all of these services but I don't know about them. A simple, brief \\ handout listing available resources would be great. One that can be scanned during a busy day \\ as opposed to a website that you have to learn to navigate. College keeps one busy and the \\ less time wasted is better. \\ I would like to have an advocate available to assist with GI Bill issues. The VFW and DAV \\ are not helpful for GI Bill issues \\ appropriate housing at all campuses \\ Mentoring program with faculty mentioned above
}


the buddy system indicated above

knowing other veterans in my classes

job oriented things, put people to work as they are going to school

Better understanding of military education

Veteran Housing

priority registration

college credit for military training

My college does not accept AARTS transcripts of any kind so I am down 9 credits since I

transferred

They offer more assistance to undergrad students than grad students. They should offer services geared for military grad students as well.

VA center on Polytechnic campus of ASU instead of just the main Tempe campus

Yes, we should be able to transfer credits from military service to college

A center at each campus

I don't know what's in the planning stages

better awareness to veterans of services offered

COLLEGE CREDIT FOR SMART TRANSCRIPT COURSES

Assist first semester veteran students

Discounted or free year gym membership for Veterans at the school

Mentors and Jobs for Veterans

college credit for military service/experience

I would like to see academic advisors who work solely with veterans. The current system makes it difficult to transfer SMART credits in a timely manner. A dedicated advisor could quickly break down transfer credits based on rate and training received. It would also be nice to have someone fight for credits so the student vet doesn't have to. We have fought enough already.

More veteran friendly services

ASU Online Social Network exclusively for Veteran Students \& Alumni

Help with yellow ribbon program and other important deadlines

ORIENTATION

better trained military advisors for benefits

unknown

One-stop center

Separate area used for decompression

greater veterans program awareness

social area for veterans

participation and cooperation with local military bases and resources

More than 1 primary online military specialist

need more tutoring for $\mathrm{mct}$ campus

I would like to see more support for veterans using the GI Bill and receiving MHA.

I think it would be very helpful if there was some kind of partnership between student health and the VA medical center so that veterans that have service connected disabilities that require physical therapy or chiropractic be seen on campus. I think it would save a lot of gas and travel time for student veterans.

I can't think of any at this time. 


\begin{abstract}
APPENDIX C
Students' Expectations of a Military Friendly School
\end{abstract}

Accommodating. The school should realize that active/res members and veterans have much more complexity in their lives. As such, there should be an added level of respect and accommodation given for those pursuing higher education. The budget for the veterans' admin facilities should reflect this respect and appreciation, as should the support provided (\# of personnel, breadth of resources, etc.). Specifically, there should AT LEAST be: Veteranspecific tutoring / mentorship / career services / advising; Veterans priority ("free") access to games, conferences, events, etc.; a Veterans' lounge and learning center; Veterans housing and shuttle service.

A facility that seeks every way to help and pay honor to those who have served.

All of my expectations are met. On campus VA representation to handle all my VA paperwork, priority registration is a bonus, and my adviser/employer has been very accommodating to my Reserve duty.

Allowing in-state tuition for those moving to the area. Giving opportunity to get together with other veterans if you'd like to. Recognizing that you are on a different level than the "regular" students.

A Military Friendly University/College in my eyes is willing to understand that military members have special concerns unlike those of civilians and is willing to understand if we must tend to the call to serve by helping us to put our college career on hold with the least amount of complications possible and welcomes us back when our mission is over. They are also willing to provide us credit for the courses we earned while serving in the military and are not rude to us when it might take us a little longer to transition back into civilian life. A Military Friendly University/College should also be sure that each instructor be aware and considerate of those in their class who are military members or veterans so that they can be aware of the fact that they may have certain obligations to fulfill for their military branch that may interfere with class.

A military friendly university provides all necessary information to use benefits, allows for early enrollment into classes to finish coursework under benefits, has tuition exemptions after GI benefits have expired. 
Any university or college that is proactive in making contact with veterans. They need to do one on one counseling to explain the admissions, registration, and benefits process. They need to accurately and speedily process paperwork and get it sent to the VA. Failure to check accuracy and process paperwork in a timely manner directly affect veteran students financially.

\section{Arizona State University}

A school that does not give too much preferential treatment to veterans aside from minor things like priority registration.

A school that has a one stop shop solely dedicated to its veterans. Having its own academic counselors that specialize with veterans and help them with their transition through school. help them pick out the best classes for their future. The counselors now does not know how overwhelming it is for soldiers used to having supervisors or administrator shops guiding them every step of the way, then to come to college where everything is automated. Soldiers are built and trained for face to face instruction, not automation.

I'm tired of academic counselors doing the minimum during my meets with them and just expect me to know what I'm doing and pick all of my classes.

I want to see a one stop shop where a Standing Operating Procedure is in effect. Station\#1 inprocessing Station\#2 Benefits check Station\#3 academic counselor/input class selection Station\#5 submit VA paperwork Station\#6 Validation, paperwork double check.

A school that has a veterans affairs office and flexible towards student veterans.

As for me, it does not meet my expectations. All of the services are located in the Tempe (Main) campus, and counselors are only available in the other campuses two days a week for any questions regarding education benefits. A veteran's lounge would be appreciated as well, my junior college had a wonderful setup for the veterans.

ASU is friendly for vets but only if you go to the main campus and if you pay to be a part of the Student Veterans club we must pay fees. Tuition is already high enough, joining a club that has an enrollment fee is not really what I am looking for.

Assistance in loans, grants, programs, etc. - When I started school, I looked for these resources and they were non-existent, so I had to figure things out on my own. It's taken me longer and cost me more to achieve my goals, while I know I could have been further along with less debt.

ASU has been fantastic and meets my needs very well 
ASU has exceeded my expectation. The Tillman Veterans Center has taken all the worry away from registration and receiving benefits. From the in state tuition to the early registration has assisted me in my pursuit of my under graduate degree.

A university that does not focus on lip service towards veterans by only offering free tickets to sport events but one that recognizes veterans for their previous accomplishments and not treated disrespectfully and with disdain by the faculty.

A University that strives to work with/around and accept college credit earned during service and training.

A university with faculty members that understand that military students have military obligations.

Awards college credit for courses taken during military service and training.

Concord University

Degrees available through on-online courses that are equivalent to on campus students. Also ease of enrollment for Veterans and understanding of situations when it comes to National Guard or Reserve status when it comes to deadlines.

Department recognizes my military service as significant. I should not have had to show leadership or service for a certain program requirement. I think that my four years of active duty service should have counted.

Easy access, VA center, some benefits like free parking? Or military discounts on things that GI BILL doesn't cover.

Easy and friendly

Ensuring each Veteran Is Assisted With Every process. Club for Only veterans. Tutoring For Classes For Only Veterans By Veterans.

Everyone would help them in ways to help them get through college after been around the world and not in school after 20 years... be more sufficient in regards to helping vets.

Flexibility for travel/deployment

Give some credit for technical military training and experience.

good

Good

Has a military clause/handbook that clearly states what happens if you miss class for deployments/training/etc...

Having a Veterans Services office and staff who are experienced with VA Education information and can communicate well with Veterans. 
Having priority registration, having a transition program that addresses the differences of being an older, often more mature student than the regular incoming student. Also, having an understanding that recent military service often brings with it a variety of mental health issues and these have impact on being a student, but that should not reflect poorly on the student.

Having staff that is competent in understanding how to process military educational programs.

I actually do not know. I was trained to adapt to circumstance and so, I did.

I don't have any particular expectations. ASU policy already has help for veterans through the main campus and everyone on both campuses does their best to help with military and disabled students. Because it's a new campus it is still very small and personal - so each student's issues are addressed on an individual basis by faculty and staff. Because there are no plans to make it a full size university campus I think ASU Havasu will remain a great campus for military and disabled students, because there will always be more one-on-one time with faculty and staff.

I don't know, I think all the schools are bending backwards for veterans because the job market sucks right now and they are headed to college and they are fighting to make them come to their school.

I don't know what it means to be "military friendly." A school that treats all students the same would be ideal. Nobody deserves special treatment.

I don't really have a lot of needs. I just need my GI Bill to be processed so that I can focus on getting good grades. I like that I never have to worry about paying money out of my pocket. I had an excellent experience at Concord.

I have felt supported. I haven't had paperwork issues. It has gone great.

I think the veteran's rep is top notch and has a genuine care for the veterans and military students and does everything in his power to help all the needs of military students. It will be a great loss to WVU if Jerry was to leave and does not find another rep that is as hard working and knowledgeable as Jerry is.

It is an extremely military friendly school - all of the fellow veterans I have talked to feel the same way. The support is excellent from other veterans and the staff and professors.

It's hard to say as I think of a military friendly school above and beyond the tools available would hinder in the assimilation process. It's not the schools I find difficult to be a part of, its 
self- identifying with some version of me that is not fueled for violence any longer. I think tools to help veterans understand that who they used to be is no longer who they are will be helpful, but I would imagine intense resistance to the concept. I think it's the PTSD that needs to be addressed, not the university.

It should be easy to submit GI Bill forms, and the GI Bill should cover the cost of the school. It would have family housing for veterans and other non-traditional students that isn't located only at a remote satellite campus.

I was unaware that ASU was a military friendly university. I was very disappointed and dissatisfied on the communications on how to locate these services.

I would describe a military friendly university as one that takes time to accommodate it's veterans and current service members. It needs to accept VA Benefits and understand the soldier.

I would describe a military friendly university as treating veterans just like any other group of people. As a veteran, I don't need any special treatment, and I don't believe veterans don't need to be treated special. As long as our financial needs are met through the VA, we are usually harder workers than our civilian counterparts.

I would describe it as a University that does its best to allow veterans to transition to civilian life. Veteran integration is the most important aspect.

I would expect a Military Friendly University to embrace the Veteran population and get the information on services out there!

I would want a military friendly university that has an office who can easily answer my questions regarding military forms and tuition forms.

Just helpful in all manners, even those the student doesn't think they'll need help in Location where we are accepted and not discriminated against. Faculty that are willing to work with those who have special needs.

Marshall has a long way to go to be Military Friendly. The Veterans Liaison is doing his best but the campus, faculty and staff do not seem military friendly.

More help with reminders on application deadlines through email

More obvious information about available services without having to navigate a complicated, wordy website.

Most Veterans I know don't expect much from anyone outside of our services. I was surprised to see how the folks at Marshall greeted me with open arms and went above and beyond the call to help me get back into classes after 25 years away. "Military Friendly" to me simply means having personnel on staff that understand what we've done in our military careers and 
how that's prepared us for the challenges that lie ahead of us. Maximizing the college credits allowed for our military schools is a big part of that. Having a helpful point of contact to assist us with the GI Bill paperwork is a must.

My expectations were to obtain a degree and find employment before graduation. That did happen, I never expected much from the University other than fair treatment with no bias, this also happened.

None of my expectations are/were met. The veterans' programs are all geared to young veterans who recently separated. Those of us who are older and took a more circuitous route to university life are outliers who are ignored.

Offering everything you list above would pretty much meet my personal expectations. One at which staff (e.g., grad admissions staff at the W.P. Carey School at ASU) who proactively ask prospective students whether or not they are military members, and who demonstrate a willingness to be helpful.

One that attempts to work together with the Veteran Centers to insure timely registration for classes; as well as working with the Finance office regarding tuition payments. If the payments are going to be late and deferment is necessary, it should be relayed without a lot of veteran activity because it gets confusing.

One that doesn't view you as another ATM machine like it does everyone else.

I think that it should have a lounge or a place that veterans can be among other veterans, not the ROTC lounge.

One that easily outlines steps for veterans to become adjusted to civilian/campus life and support centers that cater to their lifestyle or needs.

One that goes a step above and beyond for the Veteran students.

One that has a veterans' office, a program I am interested in, and a convenient location.

One that has the knowledge for unique circumstances. For instance, I was initially told the Post 9-11 GI Bill would not cover my tuition by a staff member in the Veterans Office. I had to research on my own to find out that was incorrect. If I would have taken their advice, I would not be four classes away from graduating now.

One that honors your service and experiences regardless of political affiliation. One that is accommodating to the military life, one that understands that military obligations come first, family second, and education third. That is not to say that veterans do not value education, but in the grand scheme of things, education has to come behind the military and 
family. Also, a military friendly university would understand that servicemen have stresses unlike those of non-service students in their lives.

One that is familiar with and works well with all types of military financing One that is knowledgeable about available benefits, capable of processing those benefits, able to coordinate with other departments within the university to address veteran-specific issues. One that provides a resource for veterans to link them together. Also one that provides career counseling and GI Bill services for newly separated veterans.

One that takes into account the unique experiences and needs if service members and their families. The transition from military life is particularly challenging. Grants for veterans to aid in supporting veterans who wish to improve themselves would go a long way.

One that understands that many veterans are attending classes on GI Bill funds which cannot always cover the cost of attendance. One with a transition program or a career counselor who can coordinate university and veterans resources to their maximum potential

One that values the military experience for what it can share with other students and helps the military person transition to the academic environment.

Overall they are doing a great job. I think a lot of the services go unused, but that is mostly dependent on the veteran. Sometimes we just want to be a civilian and sort of do as little as possible to be labeled as a veteran or relive that time in our life. Unless you're in the Marine Corps, then we're really moto.

Primarily helps with processing of VA benefits and accommodates active duty, reserve or guard duty requirements.

Priority for class enrollment, transfer of military education to college credits

Provides appropriate flexibility for deployment, financing, and processing of VA education benefits. Maintains a competent VA office with 24/7 access.

Someone I can talk to at all times and can figure out any issues that arise.

Support available for veterans especially addressing payment via GI Bill.

Supportive and sympathetic to transitioning military members.

The above services and an active and participatory administration and Veterans Club.

The best is the lounge.

The college does ok, although when registration opens they should also give priority registration to veterans and not just honors, we did serve our country. Also allow us to pay instate tuition rather than the outrageous fees of out of state, I just got out of the service in September and of course I am an out of state student. 
The military advocate is fast to respond to my questions and provides me with resources if she does not have a specific or detailed answer, there are often focus groups and surveys that veterans can take, and even veteran groups to keep veterans socialized after service.

There is a nice Pat Tillman Veteran's Center.

The Vet center is awesome. They walked me through the process of getting my benefits started step by step. My only grievance is the lack of understanding the Joint Service Transcript. I was only given eight credits out of 84 health care related credits that I should have been awarded for my Army nursing school. The staff in the college of nursing views military education as inferior.

I had to take three classes that were completely redundant.

They have a specific department for Veterans

They have met my standards to a satisfactory level. My college claims to be the most military friendly, but when dealing with certain matters the experience leaves me feeling far from a friendly environment.

They haven't really done anything for me. Then again, I don't rely on my Military experience for anything.

This would be a college in which it was safe and comfortable for members to walk the campus in uniform. The college should also have some place where students using Vet benefits can ask advisory questions about their classes (rather than asking a civilian campus advisor who usually isn't knowledgeable about Vet needs and limitations of benefits). There would also be an office or at least one person to assist with disability claims which are time-sensitive but very difficult to take care of when you are also a full-time student.

Useful and helpful for those in reserve or national guard students

Veteran friendly campus and knowledgeable about the different tuition assistance available for military members.

Well-staffed and friendly VA office.

Better system set up for students who want to study abroad. Difficult and confusing. Willing to work with service members.

WVU has been wonderful. In fact, far beyond what I expected.

WVU seems fine.

Yellow Ribbon Program / Veteran's Councilor in Registrar 


\section{APPENDIX D}

Students' GPA

3.94
3.9

3.9
3.9
3.9
3.87
3.85
3.85
3.84
3.8
3.8
3.8
3.78
3.75
3.75
3.75
3.8 to
3.75
3.7
3.7
3.69
3.67
3.65
3.61
3.6
3.43
3.4
3.4
3.3
3.25
3.14
2.8
1.83




\section{APPENDIX E}

Students' Majors / Plan of Study

(English) Linguistics with TESOL certification

Accountancy

Aeronautical Management

Applied Biological Sciences

B.A. in history, B.A. in Religious studies

B.S. Economics, minor in Math

B.S. Nursing

B.S. Political Science

BA History Minor Justice Studies

Biology

Biology

BS Chemistry

BS Geography

BS Sustainability

Business

Business

Business admin.

Business Administration

Business communication

Chemistry

CIS

Computer Engineering

Crime, Law, and Justice

Criminal Justice

criminal justice

Cultural Anthropology

Curriculum and Instruction Ed D

Doctor of Business Administration

Economics

Economics

Ed

Education

Electrical Engineering

Electrical Engineering

Elementary Education

Engineering

English awaiting assessment and transfer to journalism program

Environmental Geoscience

Environmental Science 
Environmental Technology Management (BS)

Exercise and Wellness

Exercise and Wellness

Film

Film

Filmmaking Practices

Global Studies BA

Hispanic Linguistics

History

History

History

History

International Letters and Cultures

International Relations

International Studies

journalism

Kinesiology

Law

Library Science / Anthropology

M.S. Integrated Marketing Communications

Master of Social Work, Master of Public Administration

Masters of Architecture / MS Built Environment

Masters of Architecture and Masters of Science of the Built Environment

Material Science Engineering

Matg

MBA

MBA

mechanical engineering

Mechanical Engineering

Mechanical Engineering

Mechanical Engineering

Media Studies

Medical Laboratory Science

MHS- Pathologists' Assistant

MIS

Molecular Biology and Biotechnology

Nonprofit management and leadership, pre-physician's assistant

Nursing

Petroleum Engineering

Physical Education Teaching Education

Political Science

Political Science

Political Science/Pre-Law

Pre-Med

Psychology

Psychology 
Psychology

Public Affairs

RBA

RBA

Regents BA

Regents Bachelor of Arts (RBA)

Russian BA

Secondary Education: Earth and Space Sciences

Social and Behavioral Sciences

Social Work

Social Work

Social Work

Social Work

Social Work with an emphasis in clinical counseling and behavioral health

Supply chain management

Website Design/Web Development 


\section{APPENDIX F}

\section{Student Service Members' and Student Veterans’ Professional Objectives}

Academic, Ph.D. Program in Criminal Justice

Active duty

Airline Management

Anything I can get in this economy.

Architect

Archivist, Curator, Librarian

Auditor in public accounting firm

Business Administrative

Business Management or Consulting

Business Owner, Manager, entrepreneur,

Business side of the movie and TV industry.

Chemist

Civilian nurse and commission as an Army Reserve into the Nurse Corps

Clinical Psychology

COMMISSION

Commissioned Officer

Congressmen

Continue and further career within the VA medical system

Continue military service

Counselor

Cultural Anthropologist

Economist

Either Architect or Building Energy Analyst, leaning toward energy analyst

Electrical Engineer

Electrical Engineering

Engineer

Engineer

Engineering

Engineering

Entrepreneur

Entrepreneur, looking toward manufacturing and small tech

Environmental health and Safety Office

Environmental Sciences

Environmental

Federal Government

Federal Service 


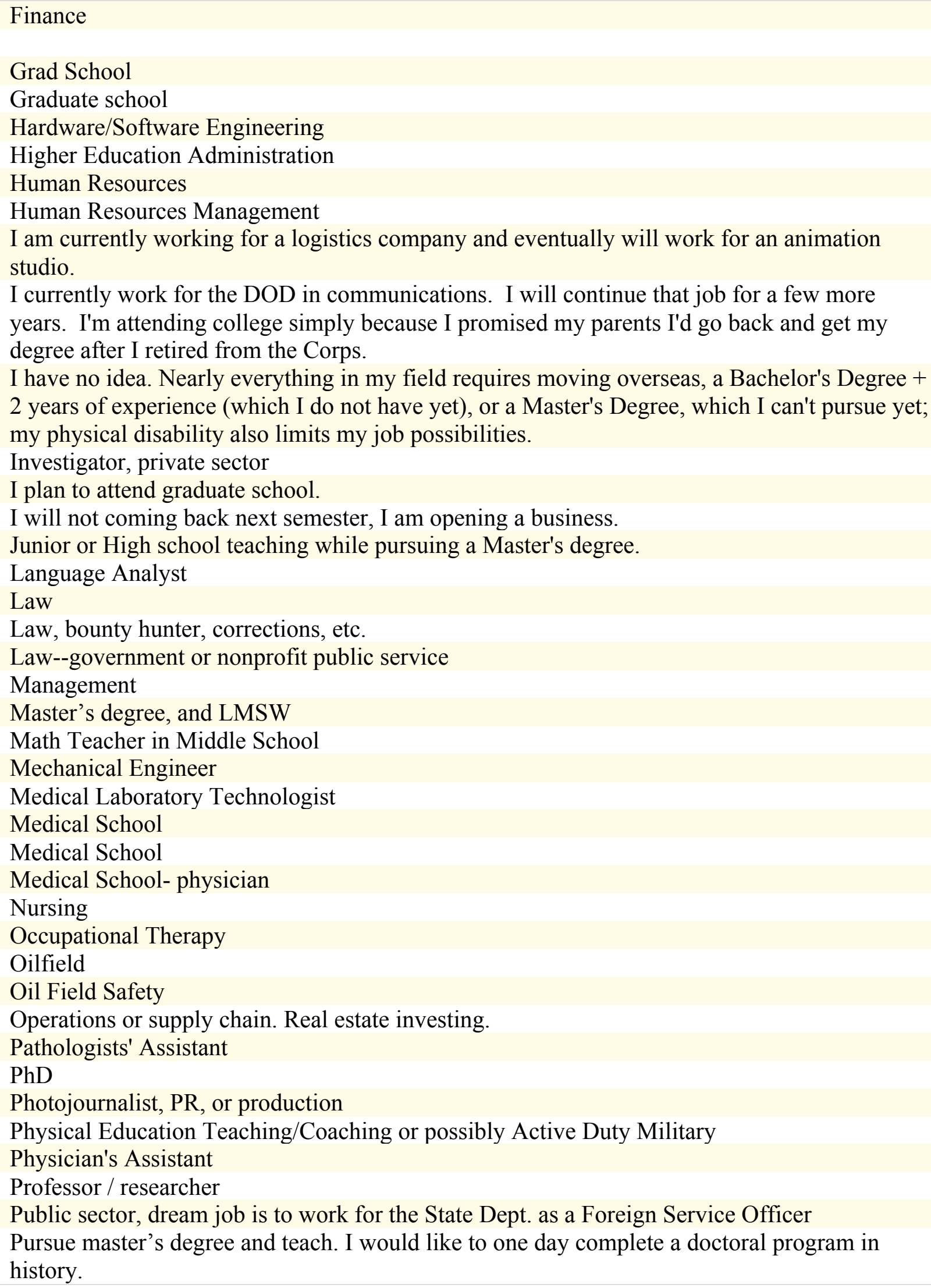


Researcher, Academics, Writer

Research science

Safety Management

Social Services

Social Work

Social work/Civil Service

Social Work with a specialization in Drug and Alcohol addiction

Sound Technician

Sports Performance

State Department

Strength and Conditioning Coach/Football Coach

Supply Chain Management

Supply manager

Systems Administrator

Teacher

Teacher

Teach history

Teaching

Teaching/management

Teaching and Coaching

Teaching high school

Undecided

Water resources

Web development career

Working with women particularly, female veterans diagnosed with PTSD and other related mental health problems due to MST and or any other related trauma. 


\section{APPENDIX G}

\section{Failure Is Not The Option}

Survey Question \#10

Please describe why you may fail to complete your education at this university / college and not graduate with your degree.

I will not fail.

I will not fail and graduate in December 2014.

Due to holds on my account with financial aid and military advocates not communicating Excessive out of class requirements such as papers and redundant readings to fill time. Myself is the only thing that will keep me from getting a degree.

The only reason that I may not complete my academic goals at WVU is if we move away. N/A

I will graduate this summer. If anything stopped me from that it would be family reasons. I will not fail.

$\mathrm{n} / \mathrm{a}$

No explanation. Failure has never entered my mind.

$\mathrm{N} / \mathrm{a}$

It would require extraordinary circumstances for me to not complete my education here.

\section{N/A}

I will graduate?

I'm not going to fail. I'm graduating this May and have met all requirements and am graduating with honors.

$\mathrm{n} / \mathrm{a}$

I won't fail.

I will not fail. 
I can't see me failing at Marshall. The people there have bent over backwards to ensure my success.

Personal issues/ money.

courses not offered year round

N/A

only if a better opportunity presented itself

Won't

TBI issues

Life happens. I started at concord as a single man working a part-time job. Now, 6 years later, I am married with 2 children and a full-time job. If I was not committed and/or pushed to complete by my family I probably would not have completed my education.

I will not fail.

Being an older vet, 20 years older than most of my classmates, most classes seemed geared toward traditional students, not much online for those of us that work full time and have families. Also, feel lost sometimes and not really having a buddy system to help lead the way or at least point in the right direction stinks. Feels like falling through the cracks sometimes:( Doctoral program offers limited support, guidance, and clarification for dissertation and doctoral study requirements.

none

I won't

It would be my fault

I simply get lazy because the work is sometimes too hard and I don't want to put the effort in. That failure is mine and mine alone.

I expect to continue to be frustrated by grad admissions staff at the W.P. Carey School at ASU, to the point where I will just enroll elsewhere to complete my degree.

If I need to move for work.

Anything is possible

I am diagnosed with PTSD and depression. Both of these impact social engagement and group work in general. These also impact my short term memory which makes long tests and exams difficult and more stressful.

Doesn't apply to me. I am on track to graduate in May 2015. 
I will not fail

Funds from GI bill and Vocation Rehab running out

N/A

If the GI bill runs out or if they were to ever stop the BAH I would not be able to attend school.

Due to one faculty member with a personal grudge against me. I am doing all that I can in the course, even requesting an extension after being told a medical excuse is not an excuse by this faculty member. He may by his own judgement force me to wait another year to retake this course with another instructor.

Lack of resources

Having already encountered and dealt with one professor who has a virulent anti-military philosophy and bias against veteran students; should I encounter more, I may reconsider my choice to attend Arizona State University.

I wont fail.

No reason

I think the biggest challenge for me is trying to balance my home life and my school work. I always take a rather heavy course load and it can sometimes affect the time I have to spend with love ones.

Time

Non-applicable

N/A I graduate next week.

I have encountered a problem with one of the professors at this university because of the absences accrued from being in the military. I had several military obligations and training dates that I had to attend to, and when I attended them (it was about two weeks or two and a half weeks, separated), one of the professors would not let me make up the absences and he told me to withdraw from the course. I felt that it was unfair because I had no control over this. The course I had to withdraw from was a course I needed to graduate this semester. Because I had to withdraw this semester, I have to take another semester in the fall. This is unfair.

I won't fail to complete my education.

N/A 
None.

Decided to move out of the area for family reasons.

The only reason I might choose not to complete my chosen degree program here is because they haven't accepted many of my transfer credits received during military training, and I might be able to graduate sooner at a different University. I will not fail to complete my college education at the college unless my husband, who is active duty military as well, has to PCS prior to completion.

$\mathrm{N} / \mathrm{A}$

If the money runs out before I get my degree

Not applicable.

$\mathrm{n} / \mathrm{a}$

The difficulty of some of the course work and the lack of tutoring. Don't mistake me, my campus has a few free tutoring centers and I have made great use of them. Rather, I mean to say that many students returning to college from the military are older and have been out of high school much longer than the rest of the student body. This means we have MUCH more brushing up to do on academic skills that have likely gotten rusty during our time in the service. Tutoring centers on campus can get very busy and I have waited for 45 minutes for a tutor on several occasions and as I said above, some of my skills have rusted considerably in the 25 years since I was in high school. Proceeding on without some assistance is often not an option. I would love to see either a veteran's tutoring center or more financial access to personal tutors than is currently available.

the only problem I foresee in not completing my education would be lack of funding $\mathrm{n} / \mathrm{a}$

I won't fail.

If anything it would only slow me down, but I just got hired on at social security full time, part of the reason I was even considered without a degree is because I'm a veteran.

I won't. But in reality being a military friendly school has nothing to do with a student's success, that is all based on the student.

Length of time and having necessary funds to continue.

It would have to be severe financial or family problems to stop me.

Won't happen :) 
My failure would not be due to anything veteran related outside of the issue of being surrounded by high schoolers with no life experience who snivel and whine while spending their parents' money at the university to party and skate through life.

I Struggle With The Mathematics Due To Not Attending School For So Long And Struggle To Find The Help I Need.

No reason, I am graduating.

I don't understand this question.

I will graduate.

Nothing will stop me.

Full time employment in a field I enjoy would take me away from school.

At first, it would have been due to my assimilating back into zones with a dense population but I learned to face my personal challenges head on and am graduating next week.

I just finished my program.

No direction or guidance to choose the right classes within my degree program. I literally guessed for some of them, I am just lucky I guessed correctly.

If I get a job that requires me to move to another state or country coma

I must work full time and take a full graduate program load and it is very demanding in time. $\mathrm{N} / \mathrm{A}$

No reason

Financial ability and working full-time to pay for life!

If something crazy happened that kept my wife from working or required me to work fulltime. Maybe a large medical issue or expense?

N/A

Financial reasons could cause me to fail completion of my degree.

I am mobilized with my reserve unit which disrupts my degree program.

Being busy with my family

Not enough networking between veterans. Also professors don't understand what it means to be in the service or a veteran. We're not normal students who are 18 years old straight out of high school and all we have time for is school and party. Many times we have deadlines for 
many other things that get in the middle of school. Even though we inform the professors they seem to not care and give a failing grade anyways instead of collaborating to help us pass the class or semester.

Unsure.

I will complete my degree.

Work/Life/Family/School Balance

Because I am a head injury survivor with some physical and mental issues, the curriculum itself may be more than I can manage. However, if I fail it won't be for lack of trying with everything I have - and the faculty and staff are all aware of my determination and have said they will provide any assistance they can to help me. They have already proven their willingness over the school year I just completed. I don't think if it was at a "full-size" campus, such as the main campus at Tempe, I would be able to do as well as I have.

If I get my dream job before the time I graduate.

Insufficient GI Bill funding 


\section{APPENDIX H}

\section{Defining Camaraderie}

Survey Question \# 17 How would you describe to a civilian what camaraderie is as it relates to military members and veterans on campus?

A bond between military veterans and members.

A Comfort. Sharing An understanding And having common Goals.

A great supportive system.

Always having each other's back - if the person needs anything you try to assist as much as possible.

An adaptation of an attitude reflecting shared collective goals and implicit trust and teamwork. An investment of trust and reliability for individuals you don't yet know and a bond of friendship and empathy for those you do, garnered by the knowledge of shared experience, training, and ethics.

Any Marine is a brother or sister; anyone else is a close cousin...! Just kidding. Honestly I would say that camaraderie exists because military service members share common experiences. A real feeling of care for that individual and wanting to help them be successful in all they set out to do, it's a brotherhood and sisterhood of the finest America has to offer! Never leave a soldier behind!

A shared experience that only military members can understand.

Basically having each other's back at all times and focusing on meeting the goals together instead of competition.

Being able to help one another when in need.

Being there for each other no matter what, a brotherhood.

Brotherhood

Brotherhood

Brotherhood

CAMARADERIE is a brother/sister-hood that comes from similar experiences.

Camaraderie is a way of sharing a special bond because the people have gone through similar training/experiences and by having that in common you bond. The bond is so strong that those who you share similar training/experiences get your way of thinking and become a part of your 
family. A family that is not related in blood or by titles but a family that you would be willing to defend with all your might in times of need.

Camaraderie is bond that cannot be broken between people who can know what it means to sign a military contract and deploy in support of the United States.

Camaraderie is the unspoken bond that many military members share due to similar experiences in their lives.

Camaraderie is very much akin to family

Camaraderie of the military can be equated to the bond between fraternity brothers. However, this bond is stronger due to the nature of what a person encounters in the military. You never had to have met another military person to care about them, especially if they were in the same branch. There is an instant connection when you meet another member/veteran for the first time. Common bond that is unspoken.

Events where we can get together and network and share stories from deployments.

Experience in the military changes people...often for the better.

Feeling that you can trust your life with your battle buddies and having experiences that prove it. For a civilian it's pretty much how you feel about your blood family. You love them to death and would do anything for them. But their friends not so much maybe sometimes and acquaintances they wouldn't do anything. For veterans it's different if we know another veteran from the past you have a really strong trust and love for that person. If you just meet another veteran you show respect and enthusiasm all the time.

Friendly conversation simply.

Friendship, understanding, and a general shared past experience.

Friendship and a shared understanding

Going through the same training as other military members. Share a special bond.

GOOD

Good

Great

Highest-level responsible friendship.

I'm not on campus....But Camaraderie between veterans is strong in any environment. It's difficult to relate to someone who hasn't shared the same experiences that you have.

I don't experience military camaraderie on campus. I would be open to it though.

I don't know.

I don't think I will ever share the camaraderie that I experienced in the Marines.

I do not feel any camaraderie with military members or veterans on campus, just as I did not feel it while I was serving, but I would try to describe it to a civilian simply by saying that sometimes veterans and current military members feel a closeness to one another because of shared experiences that the average civilian will never understand.

I do not know what camaraderie is.

I feel no camaraderie towards other veterans on campus.

I have no camaraderie with other veterans on this campus. 
I have not met any members who have served or are currently serving.

In theory, I would tell a civilian student that our camaraderie comes from a similar past and, therefore, similar challenges in the present. HOWEVER, as a whole, the veterans on this campus are not a very tight group.

I really don't have camaraderie with anyone on campus because I don't know anyone else on campus who is a military member or veteran. The camaraderie I share is with my brothers and sisters in arms who are spread throughout the country and the world, and we talk to each other on a weekly basis. We encourage one another to press on towards our goals and are always there for each other in the good times and the bad, no matter how far apart we may be. Camaraderie I believe is a hard thing to explain to people who have never had the pleasure of experiencing it. It's about cohesiveness and working with others despite your differences.

It's an issue of trust, that each member instinctively knows that the other will do their part, and come through no matter how difficult the project or task. I will not be left "hanging dry." My best group projects have all had other service members in them, the only problems with individuals not applying an effort or completing their assigned part of the project has come from young civilian students.

It can be indicated by the close association many ROTC, Vet, and military members share while on campus. It is visible in that other than rushing to classes, students in uniform are usually walking and socializing with other uniformed members (or people wearing obvious promilitary/vet marked clothing).

It is a commonality of backgrounds and experiences that creates a bond between individuals.

It is an everlasting bond that allows us to think as a collective - taking care of one another as we realize we have been through trials no fraternity could ever experience nor amount to.

It is a shared understanding that we have volunteered to fight for our country and in doing so share a bond.

It is like a brother and sister

It is like having brothers and sisters wherever $\mathrm{u}$ go.

It is something based on a shared experience and knowledge that is unique to a small population. Because of these attributes we have a connection that others do not have.

It is when one looks out for the other.

It's a profound understanding based on shared hardships.

It should mean that as veterans and military members, we have each other's backs. We support each other, encourage each other, and inspire each other. I'm not suggesting this doesn't exist on my campus. I'm only saying it's been a bit difficult for me to find and I feel a bit of disconnect with my veteran community.

I would describe camaraderie as having your back no matter what.

I would describe it as an inherent bond due to past experiences.

I would die for that person.

I wouldn't.

I wouldn't bother. 
I wouldn't describe it to a "civilian" as I am a "civilian" now as well. There's no need to continually discuss that I am a veteran and about my military service. Plus, "civilians" wouldn't understand what it's like to serve in the military.

I wouldn't even try.

I wouldn't really. I don't feel much Camaraderie on campus, but mostly because I choose not to. I prefer to do things on my own.

I would say that camaraderie is an essential effort made from military veterans to acknowledge how each other's service is appreciated and identify how their life has been impacted. Its knowing that you can relate to someone you may not know because they share a common mentality towards service.

Just having someone that has experienced the same things as you. When you talk to someone in the military they just understand things that you are talking about.

Knowing the lingo and learning the routine.

Military, Veterans, and any government affiliates helping and serving one another; with moral and welfare being of paramount importance.

Most don't know I am a veteran so camaraderie is standard between classmates.

$\mathrm{n} / \mathrm{a}$

$\mathrm{N} / \mathrm{A}$

Never leave a fallen comrade

Not sure no one has ever asked.

On active duty or in the national guard, camaraderie is built through shared tough experiences. It forces you to look past the things about people that drive you crazy, because you have a deeper bond forged through difficult times.

One cannot. They do not understand.

People being comfortable in having some sort of common background with each other.

Encouraging each other in a way that siblings would. Competing in a friendly manner, giving someone a hard time by teasing them or messing with them but in a way that they know comes from you caring and actually liking them.

Probably just being friends as a result of shared experiences.

Professional relationships that bolster performance positively.

Root word Comrade, which is ironically Russian for a Companion type. Someone you can trust, someone you can count on.

Shared experience of sacrifice that engenders a more implicit trust.

Shared experiences and beliefs. Always some sort of bond.

Shared experiences.

Shared experiences that civilians are incapable of understanding.

Sharing a common background or life changing experience.

Simply a common background and experience however, with the added detail of the experience and background being very unique. 
Support for each other through mutual respect and a willingness to lend a hand whenever it is needed. Backing each other.

Team work.

That is hard to say when I don't have it.

There is an instant sense of trust between members of the military. I know that I have someone I can call no matter what.

There is no accurate description of military camaraderie. As far as camaraderie on campus, I share a bond with the other Marines on campus through a shared experience and history. But in my first semester the president of the student veterans association and I did not see eye to eye, he felt very privileged and entitled just based on military service, and that has soured me to other interactions.

There is nothing like the feeling of knowing that you don't have to defend your actions, thoughts or beliefs, because the person you are talking to already shares similar qualities. It's the freedom to be yourself and let down your guard and put away your mask for a moment and vent to someone who you know has shared the same rough times and sacrifices.

This is school. Not the Marine Corps... I do not feel that camaraderie applies to school so I could not describe it in this context. Its apples and oranges. Furthermore I feel that to even ask this is ridiculous.

To keep us strong due to the things that we have all been through and seen!!!! Understanding and acceptance based on a shared past experience.

We're all brothers that share a deep bond and understanding with each other. We have a common bond kind of like a family. It is very close to a fraternity. Went to the satellite facility and did not interact with many other veterans.

Wouldn't try to explain it.

You can't. 


\section{APPENDIX I}

Additional Student Perceptions about Military Friendly Schools /College Experience Survey Question \# 43

Is there anything else you would like to share about your experiences at a Military Friendly University / College?

Arizona state university should not be considered military friendly based solely on the fact that they do not offer some credit for highly technical coursework/experience performed during service. (advanced electronics, nuclear power school, etc.) For example, I should have credit for heat transfer if I have the knowledge to help students with their heat transfer coursework.

As long as a college doesn't treat us negatively as veterans, everything else is just a bonus. I don't expect special treatment, but it is nice when they make some exceptions in cases where we differ greatly from the general student population.

ASU has a long way to go to earn the title of Military Friendly. ASU has been very helpful, especially the Polytechnic campus. been overseas

Colleges seem to be trying to wade into PTSD and emotional support for veterans. I don't think it is their responsibility to bring it up and I think too many veterans use it as a crutch while they do bad in classes. The post $9 / 11$ bill is more than sufficient for a single veteran to attend class and perform adequately well as long as they don't slack off.

Concord is a good University. They will help you with everything you need, especially Lisa Spencer.

Flexibility, particularly on the part of professors was outstanding!

Has been great so far.

Have classes that will help us in learning quicker since not been in college that are credited to graduate.

I'm on active-duty and I'm participating in the online program. So, a lot of this does not apply to my situation. This is why some answers are left blank or marked as "neither agree or disagree."

I've enjoyed the Military Campus Program. However, my university completely revamped their program the semester after I started classes. I much preferred the 10 week, once a week classes versus the current 8 week, twice a week classes. They also stopped offering as many 
on campus classes, so it has been much more difficult to qualify for on campus MHA (BAH). This is a severe problem, since I can't afford to live in my high cost of living area without the full on campus MHA. The university has ignored students' complaints and concerns regarding how the very limited on campus options affects their VA benefits (in fact, they've told us it's an improvement since we can take 58 -week terms instead of 410 -week terms a year, but really, the 8 week terms are just way too rushed).

I believe there to be a false representation of the bond that is shared between veterans, and the support that coincides with this bond. There are many veterans out there who are not proud of what they have done, and just want to move on with their lives. Most veterans I have encountered have this self- entitled attitude that makes me embarrassed to call myself a veteran.

I don't talk much about my military experience unless asked. I'm not here to make friends or socialize I'm here to work for my degree.

I do not take part in the events and organizations offered to veterans at this university. That is not the University's fault. I had just been out of the military so long when I returned to college I did not feel the same connection those immediately out of the military have.

I do not understand what the difference between a "Military Friendly University" and a nonfriendly university is. In fact, I don't know if there exists a Military Enemy University, or Military Indifferent University. A definition might help. Is it a stamp from an organization? A minimum amount of ties? An extra smile during enrollment?

If a Military Friendly University/College conducts classes on a military base (satellite) the University/College must keep up with current audio/visual equipment. The college I'm with has seriously allowed their audio/visual equipment to fall be the way-side. This to me shows a lack of interest in my educational success and/or hoarding of money generated by military students for other purposes other than serving its military students. Military students carry an equitable percentage of enrollment at my College and most of these students attend the majority of their classes on base. Yet the audio/visual equipment and dry-erase boards are terrible.

I feel disappointed that my major refused to count many of my military courses as credit towards my major when the courses I took in the military were either equal to or far beyond any training that the University offers within its courses.

I have nothing but great things to say. The staff, fellow veterans, professors and other students are great. It is a relatively small school, so it is easy to make friends who share the same degree path. 
I honestly did not know that ASU was considered a "Military Friendly University." I guess I'm glad to hear that but it would be great if it felt that way. My experience with anything military-related has been, for lack of a better term, 'meh'. Neither here nor there.

I incredibly dislike the faculty here.

I liked to get info about things that I did not know.

Instructors that have prior military experience are a great addition for the students as well as the university.

I really felt as part of the university from day one.

I saw many uniforms.

It's a great place for veterans.

It's really a non-factor. I exhausted my military bene's before I ever got to ASU. ASU then took all those credits but it didn't help me towards my degree AT ALL, apparently, because I still have to go a FULL 3 YEARS (maybe even more than that) and was already a Junior coming in. I looked at my program and there's probably no other way. So if I want any credit, for those credits, I would probably have to go back and complete ANOTHER DEGREE in communications. Then I have 2 degrees. Would that make me any more employable? Good question. Does my vet status help? Probably not.

It has been a positive experience.

I think that ASU - Havasu could become an excellent campus for military and disabled students. It's just going to require time and building the systems. It's a new campus - only 2 years in operation with only 150 or so students so far. If an organization took it upon themselves to invest some time they could have great success in setting up a specialized network, the campus is a blank slate right now.

It is really all what you make of it. If you want to be alone then you will be alone. If you want to get involved and be part of things going on around campus then you can. It is really up to each individual person. I have a friend going to a different college that has done well in school, but has struggled socially. I have joined a couple of groups and really immersed myself in the college culture. This has made a big difference for me personally. Even if this wasn't a military friendly school I think I would do alright.

I would like to see ASU get more involved in the Veteran's lives.

I would say there is adequate outreach to veterans, it's just difficult to reach people who do not want to ask for help. 
Just like other students, military veterans will get as much out of school as they put into it. Most student veterans I've encountered have been more mature and harder working than the average student.

Just wished we had an orientation for the veterans and contact info to ask for help when needed.

Most veterans, including myself, do not require support and services and adjust to academic life just fine. We also don't like being singled out as if we do require extra assistance. We have families and responsibilities, and would prefer to just go to class and go home. $99 \%$ have no interest whatsoever in campus activities and would appreciate if everyone would quit telling us to "join in and participate in campus life". We already have lives! I just want it to be easy to get my education benefits, which it was at WVSU. Other than that, I just want to be treated like any other person trying to get their degree.

My university got a new President last year. Since then I've seen a trend towards making this a Veteran friendly campus. However, much work needs to be done.
$\mathrm{N} / \mathrm{A}$
N/A
N/A
$\mathrm{N} / \mathrm{a}$
N/A
$\mathrm{N} / \mathrm{A}$
No
no
No
No
No
No
No
no
no
No
No
No
No
no
No 


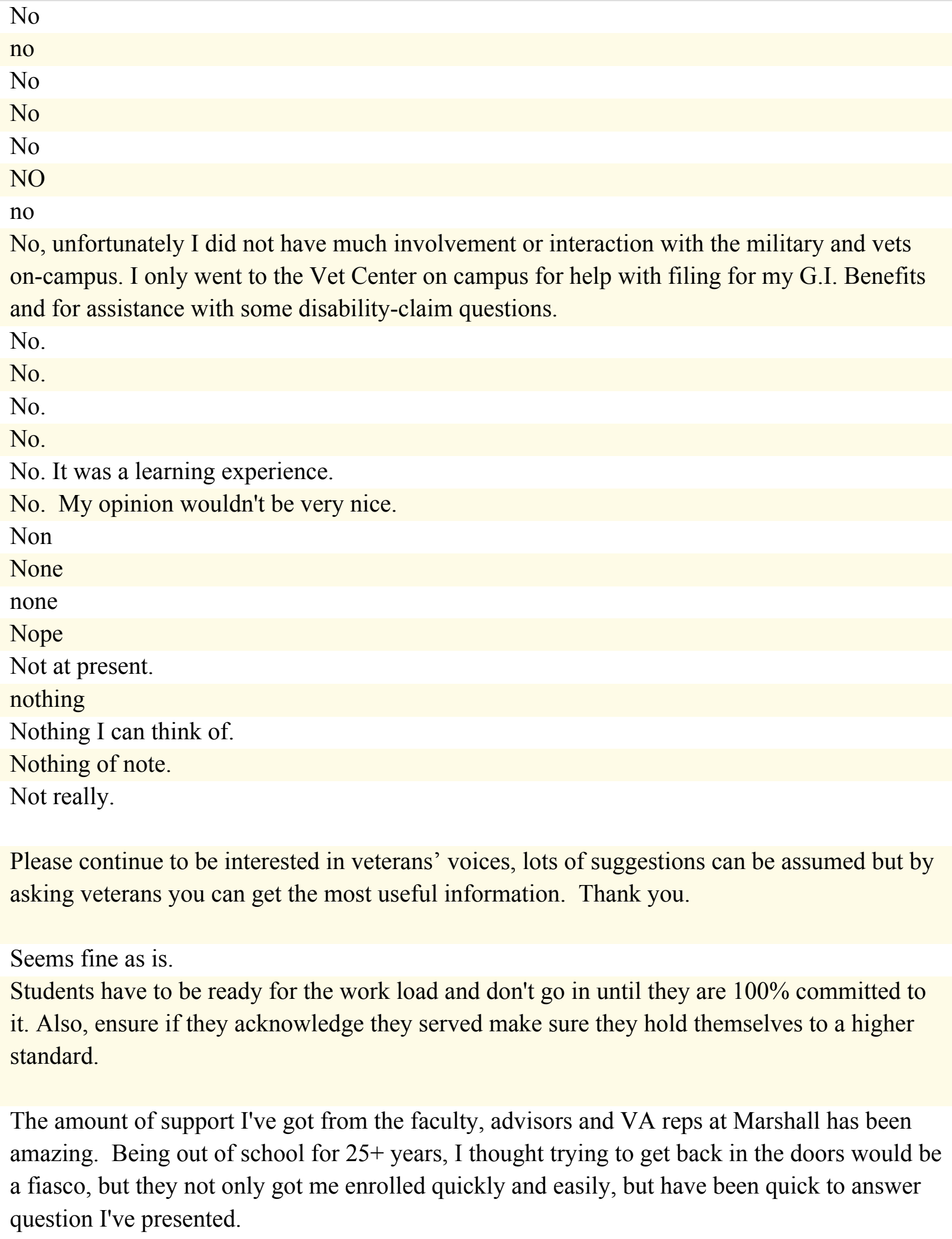

Please continue to be interested in veterans' voices, lots of suggestions can be assumed but by asking veterans you can get the most useful information. Thank you.

Seems fine as is.

Students have to be ready for the work load and don't go in until they are $100 \%$ committed to it. Also, ensure if they acknowledge they served make sure they hold themselves to a higher standard.

The amount of support I've got from the faculty, advisors and VA reps at Marshall has been amazing. Being out of school for $25+$ years, I thought trying to get back in the doors would be a fiasco, but they not only got me enrolled quickly and easily, but have been quick to answer question I've presented. 
The convenience of online courses have made it possible to work full time and complete courses toward a degree.

The military prepared me for college. Before I joined, I was lazy and unfocused. Now I have the drive and determination to complete anything put before me. No amount of counseling or support groups can give you the determination that exposure to adversity and prolonged hardships can provide.

The need for Veteran Mentors.

The only negative thing is that some online courses aren't taught on line a lot. It makes it difficult to find classes to take that I haven't taken yet.

There are resources for the military here and I can get all my questions answered if I have them but I don't feel as though the military really has a presence on this campus.

There have not been any military individuals I have met which I would prefer to meet others who have served along with me.

There are not any military veteran functions which I would be highly interested in. There is a lot of helpful information for veterans at this school.

There must be more one on one contact with Active military students, as well as veterans about our challenges with college. The military is night and day when compared to college. Many older students have trouble with the curriculum and instructors that go unnoticed. The instructors do their best but many of us have no one who can speak for us to someone at the campus who understands our plight.

The Staff, Veterans Center, and Professors at boring class. Have campuses on all the bases are top notch. Never a aiding Service members, Veteran, Military Retirees and family member in their quest for higher education.

The VA center on campus is great. Other than that, most of the stuff in this survey is ridiculous but that is my opinion. That is not to be interpreted as though I am not grateful for the resources here in campus for veterans. I think that in the future when formulating questions for a survey regarding military personnel/ veterans you should review these questions with a current veteran that is attending one of these military friendly colleges. By doing so I think you would get an accurate analysis of whatever it is that you seek.

They give out our names and emails way too freely. 
This was a little difficult to answer given that I was just accepted to the program. My experience in llinois was positive, both with the financial support and the academic coursework. I approached education like I did my time in the service - it's my job and I take it seriously.

Failure would reflect poorly upon me and those who believed in me.

Veteran services are there to help you succeed, they are more than understanding personal and academic struggles to help you in any way possible.

When Professors/Instructors understand military students and their common hardships when attending school.

WVU is NOT a military friendly university. 